\title{
CHRISTIANE SCHULTZ
}

\section{Condições da cóclea em pacientes oncológicos: opções na reabilitação auditiva}

Tese apresentada à Faculdade de Medicina da Universidade de São Paulo para obtenção do título de Doutor em Ciências

Programa de Otorrinolaringologia

Orientadora: Profa Dra . Maria Valéria Schmidt Goffi-Gomez

Co - Orientador : Prof Dr. Luiz Paulo Kowalski

Versão Corrigida

(Resolução CoPGr 6018/11 de 01 de novembro de 2011. A versão original está disponível na Biblioteca da FMUSP)

SÃO PAULO 
Dados Internacionais de Catalogação na Publicação (CIP)

Preparada pela Biblioteca da

Faculdade de Medicina da Universidade de São Paulo

Creprodução autorizada pelo autor

Schultz, Christiane

Condiçōes da cóclea em pacientes oncológicos :

opçōes na reabilitação auditiva / Christiane Schultz.

-- Săo Paulo, 2019.

Tese (doutorado)--Faculdade de Medicina da

Universidade de Săo Paulo.

Programa de Otorrinolaringologia.

Orientadora: Maria Valéria Schmidt Goffi Gomez.

Descritores: 1.Audiologia 2.Cisplatino

3. Quimioterapia 4.Perda auditiva 5. Cóclea 6. Aparelho

auditivo 7. Implante coclear

$\mathrm{USP} / \mathrm{FM} / \mathrm{DBD}-223 / 19$

Responsável: Erinalva da Conceiçăo Batista, CRB-8 6755 
Comitê de Ética do HC FM-USP

CAAE: 45553215.6 .0000 .0065

Parecer no. 1.222.109

Data: 10/09/2015

Comitê de Ética do A C Camargo Cancer Center

CAAE: 65086017.9 .3002 .5432

Parecer no. 2.018.576

Data: $17 / 04 / 2017$ 


\section{DEDICATÓRIA}

Dedico este trabalho aos pesquisadores, sobretudo no Brasil.

Fazer pesquisa é muito difícil, mas sem as idéias e a determinação dos pesquisadores, não haveria desenvolvimento.

Não desistam, não desanimem, acreditem no impossível e façam milagres acontecer! 


\section{AGRADECIMENTOS}

Ao meu esposo Antonio Luiz Basile, meu companheiro de todas as horas. Obrigada por estar comigo, obrigada compartilhar conquistas e dificuldades comigo. Obrigada pelo apoio e compreensão.

Aos meus pais Aurea Schultz (in memoriam) e Mauro Schultz Sobrinho (in memoriam). Obrigada por serem meus pais. Obrigada por me educarem e pelo amor que recebi. Me tornei a pessoa que sou hoje, graças á vocês. Sinto muito a falta de vocês, mas sei que estão sempre por perto.

Aos meus tios Cecilia Maria Fagioli e Claudio Pessoa Cavalcante (in memoriam). Pelo suporte emocional e financeiro. Pelo ombro amigo, pelo abraço. Por acreditarem em mim e na mimha profissão.

Á Fga Dra. Patricia Helena Pecora Liberman, minha chefe, minha amiga, minha confidente. Obrigada pelo apoio, pela amizade, pela compreesão, pela ajuda. Se não fosse você, não teria tido a oportunidade de trabalhar no lugar onde realmente me encontrei profissionalmente.

Aos pacientes oncológicos, por me ensinarem o real valor da vida e como vale a pena lutar por ela. Ser feliz, superar obstáculos e dificuldades e seguir em frente agradencendo.

Ao grupo de implante coclear do HCFMUSP, meu muito obrigada a cada um de vocês, que me acolheram, me fizeram sentir parte desta família. Tudo o que sei sobre implantes aprendi nesta casa com a ajuda de vocês. Que continuem fazendo este lindo trabalho, com muito empenho e dedicação aos pacientes.

Ás professoras do Instituito de matemática e estatística da Univesridsade de São Paulo, Denise Botter e Monica Sandoval, pela análise estatística dos dados.

Ao Professor Dr. Afonso Celso Monte Alegre (in memoriam) mestre querido, muito obrigada por me permitir fazer parte de teu consultório, da tua vida profissional.

Ao Dr. Sami Liberman, pela revisão dos dados estatísticos.

Ao Professor Dr. Bernardo Liberman, pela revisão cuidadosa do texto e das referências bibliográficas e por ser um paciente tão querido e especial.

Ao Professor Doutor Luiz Paulo Kowalski, exemplo de sabedoria e conhecimento e pela busca incansável pelo aprimoramento profissional.

Á Professora Dra. Maria Valéria Schimdt Goffi Gomez, orientadora de todos os aspectos da minha vida! Inspiração! Exemplo de profissional competente, dedicada e humana! Gratidão eterna por toda a ajuda e incentivo profissional. Que você sempre seja essa luz que brilha e que faz diferença na vida de quem está perto de ti! Te desejo muito mais sucesso e felicidade!

Muito Obrigada ! 
"Não estacione sua alma em espaços onde não cabem seus sonhos.

Jamais estacione sua alma, ela precisa de movimento. Jamais estacione seus sonhos, eles precisam de liberdade. Jamais estacione sua esperença, ela precisa de espaço. Jamais estacione sua alegria, ela precisa de ação. Jamais se estacione, onde não te cabe, não se contenha, não se permita ser contido. Somos alma em evolução, somos o caminho que ensina, somos a luz que sempre vence a escuridão. Jamais estacione!!" Dra. Roberta França - Geriátra 
Esta tese está de acordo com as seguintes normas, em vigor no momento desta publicação:

- Referências: adaptado de International Committee of Medical Journals Editors (Vancouver).

- Universidade de São Paulo. Faculdade de Medicina. Divisão de Biblioteca e Documentação. Guia de apresentação de dissertações, teses e monografias. Elaborado por Anneliese Carneiro da Cunha, Maria Julia de A. L. Freddi, Maria F. Crestana, Marinalva de Souza Aragão, Suely Campos Cardoso, Valéria Vilhena. 3a ed. São Paulo: Divisão de Biblioteca e Documentação; 2011.

- Abreviaturas dos títulos dos periódicos de acordo com List of Journals Indexed in Index Medicus. 


\section{LISTA DE ILUSTRAÇÕES}

\section{LISTA DE QUADROS}

\section{LISTA DE TABELAS}

\section{RESUMO}

\section{ABSTRACT}

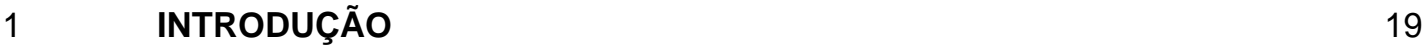

2 REVISÃO DE LITERATURA 29

2.1 ZONAS MORTAS COCLEARES 29

2.2 REABILITAÇÃO AUDITIVA NAS PERDAS AUDITIVAS EM RAMPA 35

2.2.1 USO DA LIMITAÇÃO DE FREQUÊNCIAS NAS PRÓTESES AUDITIVAS

2.2.2 IMPLANTE COCLEAR HÍBRIDO OU ESTIMULAÇÃO ELETROACÚSTICA 43

2.3 MAPEAMENTO TONOTÓPICO CORTICAL APÓS PRIVAÇÃO SENSORIAL 48

3 OBJETIVOS 55

$4 \quad$ MATERIAL E MÉTODO

5 RESULTADOS 66

6 DISCUSSÃO 79

7 CONCLUSÃO 91

8 ANEXOS 93

Anexo A - Parecer consubstanciado com aprovação pelo CEP FMUSP

Anexo B - Parecer consubstanciado com aprovação pelo CEP AC CAMARGO

Anexo C - Termo de Consentimento Livre e Esclarecido

Anexo D - Termo de Consentimento Livre e Esclarecido

Anexo E - Hearing Handicap Inventory for the Adult

Anexo F - Hearing Handicap Inventory for the Elderly

Anexo G - Lista de Frases

Anexo $\mathrm{H}$ - Lista de monossílabos

Anexo I - Ficha técnica prótese auditiva Naída III SP

Anexo J - Exemplo de verificação das próteses auditivas

9 REFERÊNCIAS BIBLIOGRÁFICAS 116

$\begin{array}{lll}10 & \text { APÊNDICES } & 129\end{array}$

Apêndice A - Limiares auditivos em campo livre, nas três situações avaliadas, sem próteses auditivas, com próteses auditivas com limitação de frequências e sem limitação de frequências. 
LISTA DE ABREVIATURA E SIGLAS

\begin{tabular}{|c|c|}
\hline ABR & Auditory Brainstem Response \\
\hline AGC & Automatic Gain Control \\
\hline APHAB & Abbreviated Profile for Hearing Aid Benefit \\
\hline AUS & Ausente \\
\hline BDI & Beck Depression Inventory \\
\hline CDDP & Cisplatina \\
\hline CCE & Célula Ciliada Externa \\
\hline $\mathrm{CCl}$ & Célula Ciliada Interna \\
\hline$d B$ & Decibel \\
\hline dBNA & Decibel Nível de Audição \\
\hline dBNPS & Decibel Nível de Pressão Sonora \\
\hline DNA & Ácido Desoxiribonucleico \\
\hline EAS & Estimulação eletro-acústica \\
\hline ERB & Equivalent Retangular Bandwidth \\
\hline fe & Frequência de Início da Zona Morta Coclear \\
\hline GHABP & Glasgow Hearing Aid Benefit Profile \\
\hline HHIA & Hearing Handicap Inventory for the Adults \\
\hline HHIE & Hearing Handicap Inventory for the Elderly \\
\hline HMS & Hearing Measurement Scale \\
\hline $\mathrm{IOI}-\mathrm{HA}$ & International Outcome Inventory for Hearing Aids \\
\hline IPRF & Índice Porcentual de Reconhecimento de Fala \\
\hline JSQ & Judment of Sound Quality \\
\hline NS & Não Significante \\
\hline QI-AASI & Questionário Internacional de Aparelho de Amplificação Sonora Individual \\
\hline LRF & Limiar de Reconhecimento de Fala \\
\hline TEN & Threshold Equalizing Noise \\
\hline PTA & Pure Tone Average \\
\hline PTC & Psychophysical Tuning Curves \\
\hline PRES & Presente \\
\hline QI-AASI & Questionário Internacional - Aparelho de Amplificação Sonora Individual \\
\hline RNA & Ácido Ribonucleico \\
\hline sABR & Speech Auditory Brainstem Responses \\
\hline SII & Speech Intelligibility Index \\
\hline STAI & State-Trait Aniety Inventory \\
\hline SSQ & Speech, Spatial and Qualities of Hearing Questionnaire \\
\hline SWPTC & Sweep Psychophysical tuning curves \\
\hline WDRC & Wide Dynamic Range Compression \\
\hline
\end{tabular}




\section{LISTA DE ILUSTRAÇÕES}

Figura 1- Modelo de circulação da cisplatina na cóclea. Breglio et al. (2017)

Figura 2 - Sistema eferente olivo coclear medial.

Figura 3 - Células ciliadas internas e externas.

Figura 4 - Zonas mortas cocleares.

Figura 5 - Curvas de limitação de frequências em uma prótese auditiva.

Figura 6- Limites audiológicos para os candidatos ao implante coclear híbrido ou estimulação eletro-acústica.

Figura 7. Fluxograma dos procedimentos envolvidos no estudo.

Figura 8 - Limiares auditivos em campo livre sem Próteses Auditivas 


\section{LISTA DE TABELAS}

$\begin{array}{ll}\text { Tabela } 1 \text { - Dados demográficos } & 67\end{array}$

Tabela 2 - Resultado do teste TEN para cada paciente 68

Tabela 3 - Medidas descritivas dos limiares auditivos com e sem próteses auditivas (em dB 69 $\mathrm{NA})$ por frequência (em Hz) em ambas as orelhas.

Tabela 4 - Medidas descritivas dos limiares auditivos com próteses auditivas (em dB NA) por 70 frequência (em Hz) na orelha direita nas condições estudadas

Tabela 5 - Medidas descritivas dos limiares auditivos com próteses auditivas (em dB NA) por 71 frequência $(\mathrm{em} \mathrm{Hz})$ na orelha esquerda nas condições estudadas

Tabela 6 - Medidas descritivas da porcentagem de acertos (\%) para os testes monossílabos no silêncio, monossílabos no ruído com relação sinal/ruído $=0 \mathrm{~dB}(\mathrm{SNR}=0 \mathrm{~dB})$, frases no silêncio e frases no ruído com relação sinal/ruído $=0 \mathrm{~dB}(\mathrm{SNR}=0 \mathrm{~dB})$, em ambas as orelhas, com e sem próteses auditivas

Tabela 7 - Medidas descritivas da porcentagem de acertos (\%) para os testes monossílabos no silêncio, monossílabos no ruído com relação sinal/ruído $=0 \mathrm{~dB}(\mathrm{SNR}=0 \mathrm{~dB})$, frases no silêncio e frases no ruído com relação sinal/ruído $=0 \mathrm{~dB}(\mathrm{SNR}=0 \mathrm{~dB})$, na orelha direita nas duas condições de amplificação estudadas

Tabela 8 - Medidas descritivas da porcentagem de acertos (\%) para os testes monossílabos no silênco, monossílabos no ruído com relação sinal/ruído $=0 \mathrm{~dB}(\mathrm{SNR}=0 \mathrm{~dB})$, frases no silêncio e frases no ruído com relação sinal/ruído $=0 \mathrm{~dB}(\mathrm{SNR}=0 \mathrm{~dB})$, na orelha esquerda nas duas condições de amplificação estudadas

Tabela 9 - Medidas descritivas da variável HHIA por condição 74

Tabela 10 - Medidas descritivas da variável nota por condição 74

Tabela 11 - Valor do Speech Inteligibility Index (em \%) para sons de entrada de 55, 65 e 7575 dBNA, respectivamente, nas condições sem e com limitação de frequências por orelha e valor do datallogin com média de uso em horas por dia

Tabela 12 - Número de pacientes que optaram pela programação com e sem limitação de 75 frequências acionada

Tabela 13 - Valor da porcentagem de acertos do reconhecimento de frases e monossílabos 76 (em \%) no silêncio sem AASI apresentados a 60 dBNA em campo livre, em condição binaural

Tabela 14 - Valor da porcentagem de acertos do reconhecimento de monossílabos (em \%) 77 com AASI apresentados a $60 \mathrm{dBNA}$, nas duas condições estudadas, para a identificação da indicação do implante coclear híbrido ou estimulação eletroacústica em cada uma das orelhas 


\section{RESUMO}

Schultz C. Condições da cóclea em pacientes oncológicos: opções na reabilitação auditiva [tese]. São Paulo: Faculdade de Medicina, Universidade de São Paulo; 2019.

Os pacientes oncológicos que fazem uso de derivados da platina apresentam como sintoma da ototoxicidade a diminuição da acuidade auditiva principalmente em frequências altas. As perdas auditivas de configuração descendente podem ser de tal grau que causem prejuízo importante da compreensão da fala, possivelmente pela presença de zonas mortas na cóclea. O conceito de "zonas mortas cocleares", proposto por Moore (2004), define que existem regiões na cóclea, nas quais as células ciliadas internas estão lesadas, inativas ou ausentes, e os neurônios que inervam essas regiões estariam inativos ou degenerados. Nessa situação, a amplificação dada pelas próteses auditivas não beneficiaria o paciente, pela falta do aporte sensorial coclear para a transdução do som. Para alguns desses casos, existe a opção do implante coclear híbrido ou estimulação eletro-acústica. Este estudo tem por objetivo identificar a frequência de ocorrência de pacientes com perdas auditivas neurossensoriais, com configuração descendente em rampa, com presença de zonas mortas cocleares após o tratamento oncológico que se beneficiam do uso de próteses auditivas prescritas para perdas em rampa; e a frequência de ocorrência de pacientes que sejam candidatos à cirurgia com o implante coclear híbrido. Foram convidados a participar do estudo todos os pacientes acompanhados no Departamento de Audiologia do A.C. Camargo Cancer Center, atendidos entre maio de 2017 e dezembro de 2018, que apresentaram perda auditiva descendente em rampa, ou seja, limiares audiométricos iguais ou superiores a $70 \mathrm{dBNA}$ a partir de $2000 \mathrm{~Hz}$ ao final do tratamento oncológico. Foram excluídos pacientes com malformação de orelha externa, orelha média ou orelha interna; tumores envolvendo o sistema auditivo, periférico ou central, cirurgia otológica prévia e pacientes incapazes de compreender ou realizar a avaliação proposta. Os procedimentos envolveram o teste TEN (TEN Threshold Equalizing Noise) para identificação de zonas mortas cocleares e o questionário HHIA (Hearing Handicap Inventory for Adults), ou o questionário 
HHIE (Hearing Handicap Inventory for Elderly), dependendo da idade do paciente, ambos adaptados ao português. Com a identificação da perda auditiva e a presença das zonas mortas cocleares, o paciente foi convidado ao processo de adaptação e experiência domiciliar com próteses auditivas convencionais, considerando a prescrição do médico otorrinolaringologista. Foram testados dois programas, com e sem compressão de frequências, para experiência domiciliar durante, pelo menos, 15 dias cada um. Após o período de experiência, foram realizados testes com cada programação para avaliar o benefício de cada programa, incluindo audiometria em campo livre e testes de reconhecimento de fala no silêncio e no ruído com relação sinal-ruído (SNR) de OdB. Ao final da avaliação, o paciente definiu sua preferência, por meio de uma nota de zero a dez. A ordem de apresentação dos programas, com e sem a compressão de frequências, foi randomizada (www.randomizer.org) e o paciente enceguecido sem saber qual programação estava experimentando. Caso o paciente não demonstrasse benefício com as próteses em nenhum dos programas, foi proposta a avaliação e explicação do procedimento do implante coclear híbrido. Se o benefício com o uso de próteses auditivas convencionais foi identificado, seja pelos resultados da avaliação ou pelo julgamento subjetivo do paciente, o processo de teste das próteses foi finalizado com a doação pelo Sistema Único de Saúde, ou foi dada a oportunidade de adquirir os aparelhos.

Descritores: Audiologia; Cisplatino; Quimioterapia; Perda Auditiva; Cóclea; Aparelho auditivo; Implante Coclear. 


\section{ABSTRACT}

Schultz C. Cochlear conditions in cancer patients: auditory rehabilitation options [thesis]. São Paulo: "Faculdade de Medicina, Universidade de São Paulo"; 2019.

Oncological patients treated with platinum agents may present hearing loss, especially at high frequencies, as a symptom of ototoxicity. Descending hearing loss may be of such degree that may significantly affect speech recognition, possibly due to the presence of dead regions in the cochlea. The concept of cochlear dead regions, proposed by Moore (2004), defines that there are regions in the cochlea, in which the inner hair cells are damaged, inactive or absent, and the neurons that innervate these regions would be inactive or degenerated. In this situation, the amplification of conventional hearing aids would hardly benefit the patient, considering the lack of hair cells for the sound transduction. This study aims to identify the frequency of occurrence of patients with steep slope sensorineural hearing loss and cochlear dead regions after the oncological treatment who benefit from hearing aids; and the frequency of occurrence of patients who are candidates for hybrid cochlear implant surgery. All patients routinely acompanied in the Audiology Department of the A.C. Camargo Cancer Center between May 2017 and December 2018 and who had steep slope hearing loss, with thresholds equal to or worse than $70 \mathrm{dBHL}$ at $2000 \mathrm{~Hz}$ after treatment, were invited to participate in the study. Patients with malformation of the outer, middle or inner ear; tumors involving the peripheral or central auditory system, previous otologic surgery and patients unable to follow the instructions for the evaluation were excluded. The procedures involved the TEN test (Threshold Equalizing Noise) for identification of cochlear dead regions and the Hearing Handicap Inventory for Adults (HHIA), or the Hearing Handicap Inventory for Elderly (HHIE), depending on the age of the patient, both adapted to Portuguese. With the identification of hearing loss and the presence of cochlear dead regions, the patient was invited to the process of hearing aid adaptation and home experience, considering the prescription of the otorhinolaryngologist. Two programs, with and without frequency compression, were tested for home experience for at least 15 days each. After the trial period, 
tests were performed with each program to evaluate the benefit of each program, including free field audiometry and speech recognition tests in silence and in noise with $0 \mathrm{~dB}$ of signal to noise ratio (SNR). At the end of the evaluation, the patient defined his preference by means of a grade from zero to ten. The order of presentation of the programs with and without frequency compression, was randomized (www.randomizer.org) and the patient was blinded, not knowing which programming was on. If the patient did not show benefit with the hearing aids with any of the programs, the evaluation and explanation of the electro-acoustic stimulation or hybrid cochlear implant procedure was presented. If the benefit with the use of conventional hearing aids was identified, either by the evaluation results or by the subjective judgment of the patient, the evaluation process was finalized with the donation by the national Health Sistem (Sistema Único de Saúde), or it was offered the option of acquisition.

Descriptors: Audiology; Cisplatin; Chemotherapy; Hearing Loss; Cochlea; Hearing Aids; Cochlear Implantation. 
1 INTRODUCÃO 


\section{INTRODUÇÃO}

A Cisplatina é a principal droga utilizada no tratamento quimioterápico de diferentes tumores sólidos, é a droga antineoplásica mais ototóxica conhecida (Rademaker-Lakhai et al., 2006) e ainda não existe intervenção terapêutica que possa prevenir a ocorrência de otoxicidade (Esfahani-Monfared et al., 2017).

Seu mecanismo de ação leva à inibição da síntese do DNA e à supressão da transcrição do RNA levando á apoptose celular.

$\mathrm{Na}$ cóclea acontece um acúmulo de maior concentração na estria vascular, que é a responsável pela manutenção da endolinfa e acredita-se que a morte das células ciliadas seja secundária à impregnação da endolinfa. $\mathrm{A}$ cóclea parece ter pequena capacidade de eliminar os derivados da platina, permanecendo em seu interior por anos. A figura 1 ilustra o esquema de (circulação da cisplatina no órgão de Corti.Breglio et al., 2017).

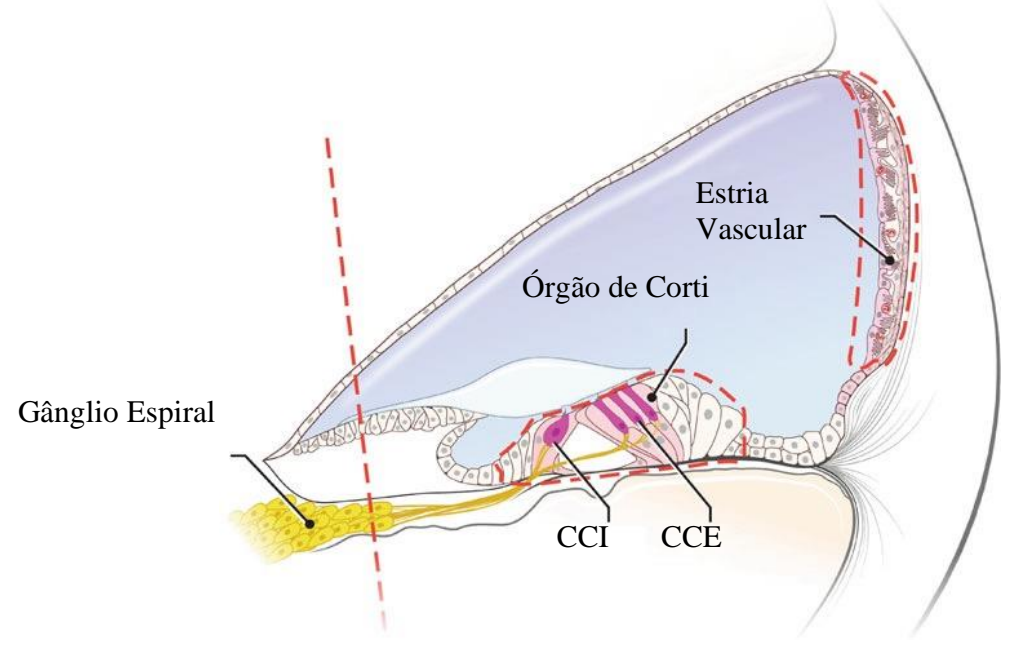

Figura 1. Modelo de circulação da cisplatina na cóclea. Breglio et al. (2017) 
A ototoxicidade induzida pela cisplatina altera o sistema antioxidante celular, pois as vias de detoxificação, os níveis de glutationa e a atividade de enzimas antioxidantes ficam reduzidas, levando à peroxidação lipídica instalando a toxicidade celular que em última instância causa apoptose celular, levando a célula à morte (Rybak 1999, Hyppolito et al., 2006, Mukherjea \& Rybak, 2011). Alguns estudos têm demonstrado que os mecanismos citotóxicos da cisplatina incluem dano do DNA mitocondrial e formação de radicais livres (Mukherjea \& Rybak, 2011). Os pacientes que fazem uso de derivados da platina apresentam, como principal sintoma da ototoxicidade, a diminuição da acuidade auditiva.

A radioterapia em região de cabeça e pescoço pode causar alterações auditivas transitórias ou permanentes. As perdas auditivas neurossensoriais decorrentes deste tratamento parecem resultar da perda das células ciliadas, sobretudo no giro basal da cóclea. A etiologia está relacionada a uma insuficiente vascularização, sobretudo no gânglio espiral, levando à progressiva degeneração e atrofia das estruturas sensoriais da orelha interna, fibrose e até ossificação dos fluídos da orelha interna (Jereczek-fossa et al., 2003). O componente neurossensorial parece ser causado por doses tóxicas totais acima dos 6000 cGY (Zurr et al., 2007) ou na cóclea acima de 1200 cGy (Linksey e Johnstone, 2003).

A ototoxicidade se manifesta como uma perda auditiva sensorioneural permanente, bilateral, simétrica e inicialmente em frequências altas (Hyppolito et al., 2005, Rademaker-Lakhai et al., 2006; Nitz et al., 2013; EsfahaniMonfared et al., 2017). A ocorrência de perda auditiva varia entre 20\% e $60 \%$ (Liberman, 2005; Zuur et al., 2007; Katzenstein et al., 2009), em função das diferenças nas populações estudadas ou dependendo da classificação de perda auditiva adotada (Schultz et al., 2009).

Estudos mais recentes demonstram que a perda auditiva pode continuar a progredir ou piorar mesmo anos após o final do tratamento e podem atingir as baixas frequências (Bertolini et al., 2004; Einarsson et al., 2010), o que sugere a necessidade de acompanhamento audiológico por longo período, a fim de verificar e acompanhar as alterações e minimizar seu efeito 
na vida do paciente (Breglio et al., 2017). Qualquer perda auditiva dificulta ou impede a adequada condução do som ao sistema nervoso auditivo, implicando perda do conteúdo da mensagem e levando a uma comunicação insatisfatória, trazendo consequências sociais e, por vezes, emocionais aos indivíduos (Schultz, 2007). Na impossibilidade de evitar a perda, é necessário diagnóstico preciso e tratamento médico e fonoaudiológico adequado, visando proporcionar uma melhor qualidade de vida e diminuição de suas limitações.

A configuração das perdas auditivas por ototoxicidade geralmente é em rampa acentuada (Skinner, 2004; Rybak et al., 2009; Schultz et al., 2010; Einarsson et al., 2010; Liberman et al., 2005), e, com isso, a queixa principal encontrada é a dificuldade de compreender a fala em ambiente ruidoso (Liberman et al., 2004), é o fato de "ouvir mas não entender" (Schochat, 1997). Nestas perdas, há preservação dos limiares auditivos para as frequências baixas e queda nos limiares auditivos nas frequências de fala e altas. $O$ reconhecimento de fala depende da extensão da perda auditiva, do acesso às frequências importantes para o reconhecimento das pistas acústicas de fala, do nível de sensação ou de distorção do indivíduo (Ching et al., 1998). Perdas auditivas neurossensoriais descendentes podem levar a dificuldades na discriminação de fala, desde moderada até muito pobre (Magalhães et al., 2007), podendo apresentar uma frequência de resultados do índice de reconhecimento de fala à viva voz de somente $26,3 \%$ (De Andrade et al., 2016).

Dada a necessidade de oferecer a esses pacientes o acesso às pistas acústicas das frequências altas, o uso de próteses auditivas está indicado. Entretanto, por se tratar de uma perda importante geralmente limitada às frequências altas, o processo de adaptação nestes indivíduos é desafiador, pois ao mesmo tempo em que necessitam de amplificação em frequências altas, não pode haver amplificação nas baixas frequências. A literatura reporta que a falta de benefício com a amplificação nas frequências altas está correlacionado com a extensão do dano às células ciliadas (Baer et al., 2002).

As perdas auditivas podem ter sido causadas por lesões, tanto nas células ciliadas externas quanto nas células ciliadas internas, no órgão de 
Corti. A figura 3 mostra uma foto das células ciliadas internas e externas. As células ciliadas externas têm motilidade e têm como função amplificar a onda viajante (Landegger et al., 2016). O dano somente nestas células externas afeta o mecanismo ativo da cóclea e resulta em uma reduzida sensitividade a sons fracos, reduzida seletividade de frequências, área dinâmica reduzida e aumento dos limiares auditivos (Moore, 2001). Dados fisiológicos em animais mostram que a quantidade de perda auditiva, causada somente por lesão às células ciliadas externas, pode chegar a $50 \mathrm{~dB}$ nas frequências baixas e a 65 dBNA nas altas frequências (Ruggero et al., 1997). As células ciliadas internas são o principal órgão sensorial da orelha interna, elas são os transdutores da cóclea, sua função é converter o estímulo mecânico em pulso elétrico, que depois será processado pelos neurônios do gânglio espiral (Landegger et al., 2016). Quando a lesão atinge as células ciliadas internas, os limiares auditivos serão superiores a 65 dBNA (Ruggero et al., 1997). E limiares absolutos superiores a 70 dBNA estão fortemente relacionados à presença de zonas mortas cocleares (Moore, 2001). O sistema olivococlear eferente medial é responsável por inibir as contrações rápidas das células ciliadas externas e têm papel na performance da captação do sinal auditivo em presença de ruído de fundo, aumentando a sensibilidade à fonte sonora na presença de ruído competitivo, como ilustrado na figura 2 (Breuel ML., et al.,2001).

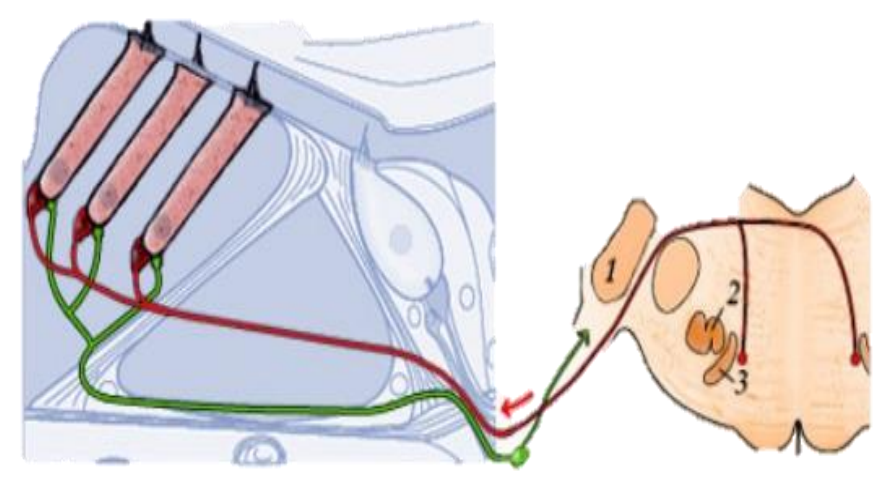

Figura 2. Siatema eferente olivo coclear medial. Fonte: https://pt.slideshare.net/yasnafox/viaauditiva-aferente-y-eferente/ 


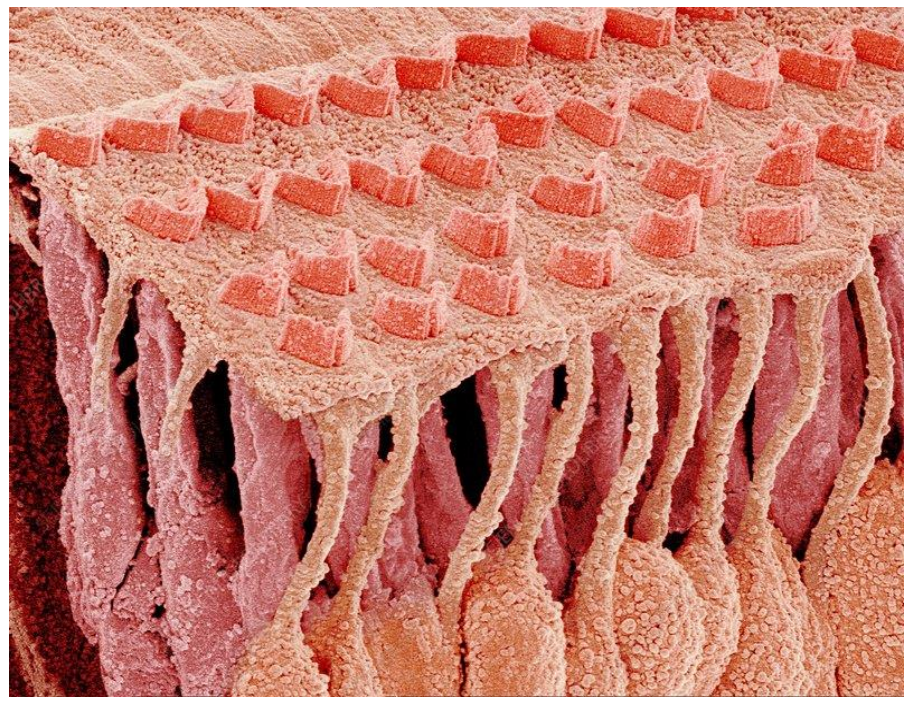

Figura 3. Células ciliadas internas e extenas

Fonte https://www.sciencephoto.com/media/395497/view

Segundo Moore (2004), o conceito de "Zonas Mortas cocleares" é antigo, com a descrição de Troland (1929) como lacunas "lacunae". Schuknecht (1955) e Schuknecht and Gacek (1993) estudaram ossos temporais relatando o dano às células ciliadas internas, externas ou aos neurônios correspondentes e correlacionando com o "encolhimento " ou ausência da estria vascular. Em 1998, Moore \& Glasberg definem que existem regiões na cóclea nas quais as células ciliadas internas estão lesadas, inativas ou ausentes, e os neurônios que inervam essas regiões estariam inativos ou degenerados. Deste modo, um tom puro que produza um pico de vibração nesta região, será detectado em outro local na cóclea (este conceito foi descrito como off place ou off frequency listening). O tom será detectado onde a quantidade de vibração da membrana basilar for menor mas cujas células ciliadas internas e/ou os neurônios correspondentes estejam saudáveis e funcionando com maior eficiência (Moore, 2001).

Sabe-se que não é possível definir a presença de zonas mortas cocleares somente pelo audiograma, nem medir sua extensão, mas existem dados sugestivos da sua presença.

Nos casos de zona morta coclear em frequências baixas, normalmente 0 paciente apresenta rebaixamento dos limiares auditivos nestas frequências 
mas com limiares auditivos dentro da normalidade em frequências médias e altas. Isto porque o tom puro não será detectado pelos neurônios que enervam a região apical da cóclea, porque as células ciliadas internas estão mortas. Mas este tom puro será audível quando produzir uma excitação suficiente da membrana basilar e, através da dispersão da excitabilidade será percebido pela região basal da cóclea. Limiares auditivos entre 40 a 50dBNA em frequências baixas com limiares auditivos normais em frequências médias e altas ou limiares auditivos entre 40 a 50dBNA nas frequências baixas, com perda auditiva de grau leve nas frequências médias e limiares auditivos normais em frequências altas, sugerem presença de zonas mortas cocleares em frequências baixas (Moore, 2001; 2004). Moore (2007) encontrou uma prevalência de $2,3 \%$ de presença de zonas irresponsiva cocleares apenas em baixas frequências.

As zonas mortas cocleares em frequências altas caracterizam-se por perdas auditivas neurossensoriais, com audiogramas em rampa, e limiares auditivos que pioram bruscamente à medida que a frequência aumenta. Estão associadas com perdas auditivas de grau severo a profundo. As frequências que estão na parte íngreme do audiograma refletem a dispersão de excitabilidade da membrana basilar, onde as células ciliadas internas ainda estão íntegras. Audiogramas com perda auditiva maior do que 90dBNA em frequências altas, ou com limiares aumentando bruscamente, mais do que $50 \mathrm{~dB}$ por oitava são indicativos fortes da presença de zonas mortas cocleares em frequências altas. A figura 4 ilustra zonas mortas cocleares. O critério sugestivo da presença de zona morta, é perda auditiva com limiares superiores a $70 \mathrm{~dB}$ em qualquer frequência (Moore, 2007). Moore (2007) encontrou prevalência de $41,9 \%$ de orelhas com presença de zonas mortas cocleares apenas em frequências altas e somente $1,8 \%$ de orelhas com presença de zonas mortas cocleares em frequências altas e baixas concomitantemente. 


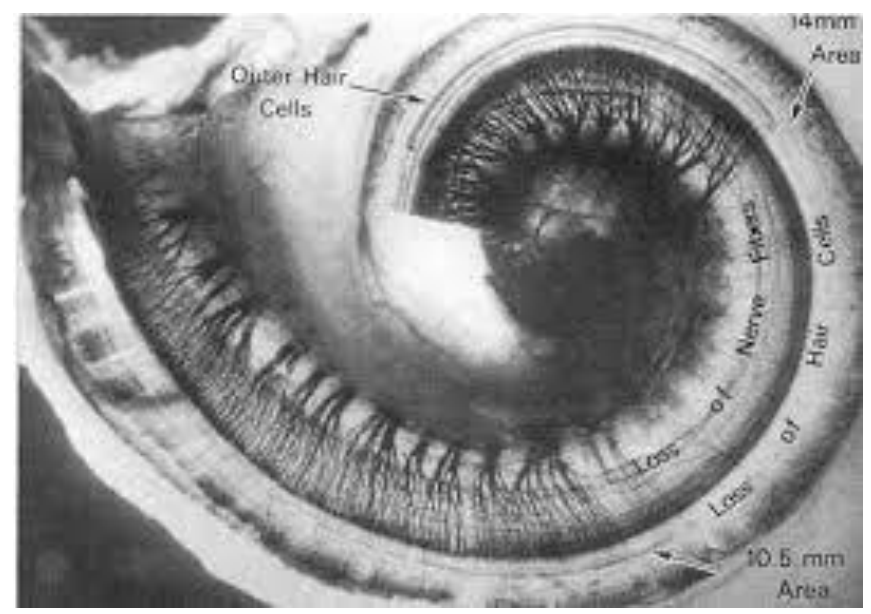

Figura 4. Zonas mortas cocleares Fonte: Cosmology Science News (disponível em http//www.cosmology.com)

Uma das funções mais importantes da audição é a possibilidade de compreender a fala. O som da fala é uma combinação complexa de frequências e de amplitudes (Einarsson et al., 2010) e a habilidade de reconhecer e de discriminar corretamente a fala após uma perda auditiva não pode ser avaliada corretamente somente através da audiometria tonal e vocal. Uma adequada resolução temporal depende da seletividade espectral e da seletividade de frequências feitas pelas células ciliadas internas (Moore, 2007).

Indivíduos com perda auditiva de grau severo podem não ouvir certos sons de fala, até que eles sejam apresentados em elevados níveis sonoros e isto pode representar um desafio para ajustar os aparelhos auditivos, pois nestes pacientes a área dinâmica da audição normalmente está reduzida, (Simpson et al., 2005).

A performance assim como o benefício com o uso de próteses auditivas em indivíduos com perda auditiva em frequências altas depende da audibilidade destes sinais mas também da capacidade individual de extrair informações úteis destes sinais audíveis (Glista et al., 2009). De modo que fornecer amplificação a pacientes com perda auditiva severa a profunda em altas frequências ainda continua a ser controversa entre diversos autores. Alguns estudos apontaram que prover audibilidade ou amplificação nestas frequências não se traduz em melhora da performance de compreensão de 
fala, uma vez que existe a necessidade do aporte sensorial coclear para a transdução do som, e nesses pacientes a região morta geraria pouca ou nenhuma informação útil à discriminação dos sons da fala (Ching et al. 1998; Gordo \& lório, 2007). Outros estudos demonstraram que fornecer informação acústica em frequências altas para estes pacientes melhora a compreensão de fala sobretudo em ambientes ruidosos (Moore, 2000; Cox, 2011).

A estabilidade das perdas auditivas por ototoxicidade nos permite oferecer aos pacientes oncológicos a mais variada opção de reabilitação auditiva, no entanto o tempo de privação sensorial deve ser considerado, de maneira que intervir precocemente deve ser sempre o ideal a ser perseguido.

A condição de não responsividade de cóclea nos conduzirá a escolher a melhor conduta para permititr a reabilitação de maneira mais personalizada possível.

Quanto às próteses auditivas, hoje existem dois recursos que visam ajudar na audibilidade de sons de frequências altas na presença de zonas mortas: a compressão e a transposição de frequências, comprimindo ou transportando sons de altas frequências para regiões de baixas frequências, tornando-os audíveis (Kuk et al., 2009). A figura 5 ilustra uma curva de limitação de frequências em uma prótese auditiva.

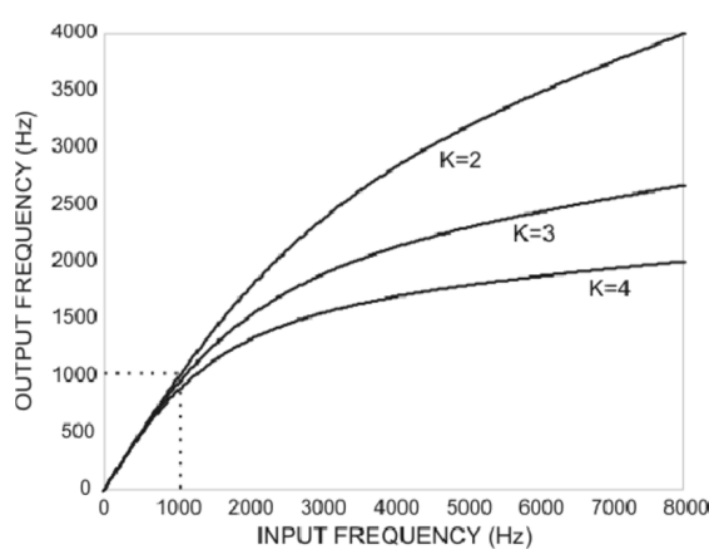

Figura 5. Curvas de limitação de frequências em uma prótese auditiva. Curvas de razão de limitação de frequências, no eixo das abscissas está identificada a frequência de entrada e no eixo das ordenadas estão identificadas as frequências de saída. $\mathrm{Na}$ amplificação com razão $\mathrm{K}$ $=2$, a frequência de entrada até $1 \mathrm{k} \mathrm{Hz}$ é amplificada como $1 \mathrm{kHz}$, e $6 \mathrm{kHz}$ é amplificada na faixa de $3 \mathrm{kHz}$; Na razão $\mathrm{K}=4$, a frequência de entrada de $6 \mathrm{kHz}$ corresponde a $2 \mathrm{kHz}$.

Fonte: Fraga et al. (2011) https://www.researchgate.net/figure/Input-output-frequencycompression-curves 
Outra opção de reabilitação auditiva, para os pacientes com audição residual em frequências baixas e perdas severas a profundas em frequências altas, é a estimulação eletro-acústica, também conhecida como implante coclear híbrido. O conceito do implante coclear híbrido foi desenvolvido em 1995 com o objetivo de desenvolver um eletrodo que pudesse ser implantado na base da cóclea e permitisse a preservação da audição nas frequências baixas (Roland et al., 2016), de modo que a audição natural nestas frequências pudesse fornecer pistas espectrais e refinamento auditivo. A figura 6 demonstra os possíveis limiares auditivos de pacientes candidatos á cirurgica com implante coclear híbrido ou estimulação eletro-acústica.

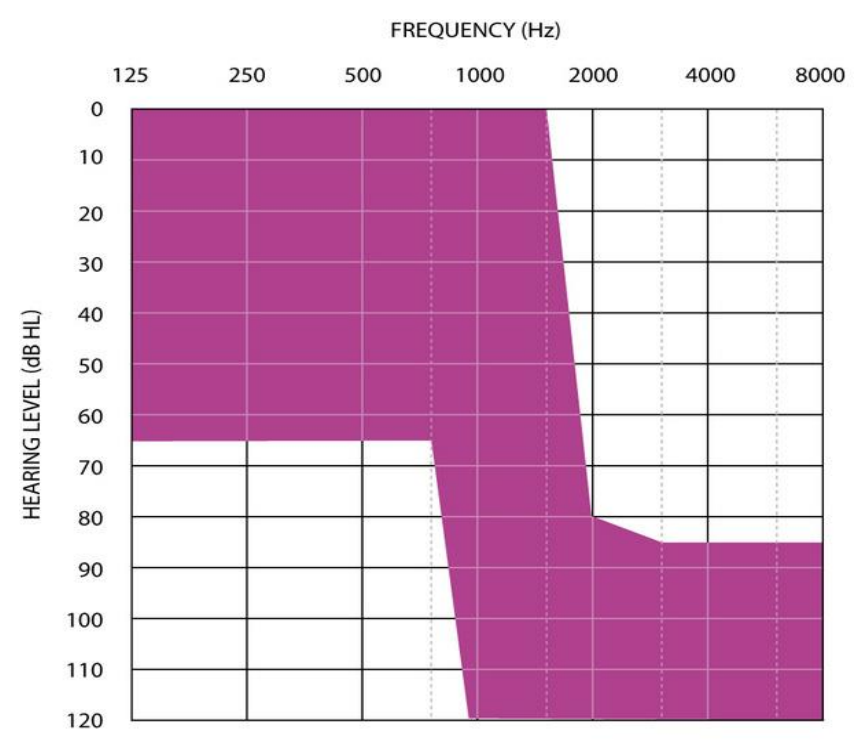

Figura 6 - Limites audiológicos para os candidatos ao implante coclear híbrido ou estimulação eletro-acústica. Fonte: https://www.cochlear.com/us/en/professionals/products/cochlearnucleus-hybrid-implant-system/candidacy) 
No entanto o conceito de mapeamento tonotópico cortical após privação sensorial também deve ser levado em consideração no momento da escolha pela melhor opção reabilitação auditiva para estes pacientes.

Diante do exposto, a hipótese deste trabalho é detectar a presença de zonas mortas cocleares em pacientes com perda auditiva em rampa descendente após o tratamento oncológico e verificar o benefício do uso de próteses auditivas identificando se 0 uso do recurso da limitação de frequências melhora a dificuldade de compreensão de fala. 


\section{REVISÃO DA \\ LITERATURA}




\section{REVISÃO DA LITERATURA}

\subsection{ZONAS MORTAS COCLEARES}

Moore (2001) definiu como zona morta coclear uma região na cóclea onde as células ciliadas internas e/ou neurônios adjacentes não estão funcionando. Deste modo, a informação gerada pela vibração da membrana basilar não é transmitida ao sistema nervoso central, não havendo transdução do sinal sonoro. Definiu o conceito de "off frequency listening" quando a vibração da membrana basilar é forte o suficiente para promover um espalhamento de vibração. Um tom puro que produza um pico de vibração na região morta poderá ser detectado em outro lugar na cóclea, onde a quantidade de vibração da membrana basilar for menor, mas cujas células ciliadas internas e/ou os neurônios adjacentes estejam saudáveis e funcionando com mais eficiência. Citou que a perda auditiva verdadeira numa zona morta é conceitualmente infinita e por isso não pode ser definida somente pelo audiograma, mas descreveu audiogramas indicativos de presença de zonas mortas cocleares: aqueles com limiares superiores a $90 \mathrm{dBNA}$ em frequências altas ou 75 a $80 \mathrm{~dB}$ em frequências baixas; aqueles com limiares entre 40 a 50 dBNA nas frequências baixas, mas com audição normal em frequências médias e altas; aqueles com limiares superiores a 50 dBNA nas frequências baixas e perda auditiva de grau leve em frequências altas; e aqueles com limiares que pioram bruscamente, mais do que $50 \mathrm{~dB}$ por oitava. $O$ autor propõe o teste TEN (Threshold Equalizing Noise) para diagnosticar as zonas mortas cocleares, descrevendo que este teste é baseado na detecção de senóides na presença de um ruído mascarador de banda larga, feito para produzir limiares mascarados em dBNPS. O ruído TEN é expresso em ERB (Equivalent Retangular Bandwidth) com a banda centrada em $1000 \mathrm{~Hz}$. Este foi formatado espectralmente e calibrado de maneira que o limiar mascarado, para quaisquer frequências entre 250 e $10000 \mathrm{~Hz}$, seja muito próximo ao nível de ruído testado com $95 \%$ de intervalo de confiança. Por exemplo, um nível de ruído testado em $70 \mathrm{~dB}$ deve produzir limiares mascarados pelo TEN em 70 dBNPS. Concluiu que este teste é um método simples e rápido para aplicação clínica. 
Moore et al. (2003) aplicaram o teste TEN em 33 adolescentes, com perda auditiva neurossensorial de grau severo a profundo, e compararam os resultados com um grupo controle com audição normal. Encontraram zonas mortas cocleares em 23 dos 33 pacientes testados $(69,7 \%)$, sendo que em três orelhas, a zona morta começava em $500 \mathrm{~Hz}$ e se estendia até as frequências altas, e o grau da perda auditiva era menos severa do que na maioria dos outros pacientes. Seis orelhas preencheram critério de zonas mortas cocleares para frequências baixas de 250 e $500 \mathrm{~Hz}$. Eles descrevem um alto índice de resultados inconclusivos, quando o limiar mascarado for $10 \mathrm{~dB}$ acima do limiar absoluto, mas não for $10 \mathrm{~dB}$ acima do ruído TEN, ou por ser o limiar absoluto muito alto e não haver possibilidade de mascará-lo. Não observaram diferenças na prevalência de zonas mortas cocleares em pacientes com perdas auditivas congênitas ou adquiridas.

Moore (2004) descreveu as vantagens do uso de teste TEN com relação às curvas psicofísicas, pois é mais rápido de ser administrado e os resultados não são afetados por detecção de outros tons combinados e sobrepostos. Sugere o uso em: pacientes que relatam na audiometria que o tom puro parece distorcido (pois o tom pode ter caído dentro da zona morta), em pacientes com pouco benefício com o uso de aparelhos auditivos já adaptados, na tentativa de oferecer informações que possam ajudar na programação dos aparelhos, em pacientes para determinar a candidatura ao implante coclear e em casos de medicina legal. Reafirmou também os critérios de interpretação do resultado do teste TEN: quando o limiar mascarado for $10 \mathrm{~dB}$ ou mais, acima do limiar absoluto e $10 \mathrm{~dB}$ ou mais acima do ruído TEN, o resultado é positivo para zonas mortas cocleares; quando o limiar mascarado for $10 \mathrm{~dB}$, ou mais, acima do limiar absoluto, mas não for $10 \mathrm{~dB}$ ou mais acima do ruído TEN, o resultado é negativo para zonas mortas cocleares; quando o limiar absoluto é tão alto que o limiar mascarado não pode ser obtido, o resultado é inconclusivo para zonas mortas cocleares. Afirmou que a presença de zonas mortas cocleares é bastante comum na prática clínica e encontrou $59 \%$ em $1000 \mathrm{~Hz}$ a $81 \%$ em $3000 \mathrm{~Hz}$ de zonas mortas cocleares presentes quando o limiar absoluto é de 75 
a $85 \mathrm{~dB}$, este valor sobe para $83 \%$ a $93 \%$ quando os limiares absolutos estão entre 80 e $85 \mathrm{~dB}$.

Moore et al. (2004) propuseram uma nova versão de aplicação do teste TEN, agora em dBNA e não mais em dBNPS, a fim de tornar o teste mais rápido e fácil de ser aplicado e interpretado. Afirmaram que o ruído TEN foi calibrado de maneira que o nível do ruído e o nível do tom teste já correspondem aos valores indicados no audiômetro. Sugeriram a determinação dos limiares em passos de $2 \mathrm{~dB}$, por considerarem o teste mais sensível.

Jacob et al. (2006) aplicaram o teste TEN em 101 orelhas de 57 pacientes que foram divididos em três grupos: grupo1: pacientes com audição normal, grupo 2: pacientes com perda auditiva neurossensorial plana de grau moderado e grupo 3: pacientes com perda auditiva neurossensorial descendente com graus diversos, de leve a profundo. Em seus resultados, puderam confirmar a efetividade do mascaramento durante 0 teste $e$ encontraram presença de zonas mortas cocleares em $92 \%$ das orelhas com perdas auditivas neurossensoriais descendentes e ausência de zonas mortas cocleares em perdas auditivas planas. Sugerindo que o TEN é um bom teste para identificar a presença de zonas mortas cocleares.

Vinay e Moore (2007) realizaram o teste TEN em 308 pacientes (556 orelhas) e observaram que 177 pacientes $(57,4 \%)$ tinham zonas mortas em uma ou ambas as orelhas, em pelo menos uma frequência. 256 orelhas (46\%) apresentaram zonas mortas em uma frequência ou mais, 233 orelhas $(41,9 \% \%)$ apresentaram zonas mortas somente em frequências altas, 13 orelhas $(2,3 \%)$ apresentaram zonas mortas somente em frequências baixas e somente 10 orelhas $(1,8 \%)$ apresentaram zonas mortas em frequências altas e baixas, com preservação das frequências médias. Descreveram uma sensibilidade de $95 \%$ no teste quando o limiar absoluto audiométrico é de 70 dBNA, com especificidade de 92\%. Com relação à configuração das perdas auditivas, um audiograma em rampa pode ser um fator preditivo da presença de zonas mortas cocleares, a prevalência da positividade nestes casos foi de 16\%. A prevalência não variou de acordo com a idade nem sexo. 
Cairns et al. (2007) verificaram a repetibilidade do teste TEN em diferentes populações. Os pacientes não foram pareados por idade, grau de perda auditiva ou etiologia da perda auditiva. O critério de inclusão foi exclusivamente a presença de zona morta coclear. Todos os pacientes tinham curva timpanométrica normal e foram divididos em dois grupos. O grupo dos adolescentes tinha idade entre 12 a 17 anos, com limiar por via aérea de, no mínimo, 80 dBNA na melhor orelha, e com gap aéreo-ósseo inferior a 15 dB. Neste grupo, 23 orelhas de 15 pacientes foram avaliadas. O grupo dos adultos tinha idade entre 54 e 86 anos, com média tonal entre 41 e 95 dB e com gap aéreo-ósseo menor ou igual a $10 \mathrm{~dB}$. Neste grupo, foram avaliadas 40 orelhas de 20 pacientes. Aplicaram o teste em duas visitas, com intervalo de cinco dias entre as avaliações. No grupo dos adolescentes, a diferença entre os limiares mascarados entre a primeira e a segunda aplicação variou de $-0.81 \mathrm{a}+0.91 \mathrm{~dB}$, dependendo da frequência. No grupo dos adultos, esta variação foi de 0.10 a 1. $40 \mathrm{~dB}$, com 95\% da variação dos limiares de $\pm 6 \mathrm{~dB}$ nas frequências entre 500 e $3000 \mathrm{~Hz}$. Das 23 orelhas avaliadas no grupo dos adolescentes, 11 (48\%) preencheram os critérios para zonas mortas cocleares no primeiro teste, oito $(35 \%)$ mudaram de categoria no reteste, sendo que seis $(26 \%)$ mudaram para indeterminado, dois (9\%) para ausência de zona morta. Das 40 orelhas testadas no grupo dos adultos, 21 (52,5\%) preencheram o critério para presença de zona mortas coclear na primeira avaliação. Oito (20\%) mudaram de categoria no reteste, destes seis (15\%) preencheram o critério somente na primeira avaliação e dois (5\%) somente na segunda avaliação. Concluíram que o teste apresenta boa repetibilidade, mas que a técnica de passos de 2 em 2 $\mathrm{dB}$ é mais precisa.

Aazah and Moore (2007) avaliaram 108 pacientes idosos com perda auditiva neurossensorial descendente, com limiares absolutos entre 65 a 90 dBNA em $4000 \mathrm{~Hz}$. Aplicaram o teste TEN em dBNA e o nível de mascaramento do ruído TEN nunca foi superior a 95 dBNA. A média de idade foi de 79,6 anos no grupo de pacientes com zonas mortas cocleares e 76,6 anos no grupo sem zonas mortas cocleares. A média do limiar absoluto em $4000 \mathrm{~Hz}$ foi de $71.1 \mathrm{~dB}$ no grupo com zonas mortas e de $66,5 \mathrm{~dB}$ no grupo sem 
zonas mortas. Das 98 orelhas avaliadas, 37\% apresentaram resultado positivo para presença de zonas mortas cocleares. Não encontraram correlação da presença de zonas mortas cocleares com a configuração inclinada do audiograma.

Moore and Vinay (2009) reafirmaram que a extensão de uma zona mortas é definida em termos de sua frequência limite fe (frequency edge), que corresponde à frequência característica das células ciliadas internas e/ou neurônios íntegros, imediatamente adjacentes à zona mortas. Em 2004, ele já havia definido sua extensão em termos anatômicos, tomando-se a base da cóclea como referência, uma zona morta basal estaria entre 0 a $12 \mathrm{~mm}$ e uma zona morta apical estaria entre 15 a $32 \mathrm{~mm}$.

Markesis et al. (2009) estudaram o efeito do nível de apresentação do ruído TEN no teste para diagnosticar zonas mortas cocleares em 23 adultos. 19 tinham perda auditiva neurossensorial de grau leve a moderado em frequências altas, três tinham perdas de grau leve a moderado em frequências baixas e um tinha uma perda auditiva plana de grau profundo. Pesquisaram os limiares mascarados nas frequências de 750 a $4000 \mathrm{~Hz}$, com ruído TEN nas intensidades de 60, 70, 80 e 90 dBNA/ERB, em duas sessões, em dias seguidos. Relataram que as mudanças nunca foram superiores a $-1.2 \mathrm{~dB}$ nos limiares absolutos e +0.5 dB nos limiares mascarados, mostrando uma boa repetibilidade e concluíram que a presença de zonas mortas cocleares raramente está presente quando o limiar absoluto é inferior a 70dBNA.

Hornsby et al. (2009) avaliaram 59 adultos com perdas auditivas simétricas, curvas timpanométricas do tipo A e sem alterações cognitivas medidas por meio do Short Portable Mental Status Questionnaire. Realizaram o teste TEN com passos de $5 \mathrm{~dB}$ pois acreditam ser clinicamente mais factível, além de acreditarem que a especificidade é maior, pois o número de falsos positivos será menor do que com passos de $2 \mathrm{~dB}$. Encontraram correlação entre o grau da perda auditiva e a positividade no teste TEN, quanto menor o grau de perda auditiva, menor a presença de zonas mortas cocleares. A média das frequências com resultado negativo para o teste foi de $48.6 \mathrm{~dB}, 70 \%$ dos 
casos negativos estavam correlacionados com limiares auditivos absolutos abaixo de 60 dBNA, mas encontraram 39\% de testes positivos nestes mesmos limiares. Relataram casos isolados de presença de positividade mesmo para limiares entre 20 e $30 \mathrm{~dB}$. Com relação à frequência, descreveram $5 \%$ de ocorrências de testes positivos nas frequências entre 250 a $3000 \mathrm{~Hz}, 9 \%$ na frequência de $4000 \mathrm{~Hz}$ e 30\% em 6000 e 8000 Hz. Os resultados inconclusivos aumentaram de acordo com o aumento da frequência, observaram 60 a $70 \%$ em 6000 e $8000 \mathrm{~Hz}$, em função do elevado limiar absoluto. Com relação à configuração, pacientes com audiograma em rampa acentuada tiveram três vezes maior ocorrência de testes TEN positivos, quando comparados a audiogramas planos ou com perdas auditivas de grau moderado.

Ahadi et al. (2015) para estudar a prevalência de zonas mortas cocleares em crianças, avaliaram oito meninas e 22 meninos, com idade de 5 a 14 anos, com limiares auditivos de 45 a 85 dBNA nas frequências de 500 a $4000 \mathrm{~Hz} .23$ das 30 crianças (76\%) apresentaram resultado no teste TEN em pelo menos uma frequência, sendo que 12 crianças apresentaram resultado positivo em ambas as orelhas. Ou seja, 35 das 60 orelhas $(58,3 \%)$ apresentaram positividade no teste TEN. A média dos valores dos limiares absolutos foi estatisticamente significantemente maior nas frequências de 500 , 750 e $1000 \mathrm{~Hz}$ nas crianças que apresentaram resultados positivos no teste TEN. A média dos limiares de PTA de 500 a $2000 \mathrm{~Hz}$ foi de 59,6 $\pm 5.4 \mathrm{~dB}$ nas crianças que não apresentaram zonas mortas cocleares e de $73.1 \pm 11.6 \mathrm{~dB}$ nas crianças com zonas mortas cocleares, com $\mathrm{p}<0.02$.

Lee et al. (2015) a relataram aplicação do teste TEN em 191 orelhas de 109 pacientes com diferentes etiologias de perdas auditivas sensorioneurais e encontraram $15,7 \%$ de pacientes com resultados positivos para zonas mortas cocleares em perdas auditivas sensorioneurais, em $14,3 \%$ do pacientes com surdez súbita e relataram a ocorrência em um caso de trauma acústico e em um caso de Herpes Zoster. Resultados negativos no teste TEN em pacientes com otite média crônica e doença de Meniére. A maior prevalência de zonas mortas cocleares se deu nas perdas de grau moderadamente severo (50\%) e na frequência de $4000 \mathrm{~Hz}$ e em uma única frequência por orelha. 
Choi et al. (2016) descreveram a aplicação do teste TEN em pacientes com surdez súbita. Foram avaliados pacientes de 2010 a 2015, cujos limiares auditivos apresentaram piora de $30 \mathrm{~dB}$ em três frequências consecutivas, num intervalo menor de três dias seguidos e excluíram casos de infecção viral ativa, neurinoma e anomalias congênitas. Foram avaliados 101 pacientes (112 orelhas), destas 11 com perdas bilaterais. Dividiram os pacientes em dois grupos, um com zonas mortas cocleares e outro sem zonas mortas cocleares. Encontraram $31 \%$ de prevalência de zonas mortas positivas, em pelo menos uma frequência. Nos audiogramas de seguimento, o grupo com zonas mortas cocleares apresentou limiares auditivos significantemente pior, apesar de serem semelhantes na avaliação inicial. O IPRF também foi, estatisticamente, pior no grupo com zonas mortas cocleares, independentemente do tempo da avaliação audiológica. Dentre os pacientes com zonas mortas também não se observou recuperação completa ou parcial da audição.

\subsection{REABILITAÇÃO AUDITIVA NAS PERDAS AUDITIVAS EM RAMPA}

\subsubsection{USO DA LIMITAÇÃO DE FREQUÊNCIAS NAS PRÓTESES AUDITIVAS}

Ching et al. (1998) avaliaram a quantidade de informação de fala que pode ser extraída por pacientes com diferentes perdas auditivas em diferentes níveis de sensação. Referiram que pacientes com perdas auditivas de grau leve ou moderado podem ter sua performance predizível com base na audibilidade dos sons de fala, uma vez que possuem a capacidade de identificação destes sons preservada. Pacientes com perdas auditivas de maior grau precisam de maiores níveis de pressão sonora para identificar os sons de fala e isto pode causar distorção nestes sons. Estes pacientes também têm o nível de sensação afetado, o que prejudica sua capacidade de extrair informação dos sons audíveis e o reconhecimento de fala piora à medida que a audibilidade aumenta nas frequências em que a perda auditiva é de grau severo. A contribuição da audibilidade para a inteligibilidade de fala pode ser 
negativa e, portanto, fornecer amplificação às frequências altas pode ser contraproducente.

Baer et al. (2002) descreveram o efeito do filtro passa-baixo na inteligibilidade de fala em dez pacientes com perda auditiva neurossensorial descendente, com e sem presença de zonas mortas cocleares em frequências altas. O teste de reconhecimento de monossílabos foi feito no silêncio, a 65 dBNA, com amplificação e com o filtro passa-baixo acionado, de maneira monoaural. Observaram que os escores melhoram com 0 aumento da frequência de corte do filtro, em pacientes com e sem zonas mortas. Referiram que, nos pacientes com zonas mortas cocleares, o desempenho melhora com o filtro até 1,7 vezes o início da frequência limite do início da zona morta, e tende a se estabilizar após.

Simpson et al. (2005) por acreditarem que alguns aparelhos auditivos podem não fornecer audibilidade suficiente em frequências altas, prejudicando o reconhecimento de fonemas fricativos, descreveram o desempenho em testes de percepção de fala em dez pacientes adultos, com perda auditiva neurossensorial moderada a severa, em frequências altas, com diferentes frequências de cortes de filtros. O objetivo dos autores era fornecer a maior quantidade de amplificação possível sem causar desconforto. Os pacientes deveriam identificar monossílabos em lista fechada apresentados a 60 dBNA. Todos os pacientes tiveram limiares com prótese auditiva dentro ou abaixo da banana da fala e observaram melhor reconhecimento dos fonemas fricativos, à medida que se aumentava a largura de banda, sugerindo que esse aumento assegura a audibilidade para sons de fala e, deste modo, melhora sua compreensão. Do mesmo modo, a piora da performance pode ser explicada pela não amplificação adequada das frequências altas.

Hornsby et al. (2006) estudaram 30 pacientes: dez com audição normal, dez com perdas auditivas sensorioneurais planas e dez com audiogramas em rampa acentuada. Aplicaram testes de reconhecimento de sentenças no ruído com diferentes filtros e comprovaram que, pacientes com perda auditiva em rampa acentuada são capazes de usar informação da amplificação sonora em 
frequências altas (acima de $3000 \mathrm{~Hz}$ ) para melhorar sua compreensão de fala, mas a quantidade da melhora é pequena. Sugeriram que esta dificuldade pode ser pela quantidade de amplificação necessária para tornar os sons audíveis. Mostraram que a dificuldade também está presente em pacientes com perda auditiva plana, sugerindo que a configuração da perda auditiva não deve limitar o uso da amplificação da informação sonora proveniente das frequências altas. Concluiram que perdas auditivas superiores a 60-80 dBNA tem menor beneficio com a amplificação da informação de fala de maneira uniforme e não dependente das frequências.

Gifford et al. (2007) estudaram seis pacientes usuários de aparelhos auditivos há mais de cinco anos e tiveram seus dispositivos ajustados com limitação de frequências. Aplicaram os sons do Ling para ajustar a programação dos aparelhos. Os testes de percepção de fala incluíram reconhecimento de monossílabos, palavras e frases. As tarefas foram feitas no silêncio e no ruído com relação sinal ruído $+10 \mathrm{~dB}$, de maneira mono e binaural a 70 dBNPS, na programação com e sem limitação de frequências. Nos testes com amplificação convencional não houve diferença estatisticamente significante, comparando as tarefas mono versus binaurais. Na programação com limitação de frequências, notaram diferença estatisticamente significante na tarefa de reconhecimento de sentenças, tanto no silêncio como no ruído. 0 reconhecimento de monossílabos foi de $42 \%$ e $48 \%$, respectivamente. 0 reconhecimento de sentenças no silêncio foi de $80 \%$ e $90 \%$, respectivamente com $\mathrm{p}=0.034$ e no ruído $46 \%$ e $56 \%$ respectivamente com $\mathrm{p}=0.004$. No entanto a maioria dos pacientes (66\%) referiu algum problema associado à limitação de frequências, preferindo a amplificação convencional.

Einarsson et al. (2010) descreveram as dificuldades impostas pelas perdas auditivas adquiridas após quimioterapia com derivados da platina. $\mathrm{A}$ ototoxicidade leva a múltiplas deficiências na audição, alguns sons simplesmente não são ouvidos, o loudness dos sons da fala por sua vez podem parecer altos o suficiente, pois eles têm acesso aos sons de frequências baixas, mas a fala poderá não ser compreendida pois faltará a informação proveniente das frequências altas. Com o avançar da idade este 
loudness também será perdido. A perda das células ciliadas externas pode causar uma alteração nas curvas psicoacústicas, levando à inabilidade coclear de diferenciar fala no ruído, quando estes sons tiverem uma frequência muito próxima. Estudaram 15 adolescentes sendo seis com perda auditiva após o tratamento, observaram uma média de $91,7 \%$ na melhor orelha e de $89,3 \%$ na pior orelha, nos testes de reconhecimento de fala no silêncio e de $32,8 \%$ e $24,7 \%$, respectivamente no ruído. Os sete pacientes com audição normal apresentaram $100 \%$ de acertos no silêncio e 86,8\% e 83,3\% para a melhor e a pior orelha no ruído. Quatro dos dez pacientes tiveram próteses auditivas adaptadas com adaptação aberta em ambas as orelhas. Nestes pacientes, o maior benefício se deu no reconhecimento de fala no ruído, com média de $46 \%$ de melhora. Os autores reforçaram a necessidade de realização de testes de percepção de fala no ruído, ou a aplicação de um questionário HMS (Hearing Measurement Scale) para as crianças muito pequenas que não são capazes de realizar os testes de fala, para avaliar o handicap, e afirmaram a importância da adaptação precoce de próteses auditivas adaptadas às particularidades de cada paciente.

Cox et al. (2011) estudaram 170 pacientes, destes, 53 (31\%) apresentaram presença de zonas mortas cocleares, a maioria em apenas uma única frequência. Depois separaram os pacientes em dois grupos, um com presença e outro com ausência de zonas mortas e aplicaram uma lista de 12 sentenças que foram gravadas com ênfase em frequências altas, começando em $1000 \mathrm{~Hz}$ e com ganho adicional de 32 dB em $4000 \mathrm{~Hz}$. Encontraram diferença estatisticamente significante entre os grupos e concluíram que o ganho adicional e as pistas em frequências altas provou ser favorável no reconhecimento de fala em ambos os grupos. O grupo sem presença de zonas mortas cocleares mostrou maior benefício, sugerindo que pacientes com zona morta coclear têm menor habilidade em explorar pistas acústicas da fala em frequências altas.

Einarsson et al. (2011) avaliaram 15 adolescentes que foram tratadas durante sua infância entre os anos de 1985 e 2000. Foram divididas em dois grupos, seis crianças no grupo com perda auditiva e oito com audição normal. 
Realizaram avaliação audiológica composta por audiometria tonal, reconhecimento de monossílabos no silêncio e no ruído, mono e binauralmente e aplicaram o questionário HMS (Hearing Measument Scale) antes e após a adaptação de próteses auditivas open-fit. Todos os participantes tinham audição normal ao início do tratamento oncológico. A média dos valores do reconhecimento do monossílabos no silêncio, no grupo com perda auditiva na condição monoaural foi de $91,7 \%$ na melhor orelha e $89.3 \%$ na pior, e de $100 \%$ no grupo com audção normal. No ruído, a média foi de 32,8\% na melhor orelha e $24,7 \%$ na pior orelha no grupo com perda auditiva, e de, 86,8\% na melhor orelha e $83,3 \%$ na pior orelha, no grupo com audição normal. Os autores descrevem a correlação entre a média dos limiares auditivos com os escores obtidos no reconhecimento de fala no silêncio. Após a adaptação de próteses auditivas open-fit, descrevem uma melhora no reconhecimento de fala no ruído, com relação sinal ruído variando entre -2 e $-11 \mathrm{~dB}$, com melhora estatísticamente significante de $46 \%$ na relação sinal ruído de $-5 \mathrm{~dB}$. A pontuação do questionário HMS também apresentou melhora com média de $61,7 \%$ menos dificuldades após o uso das próteses auditivas.

Hornsby et al. (2011) determinaram que o grau da perda auditiva é o preditor mais forte da performance e dos benefícios, nos testes de percepção de fala em pacientes com perda auditiva em frequências altas com amplificação estendida. Estudaram 74 adultos, 12 com audição normal e 62 com perda auditiva neurossensorial em frequências altas. Realizaram testes de identificação de sentenças no ruído com filtros passa-alto e passa-baixo, com relação sinal ruído variando de $-2 \mathrm{~dB}$ a $+20 \mathrm{dBNA}$. Encontraram resultados que indicam que não há consequências negativas em oferecer amplificação em maior quantidade de bandas e frequências possível, independentemente do grau e da configuração das perdas auditivas. A compreensão de fala com amplificação estendida foi melhor do que em qualquer condição de fala filtrada.

Cox et al. (2012) estudaram dois grupos de 18 pacientes pareados, um com zonas mortas cocleares e outro sem zonas mortas. Os pacientes usaram aparelhos auditivos com dois programas, um com amplificação convencional e outro com ganho suavizado com limitação de frequências a partir de $1000 \mathrm{~Hz}$. 
Permaneceram 15 dias para permitir aclimatização antes de iniciarem os testes de percepção de fala no silêncio e no ruído, que foram feitos com gravação à 65 dBNA. Os pacientes também eram instruídos a registrar e pontuar as tarefas do dia-a-dia em que apareciam dificuldades para reconhecer palavras em cada um dos programas, duas vezes por dia. As análises estatísticas mostraram que, no reconhecimento de fala no silêncio, o programa com amplificação convencional permitiu uma melhor performance em ambos os grupos. Para o reconhecimento de sentenças no ruído, este programa também mostrou ser melhor, mas somente nos pacientes sem zonas mortas cocleares. $\mathrm{Na}$ pontuação das tarefas diárias, o programa com amplificação convencional mostrou maior benefício, mas somente para o grupo de pacientes com zonas mortas cocleares. Os autores concluiram que não há razões para limitar o ganho prescrito somente baseado na presença de zonas mortas cocleares, uma vez que estes pacientes se beneficiaram de pistas acústicas fornecidas por esta amplificação.

Zhang et al. (2014) avaliaram a prevalência da presença de zonas mortas cocleares em 22 pacientes bimodais, que fazem uso de aparelho de amplificação sonora individual na orelha contralateral ao implante coclear tradicional. Realizaram testes de percepção de fala no silêncio e no ruído com relação sinal ruído de $+10 \mathrm{~dB}$. Observaram que o reconhecimento de monossílabos no silêncio, em pacientes com zonas mortas cocleares, foi significativamente melhor com a prótese auditiva isolada e associada ao uso do implante, quando a amplificação foi limitada à frequência limite da zona morta. No reconhecimento de sentenças com relação sinal ruído de $+10 \mathrm{~dB}$ em pacientes com zonas mortas cocleares houve diferença estatisticamente significante $(p<0.001)$ quando a prótese auditiva foi programada com amplificação até a frequência limite da zona morta identificada pelo teste de TEN junto com o implante coclear. Observaram escores na identificação de monossílabos de $32 \%$ somente com a a prótese auditiva, 78\% com a prótese auditiva junto com o implante coclear e $89 \%$ com ambos os dispositivos mas com amplificação restrita á frequência de início da zona morta. Os autores enfatizaram a importância da realização do teste TEN para identificação de 
zonas mortas cocleares em pacientes bimodais, para melhor ajuste do aparelho auditivo, e relatando a necessidade de se reduzir a amplificação, acima da frequência limite da zona mortas, para evitar a dispersão da informação acústica e, deste modo, evitar distorção na amplificação, promovendo melhora no desempenho com ambos os dispositivos acionados.

Alexander et al. (2014) compararam o efeito da compressão e da transposição de frequências na percepção de fonemas fricativos, em 24 pacientes com perdas auditivas de grau moderado a severo a partir de $3000 \mathrm{~Hz}$ e em 24 normo-ouvintes de 18 a 50 anos. Observaram um desempenho significantemente pior com a transposição de frequências acionada em ambos os grupos. Selecionaram 12 dos 24 pacientes com perda auditiva e avaliaram somente a condição de compressão de frequências, com frequência inicial da compressão em 4,6 kHz e observaram desempenho significantemente melhor com a compressão de frequências acionada $(p<0,001)$, sugerindo o potencial benefício do uso de compressão de frequências, em pacientes com perda auditiva em frequências altas.

Brennan et al. (2014) compararam o processamento do som com banda larga estendida e com banda restrita, em crianças e adultos com perdas auditivas. Avaliaram 16 crianças, com média de idade de 12 anos e 16 adultos com média de 45 anos, com perdas auditivas de grau leve a severo. Aplicaram uma lista de 15 sentenças no silêncio a 60 dBNPS que incluíam, pelo menos, três fonemas fricativos por sentença e também oito trechos musicais. As próteses auditivas foram programadas de acordo com o software da empresa com a compressão de frequências predeterminada pelo próprio software. Os resultados mostraram que a maioria dos pacientes preferiu maior acesso às informações vindas das frequências altas, ou seja, com largura estendida de banda. Também relataram maior clareza nos sons de fala do que na música.

Marchesin e lorio (2015) avaliaram a detecção de consoantes, o índice de reconhecimento de fala e o índice porcentual de identificação de fonemas fricativos, em 32 pacientes adultos com perda auditiva neurossensorial de grau moderado a severo em frequências altas divididos em dois grupos. Um grupo 
teve o algoritmo de limitação de frequências acionado e outro não. Pacientes eram novos usuários e foram adaptados com próteses auditivas retro auriculares convencionais e com molde invisível duplo de acrílico e ventilação de 2,5 mm. Observaram que o grupo que teve a limitação de frequências acionada apresentou escores superiores. A pontuação no questionário APHAB (Abbreviated Profile of Hearing Aid Benefit) não refletiu a melhora observada clinicamente.

Pepler et al. (2016) avaliaram 36 adultos com perdas auditivas sensorioneurais de grau moderado, sendo 18 orelhas com presença de zonas mortas cocleares e 18 orelhas sem zonas mortas cocleares. A média do reconhecimento das consoantes no silêncio foi de $86 \%$ nos pacientes sem zona morta e $84 \%$ nos pacientes com zona morta. Na presença de ruído, a média foi de $67 \%$ nos pacientes sem zona morta e $59 \%$ nos pacientes com zona morta, com a programação sem filtros, mostrando uma diferença estatisticamente significante na condição da presença de ruído entre os dois grupos $(p=0,001)$. A média dos escores na presença do ruído tipo babble foi $10 \%$ pior do que no silêncio. A média do benefício da amplificação nas frequências acima de $3000 \mathrm{~Hz}$ foi similar entre os grupos no silêncio e na presença do ruído (5\%). A média dos benefícios foi de $13 \%$ nos pacientes sem zona morta e 6\% nos pacientes com zona morta coclear $(p=0.003)$. Os autores concluíram que não encontraram evidências que suportem a limitação da amplificação de frequências altas.

Salorio-Corbetto et al. (2017) desenharam um estudo para determinar se a limitação de frequências piora a qualidade do som de fala, quando o valor da frequência de início da compressão é baixo. Avaliaram oito orelhas de cinco pacientes com perda auditiva descendente e com zonas mortas cocleares, com valores de frequências de início de limitação entre 800 a $1400 \mathrm{~Hz}$. Usaram pares de som, nos quais um som era a referência e o outro era comprimido. Os pacientes deveriam indicar qual era o melhor som. Observaram piora da qualidade do som de fala com o aumento da compressão, no entanto a piora foi pequena, indicando que a compressão produz degradação moderada da qualidade do som. Análises revelaram que a qualidade do som de fala piora 
quando os valores da frequência inicial da limitação estão pareados com maiores valores de razão de compressão. De maneira geral a limitação de frequências aumentou a quantidade de frequências que são audíveis quando comparadas ao som referência. A degradação do som de fala pode limitar a aceitação do uso de limitação de frequências.

\subsubsection{IMPLANTE COCLEAR HÍBRIDO OU ESTIMULAÇÃO ELETROACÚSTICA}

Woodson et al. (2010) descreveram o critério para indicação á cirúrgia do implante coclear híbrido como sendo: pacientes acima dos 15 anos de idade com limiares em $500 \mathrm{~Hz}$ melhores do que $60 \mathrm{dBNA}$, limiares a partir de 2000 $\mathrm{Hz}$ devem ser maiores ou iguais a 80 dBNA e performance moderada em testes de percepção de fala em contexto aberto, com um reconhecimento de monossílabos entre $10 \%$ e $60 \%$ na orelha a ser implantada e não maior do que $80 \%$ na orelha contralateral. Os autores reforçam a necessidade da orientação sobre o risco da perda da audição residual com o procedimento cirúrgico.

Skarzynski e Lorens (2010) proposuram um novo tratamento para a surdez parcial em pacientes com perda auditiva em rampa com limiares auditivos normais em frequências baixas e com perda quase total em frequências altas. Definiram que existem três diferentes categorias de pacientes: 1 - Complemento elétrico: pacientes com audição normal ou com limiares levemente elevados nas frequências baixas e perda quase total da audição nas frequências altas, sem amplificação nas frequências baixas com estimulação elétrica somente pelo implante coclear. 2- Estimulação elétroacústica: pacientes com perda auditiva de grau leve a severo nas frequências baixas e profundo nas frequências altas. Neste grupo de pacientes, a audição residual é amplificada acusticamente com próteses auditivas em combinação com estimulação elétrica com implante coclear na mesma orelha. 3Estimulação elétrica: somente usada nas orelhas implantadas em casos de perda nas frequências baixas após a cirurgia com preservação não funcional da audição. Analisaram limiares audiométricos e precepção de fala em 95 
pacientes, sendo 63 adultos e 32 crianças com surdez parcial que receberam implantes cocleares com técnicas cirúrgicas que visassem a preservação da audição. Avaliaram a percepção de fala com material apresentado a 60dBNA em campo livre, no silêncio e no ruído, com relação SNR +10dB. Observaram melhora significativa nos escores ao longo do tempo em todos os três grupos de pacientes com média de $34 \%$ para $73 \%$ no silêncio e de $7 \%$ para $54 \%$ no ruído. No grupo com estimulação elétro-acústica a melhora foi de $30 \%$ para $70 \%$ com $p=0,000$ no silêncio e de $3 \%$ para $50 \%$ no ruído. No grupo com estimulação elétrica a melhora foi de $42 \%$ para $84 \%$ no silêncio com $p=0,000$ e de $15 \%$ para $68 \%$ no ruído.

Kopelovich et al. (2014) descreveram os fatores de risco para perda do resíduo auditivo após cirurgia para colocação do implante híbrido. Avaliaram retrospectivamente os dados audiométricos de 85 pacientes que realizaram cirurgia de 1999 a 2008. As avaliações audiológicas foram feitas no préoperatório, na ativação (um mês após a cirurgia) três, seis e 12 meses após. Encontraram correlação estatisticamente significante entre idade e sexo masculino. Também houve correlação entre problemas cardiovasculares e maior susceptibilidade a piora auditiva após o implante, mas sem significância estatística. A etiologia parece ter correlação com a saúde geral. Pacientes com perdas auditivas induzidas por ruído tiveram maior piora auditiva após o implante e também tiveram pior performance nos testes de percepção de fala. Os autores também descreveram a ocorrência de perda auditiva após a estimulação elétrica, que pode estar correlacionada com altos níveis de estimulação, exacerbando um dano já existente nas estruturas neurais aferentes. O resíduo auditivo na orelha implantada não teve correlação com as medidas de compreensão de fala, sobretudo na condição binaural, sugerindo que a audição residual da orelha contralateral também ajuda.

Erixon et al. (2015) mediram a satisfação de 19 pacientes que fizeram implante híbrido e correlacionaram com os resultados auditivos após dois anos de acompanhamento. Descreveram que na avaliação para candidatura ao implante híbrido existem duas categorias de pacientes: aqueles que têm limiares auditivos normais nas frequências baixas e que não necessitarão de 
amplificação e aqueles que têm perda auditiva nestas frequências e que se beneficiarão de amplificação acústica nesta região. Descreveram os critérios audiológicos para a candidatura ao implante coclear híbrido: limiares auditivos menores ou iguais a 65 dBNA nas frequências até $500 \mathrm{~Hz}$ e limiares auditivos superiores a 80 dBNA, a partir de $2000 \mathrm{~Hz}$ com limiares aproximadamente simétricos na orelha contralateral e com discriminação de monossílabos abaixo de $60 \%$. Avaliaram os pacientes por meio de audiometria tonal, testes de percepção de fala, com monossílabos apresentados de 65 a 85 dBNA, com e sem o aparelho auditivo e com sentenças apresentadas no ruído. Os resultados, após 12 meses da cirurgia, foram 52\% de discriminação de monossílabos. A satisfação foi medida por meio de um questionário e 18 dos 19 pacientes estavam muito satisfeitos com o dispositivo e com seu resultado, o outro paciente respondeu que estava satisfeito. 15 pacientes relataram que a música também estava boa ou muito boa. Na conclusão, os autores afirmaram que a estimulação elétrica oferece uma grande contribuição à compreensão de fala em pacientes com surdez parcial. Todos os pacientes que fizeram a cirurgia para o implante coclear híbrido estavam satisfeitos e a preservação da audição acontece de fato. Isto constitui um benefício adicional na compreensão de fala e que esta possibilidade de reabilitação deve ser oferecida a pacientes com surdez parcial.

Guimarães et al. (2015) estudaram retrospectivamente os fatores que contribuem para uma maior taxa de preservação da audição em cirurgias de implante coclear híbrido, num estudo mutlicêntrico. Aplicaram a mesma técnica minimamente invasiva e utilizaram o mesmo eletrodo (MED_EL FLEX TM EAS) de 24 milímetros, em todos os 19 pacientes avaliados, 10 homens e 9 mulheres. Os critérios de inclusão selecionaram pacientes com limiares auditivos melhores do que $65 \mathrm{~dB}$ nas frequências de 125, 250 e $500 \mathrm{~Hz}$ e limiares auditivos piores do que $80 \mathrm{~dB}$ a partir de $1000 \mathrm{~Hz}$, com porcentagem de reconhecimento de fala de palavras monossilábicas inferior a $40 \%$ na melhor condição de amplificação possível e com estabilidade da perda auditiva há no mínimo dois anos. Os critérios para preservação residual da audição foram: preservação total de 0 a $10 \mathrm{~dB}$ de perda audiitva na avaliação pós cirurgia; 
preservação parcial da audição com piora de $<10 \mathrm{~dB}$ enquanto mantiver limiares audiométricos elétricos de até $80 \mathrm{~dB}$ nas frequências de 250 a $1000 \mathrm{~Hz}$ e sem preservação auditiva quando não há o benefício do uso da estimulação eletro-acústica pois os limiares auditivos elétricos estão ausentes. Em 5 pacientes houve preservação total da audição residual e em 12 a preservação foi parcial. Concluiram apresentando uma taxa global de preservação da audição de $89,4 \%$ sendo $27 \%$ de preservação total da audição e $63 \%$ de preservação parcial.

Ryu et al. (2015) realizaram monitorização auditiva em três crianças com neuroblastoma durante o tratamento oncológico que incluia avaliação audiológica com audiometria de reforço visual e ABR. Todos apresentaram piora auditiva ao longo do tratamento e ao final do tratamento oncológico todos receberam implantes cocleares com idades de 67,9 e 75 meses. $O$ critério para indicação da cirurgia foi 0 não benefício com as próteses auditivas. Observaram melhora nos testes de identificação de monossílabos de $22.6 \%$ para $78,6 \%$ de dissílabos de $45,3 \%$ para $86,6 \%$ e de sentenças de $24,6 \%$ para $90,6 \%$. Os autores concluiram que o tratamento oncológico pode causar perda auditiva em rampa e que o implante coclear é uma alternativa viável de tratamento utilizando-se de ténica adequada que permita a preservação auditiva. Reforçaram a importância da adequada intervenção e reabilitação audiológica em crianças em idade de desenvolvimento de fala e linguagem para permitir desenvolvimento psicológico e acadêmico adequados

Ciesla et al. (2016) avaliaram o estress mental e a qualidade de vida em pacientes com perda auditiva parcial, definida como perda audiitva em rampa. Realizaram avaliação audiológica e entrevista psicológica na qual aplicaram questionários em 31 pacientes adultos abaixo dos 50 anos e em 31 controles. No grupo de pacientes 14 tinham uma perda auditva pré lingual e 17 perda auditiva pós lingual, sendo 16 mulheres e 15 homens. 19 pacientes faziam uso regular de próteses auditivas e 12 pacientes não eram usuários pois não tinham benefício com as próteses. A avaliação audiológica consistiu na determinação dos limiares auditivos e na identificação de palavras monossílabicas. Os questionários aplicados foram BDI Beck Depression 
Inventory, o STAI State-Trait Aniety Inventory e o WHOQOL- BREF. Observaram um escore maior em todos os questionários no grupo de pacientes com perda auditiva, inicando mais sintomas psicopatológicos nesta população, sem diferença entre os pacienes pré e pós linguais. Os autores afirmaram que pacientes com surdez parcial são uma população muito específica que enfrenta desafios psicológicos relacionados á sua dificulade auditiva. Que apesar de todos terem audibilidade preservada nas frequências baixas, encontram desafios sociais e emocionais e precisam de atenção profissional. Apesar de $40 \%$ dos indivíduos do grupo estudo não apresentarem benefício com o uso de próteses auditivas, o uso efetivo das mesmas não demonstrou impacto na qualidade de vida. Os pacientes com perda auditiva pré lingual em função da preservação da audição nunca farão parte da comunidade que faz uso de língua de sinais e parece desenvolver uma comunicação mais eficiente assim como utilizar melhor os mecanismos de ajuste. Os pacientes com perda auditiva pós lingual perdem a fluência na comunicação auditivo-verbal e com isso experienciam maior confusão e instabilidade e portanto têm maior tendência a se privar de participações sociais. Mas não encotraram diferenças estatísticamente significantes entre esses pacientes.

Roland et al. (2016) avaliaram a satisfação e a eficácia dos implantes cocleares híbridos, em 50 pacientes adultos que realizaram a cirurgia com o Nucleus Hybrid L24, em dez diferentes instituições. O protocolo incluiu avaliação pré-cirurgia e um, três, seis e 12 meses após a cirurgia. Realizaram audiometria tonal em campo, reconhecimento de monossílabos e de sentenças, com apresentação a 60 dBNA e com ruído tipo babble com relação sinal ruído de $+5 \mathrm{~dB}$. Para determinar o quanto a audição impacta na qualidade de vida aplicaram o questionário SSQ (Speech, Spatial and Qualities of Hearing Questionnaire). Ao testarem a orelha implantada, observaram uma melhora estatisticamente significante no reconhecimento de palavras $p<0,001$, tanto para os monossílabos (melhora de 35\%) quanto para as sentenças (melhora de $32.0 \%$ ). Pacientes com menor tempo de privação sensorial também obtiveram melhores resultados. Compararam os resultados obtidos com a avaliação audiológica pré- cirurgia na condição do uso de aparelhos auditivos em ambas 
as orelhas e também observaram melhores resultados com $p=0,001$. 48 dos 50 pacientes responderam ao questionário e todos relataram melhora e satisfação. Descreveram 65 eventos adversos em 34 pacientes, 50 destes episódios eram de natureza médica envolvendo tonturas, zumbido, cirurgias na mastoide, e 15 episódios envolvendo o dispositivo, como eletrodos em curto circuito. Concluiram que o sistema híbrido fornece audibilidade nas frequências altas, que é essencial para a boa compreensão de fala, sendo um tratamento novo e efetivo e contribui para melhora na qualidade de vida.

McDonald et al. (2017) descreveram o caso de uma paciente de 57 anos que apresentou perda auditiva neurossensorial profunda, três dias após receber uma dose intravenosa de $135 \mathrm{mg} / \mathrm{m}^{2}$ de paclitaxel, e subsequente dose de cisplatina de $75 \mathrm{mg} / \mathrm{m}^{2}$ para tratamento de câncer de ovário. A avaliação audiológica foi realizada no dia da queixa e constatou-se perda auditiva profunda bilateral com índice de $0 \%$ de discriminação em ambas as orelhas, classificada como ototoxicidade grau 4 segundo os critérios da ASHA. A audição não pôde ser recuperada mesmo após tratamento com esteróides sistêmicos e mudança no protocolo quimioterápico com agentes alternativos. A paciente foi encaminhada como candidata ao implante coclear

\subsection{MAPEAMENTO TONOTÓPICO CORTICAL APÓS PRIVAÇÃO SENSORIAL}

Syka (2002) fez uma revisão sistemática descrevendo os artigos sobre plasticidade do sistema auditivo central após perdas auditivas em humanos e em animais sobretudo durante o período crítico do desenvolvimento e aprendizagem. Comparou diferentes perdas auditivas, desde a ablação unilateral com lesões parciais em animais logo após o nascimento e em animais adultos. Descreveu que a ablação unilateral causa mudanças na representação inclusive da orelha não lesionada. Macacos expostos a ototóxicos tiveram seus córtices auditivos mapeados após 80 a 90 dias e a região das frequências altas estava ocupada por uma representação alargada das frequências vizinhas à frequência de início da lesão. Estudos em humanos 
com exames de imagem mostram que existem regiões no sistema auditivo central que podem ser moduladas e variam positivamente após condicionamento, treinamento e induzem a mudanças tonotópicas neurais. Relatou que o sistema auditivo tem a habilidade de reorganizar suas estruturas e sua função após a perda parcial ou total de seus receptores periféricos, que são muito vulneráveis. Concluiu que o sistema auditivo é flexível e possui potencial para mudanças dinâmicas que podem ser demonstradas através de condicionamento.

Thai-Van et al. (2003) estudaram cinco pacientes com perda auditiva em rampa e com a frequência de corte do início da perda auditiva entre 595 e 2181 $\mathrm{Hz}$. Descreveram que os receptores periféricos tem uma representação cortical topograficamente mapeada e que alterações nos mapas sensoriais nos níveis corticais e subcorticais foram observados após lesões periféricas. Os neurônios que inervam estas regiões se tornaram responsivos a estímulos a regiões próximas ou vizinhas a região lesioanda. Desta forma, estímulos dados aos receptores preservados podem estar sendo atribuídos por engano a outras regiões cocleares e corticais. Descreveram que em pacientes com perda auditiva em rampa acentuada, a presença de zonas mortas cocleares é a condição para a ocorrência da plasticidade auditiva central. Os autores sugeriram que o aumento na diferença do limiar das frequências é um efeito da plasticidade neuronal, pois quando a região coclear que está completamente lesionada (limiar auditivo ausente) é vizinha de uma região apenas parcialmente lesionada (limiar auditivo elevado), existe uma sobrerepresentação central da frequência cujo limiar absoluto está apenas elevado mas não ausente.

Philibert et al. (2005) descreveram que a região cortical que normalmente representaria a área periférica lesionada pela perda auditiva se torna ocupada por uma representação expandida das regiões adjacentes á frequência de início da perda auditiva. As próteses auditivas fornecem novas pistas acústicas aos pacientes com perda auditiva e o aprendizado destes novos sons, que é denominado de aclimatização á intensidade sonora pode ser considerada uma forma de plasticidade. Os autores mediram modificações 
perceptuais e fisiológicas que resultaram do uso de próteses auditivas em pacientes com perda auditiva neurossensorial em rampa. Avaliaram oito pacientes com presbiacusia em quatro diferentes momentos: antes do uso de amplificação sonora, um mês após, três e seis meses após. Realizaram pesquisa de percepção de loudness á 75 dB e 95 dB em $500 \mathrm{~Hz}$ e $2000 \mathrm{~Hz}$ e mediram as respostas no potencial auditivo evocado de tronco encefálico (PEATE). Não encontraram relação estatísticamente significante entre amplitude e latência nas ondas do PEATE mas observaram mudanças entre a avaliação pré e após 6 meses de uso. O uso dos dispositivos aumentou a área dinâmica da audição e diminuiu o recrutamento de loudness, assim como melhorou a capacidade de discriminar intensidades sonoras.

Scheirner \& Winer (2007) estabeleceram que mapas corticais são difusos, variáveis e dependentes de áreas e tarefas para estabelecerem suas configurações. Propuseram a definição de mapa cortical como uma distribuição espacial de informação sensorial numa região cortical, como uma representação ponto a ponto do epitélio dos receptores periféricos. Sugeriram que eles podem ser adaptativos e que são uma ferramenta para organizar sensações através das múltiplas sinapses entre os diferentes sistemas corticais. Relataram que a reprodução da topografia dos receptores periféricos não tem a mesma qualidade ao longo das diferentes áreas corticais. Definiram que o padrão das conexões anatômicas têm papel fundamental na criação, reorganização e plasticidade no desenvolvimento de um novo mapa auditivo cortical.

Guiraud et al. (2007) avaliaram a organização tonotópica cortical em 13 usuários de implante coclear,com no mínimo 3 meses de uso. Descreveram que os resultados obtidos sugerem fortemente que após 3 meses de uso o cortex auditivo apresenta uma reorganização que se assemelha aos mapas de frequência de ouvintes normais, sobretudo no hemisfério ipsilateral. Propuseram que a seletividade de frequências dos neurônios corticais contribui para a discriminação de frequências, de modo que usuários com melhor discriminação entre eletrodos são aqueles com melhor percepção de fala, por 
outro lado quando a alocação de frequências na cóclea não respeita o local de cada frequência no mapa, a percepção de fala é pior.

Izquierdo et al. (2009) fizeram uma revisão sobre a capicidade de reorganização cortical em cérebros adultos como consequência de lesões periféricas ou como resultado de experiências sensoriais adquiridas. Definiram que plasticidade é um mecanisnmo ou um processo ativo que tem inicio por uma mudança nas aferências e que supõe um processo ativo de readaptação frente ás novas condições do meio. Afirmaram que a plasticidade é um processo adaptativo desejável que permite o reparo neuronal após uma lesão e que premite o aprendizado ao longo da vida assim como a adaptação ao meio ambiente. Descreveram que a plasticidade que ocorre após a lesão do órgão receptor periférico provoca uma reorganização no mapa tonotópico pois a região cortical se vê privada de suas aferências normais e passa a ser ocupada por uma representação expandida das zonas adjacentes saudáveis da cóclea.

Thai-Van et al. (2010) investigaram a plasticidade de mapas tonotópicos corticais através da análise de escores de discriminação de frequências em pacientes com perda auditiva em frequências altas. Descreveram que após a lesão periférica, os neurônios com frequências localizadas na região na qual os limiares auditivos estão elevados desenvolvem respostas para frequências próximas ao início da perda auditiva. A mudança neste ajuste (tunning) resulta numa super representação da frequência de início da lesão, resultando numa representação neural alargada. Supondo que a reabilitação com próteses auditivas fosse capaz de aumentar a quantidade de inputs sensoriais impostos pela perda auditiva e desta maneira produzir mudanças neurais no sistema auditivo, investigaram a discriminação de frequências em nove pacientes adultos com perda auditiva em rampa antes e após 1, 3 e 6 meses do uso das próteses. Observaram alteração significante após 1 mês do uso das próteses auditivas. Também relataram que quanto mais jovem, maior a mudança com $p<0,005$. Sugerindo que a amplificação pode reverter a privação sensorial fazendo com que neurônios voltem á sua função normal e permitindo que o mapa tonotópico cortical recupere o mesmo padrão de representação de pacientes normo ouvintes. 
Moerel et al. (2012) utilizaram ressonância magnética funcional e sons naturais que contém uma ampla faixa de frequências para avaliar a representação do som no córtex auditivo. Os autores descreveram que o cérebro humano processa o som primeiramente no receptor periférico onde as bandas de frequências são seletivamente selecionadas. Nas áreas corticais os neurônios com preferência de frequências parecidas se agrupam e formam múltiplos mapas tonotópicos. Estes mapas parecem desencadear representações sensoriais do som em diferentes resoluções temporais e espectrais, que serão utilizadas para o processamento eficiente dos sons ambientais. Avaliaram cinco pacientes adultos sem história de perda auditiva ou distúrbios neurológicos e conseguiram identificar regiões sensíveis à fala ou voz, que ocupam regiões nos mapas próximos á frequências baixas até 1 kHz. Concluíram que a fala e a voz contem mais energia em frequências relativamente baixas, até $1 \mathrm{kHz}$ e isto pode ser uma característica que os distingue de outras categorias de sons.

Reiss et al. (2014) descreveram que no sistema auditivo periférico normal as células ciliadas transformam a energia vibratória em energia elétrica criando mapas espaciais, que são frequência específica e dependem do local na cóclea onde esta transdução ocorre. Se o pico de máxima vibração ocorre na base da cóclea ou no ápice, determinando a tonotopia coclear e deste modo permitindo que um tom puro tenha seu pitch detectado. Avaliaram a plasticidade na percepção do pitch em pacientes usuários de implantes cocleares híbridos. Pois ao posicionar os eletrodos ao longo da cóclea o implante coclear tradicional fornece uma aproximação da informação de frequência. No caso dos implantes híbridos o feixe de eletrodos é colocado entre 8 a 21 milímetros, correspondendo ao local na cóclea de estimulação de frequências não abaixo de 500 a $1500 \mathrm{~Hz}$ e isto leva a uma desorganização tonotópica entre a frequência analizada pelo processador em contraste com a frequência característica das fibras do nervo auditivo. Além do desencontro entre a estimualção elétrica na orelha implantada e acústica na orelha contralateral. Avaliaram onze pacientes adultos, apresentando o estímulo elétrico diretamente no processador de fala e o estimulo acústico na orelha 
contralateral.. Os pacientes foram testados no momento da ativação e depois de 1, 3, 6 e 12 meses. Observaram que o pitch gradualmente se encontra com a frequência estiumulada com diferença estatísticamente significante após $1 \mathrm{e}$ após 3 meses de uso do implante. A correlação entre as mudanças na percepção do pitch e a alocação de frequências indica que a mudança na percepção ocorre como resultado da percepção de discrepâncias entre o estímulo elétrico na orelha implantada e o estímulo acústico na orelha contralateral. Concluíram que as mudanças no mapa cortical no córtex auditivo parecem ocorrer em maior escala do que se imaginava no sistema auditivo maduro.

Chen \& Yuan (2015) relataram que a privação aural pode distorcer mapas tonotópicos, quebrar a integração binaural, reorganizar a rede neural e mudar a transmissão no córtex auditivo primário. Definiram a plasticidade como uma reorganização estrutural e funcional do cérebro para se adaptar ás mudanças no ambiente e ás mudanças fisiológicas do corpo. Concluiram que a reversão da reorganização cortical causada pela privação sensorial permitiu que pacientes com perda auditiva se beneficiassem adequadamente da reabilitação auditiva. 
3 OBJETIVOS 


\section{OBJETIVOS}

Os objetivos do presente trabalho são, identificar:

- a extensão de zonas mortas cocleares após o tratamento oncológico em perdas auditivas em rampa.

- se há benefício da amplificação sonora em pacientes oncológicos com perdas auditivas em rampa,

- a frequência de ocorrência de pacientes que tenham indicação à cirurgia com o implante híbrido.

- a melhor opção na reabilitação auditiva, se com ou sem o uso da limitação de frequências 
4 MATERIAL E MÉTODO 


\section{MATERIAL E MÉTODO}

Estudo prospectivo de corte transversal aprovado pelos Comitês de Ética do HCFMUSP (parecer 1.222.109) e do AC CAMARGO (parecer 2.081.576) para avaliar a contribuição do uso de próteses auditivas sem e com a tecnologia de limitação de frequências, em pacientes com perdas auditivas em rampa após tratamento oncológico (anexos $\mathrm{A}$ e B).

Foram convidados a participar do estudo pacientes acompanhados no Departamento de Audiologia do A.C. Camargo Cancer Center, ao final do tratamento oncológico com perda auditiva descendente em rampa, de maio de 2017 a dezembro de 2018. Tais pacientes realizaram avaliação audiológica como rotina no Departamento de Audiologia e aqueles que preencheram os critérios de seleção foram convidados a participar, e mediante explicação e aceitação dos objetivos e procedimentos envolvidos no estudo assinaram o termo de consentimento livre e esclarecido (anexos C e D).

\section{Seleção da amostra}

Foram considerados elegíveis todos os pacientes de ambos os gêneros, a partir da idade escolar, que preencheram os seguintes critérios:

- Submetidos a tratamento oncológico com derivados da platina e/ou radioterapia em cabeça e pescoço;

- Com presença de perda auditiva descendente com limiares dentro da normalidade ou perdas auditivas de grau leve até $1 \mathrm{kHz}$ e limiares iguais ou superiores a $70 \mathrm{dBNA}$ a partir de $2 \mathrm{kHz}$.

- Timpanometria tipo A

- Ausência das emissões otoacústicas transientes evocadas

- Ausência das emissões otoacústicas produto de distorção,

Foram excluídos do estudo pacientes com má-formação de orelha externa, orelha média ou orelha interna; tumores envolvendo o sistema auditivo, periférico ou central, cirurgia otológica prévia e pacientes incapazes de compreender ou realizar a avaliação proposta. 
Variáveis do Estudo:

- $\quad$ Número de frequências com positividade do teste TEN.

- Limiares auditivos com e sem próteses auditivas.

- $\quad$ Porcentagem de reconhecimento de frases com e sem próteses auditivas, com e sem o uso de limitação de frequências, no silêncio e no ruído

- Porcentagem de reconhecimento de monossílabos com e sem próteses auditivas, com e sem o uso de limitação de frequências, no silêncio e no ruído

- $\quad$ Pontuação no questionário HHIE/HHIA nas duas situações com e sem o uso de limitação de frequências

- $\quad$ Auto-avaliação subjetiva de zero a dez sobre a percepção da contribuição cada um dos dois programas.

\section{Procedimentos}

O fluxograma de procedimentos está apresentado na figura 7. A avaliação audiológica foi composta de imitanciometria, pesquisa das emissões otoacústicas transientes evocadas (EOATE) e produto de distorção (EOAPD), seguidas pela audiometria tonal e vocal. Após esses procedimentos, foi realizado o teste TEN (Threshold Equalizing Noise) para identificação de Zonas Mortas Cocleares (MOORE et al., 2000; MOORE et al., 2004).

A imitanciometria foi realizada para afastar alterações de orelha média que pudessem indicar perdas auditivas condutivas, utilizando-se 0 equipamento Madsen Zodiac 901. O funcionamento do sistema tímpanoossicular foi avaliado por meio da timpanometria e da pesquisa do reflexo estapediano. A timpanometria mede a mobilidade do sistema a variações de pressão. Os timpanogramas foram classificados em três tipos A, B e C (Hall \& Chandler, 1994). O limiar do reflexo estapediano é definido como a menor intensidade do estímulo acústico capaz de provocar uma mudança mínima mensurável na complacência do sistema tímpano-ossicular. 
As emissões otoacústicas foram realizadas com o intuito de avaliar a integridade das células ciliadas externas. Para a realização da pesquisa das emissões otoacústicas foi utilizado o equipamento ILO292. As emissões otoacústicas transientes evocadas são resultado de uma estimulação global da cóclea, por meio de estímulo tipo clique. As emissões otoacústicas produto de distorção são geradas em locais específicos da cóclea, que permitem avaliar melhor a resposta por frequência, sobretudo acima de $4 \mathrm{kHz}$. A literatura aponta que as EAOTE representam uma fonte de reflexão dos cílios que advém de um processo equivalente a uma reflexão linear, enquanto que as EOAPD provém de um processo não linear (Tzanakakis et al., 2016). A ausência das emissões otoacústicas transientes evocadas foi caracterizada por reprodutibilidade global inferior do que 50\% e amplitude de resposta menor ou igual a $3 \mathrm{~dB}$. A ausência das emissões otoacústicas produto de distorção foi caracterizada por registro da amplitude de resposta inferior ou igual a $6 \mathrm{~dB}$ acima do nível de ruído de fundo (NF) (Kós, 2009).

Para a avaliação auditiva foi utilizado o audiômetro Madsen Orbiter 922. $\mathrm{Na}$ audiometria tonal convencional foram determinados os limiares de audibilidade nas frequências de 250 a $8000 \mathrm{~Hz}$. Quando estes limiares encontravam-se acima de 25 dBNA, determinamos os limares tonais por via óssea nas frequências de 500 a $4000 \mathrm{~Hz}$. Limiares até 25 dBNA foram considerados normais, em cada frequência testada (Yantis 1994).

Além disso foi determinado o Limiar de Reconhecimento de Fala (LRF), com palavras trissilábicas, e o Índice Percentual de Reconhecimento de Fala (IPRF), utilizando-se a lista de palavras monossilábicas.

Em seguida, foi aplicado o teste TEN (Threshold Equalizing Noise). O teste implica na repetição da determinação dos limiares audiométricos na presença ipsilateral de ruído. O ruído foi produzido para mascarar uniformemente os limiares das frequências de 125 a $15000 \mathrm{~Hz}$. O nível de ruído é expresso em ERB (Equivalent Rectangular Bandwidth - banda retangular equivalente), para explicar a largura da banda do filtro alcançado pelo TEN e este é calibrado de maneira a equivaler ao nível de pressão sonora do limiar auditivo que está sendo pesquisado. A equivalência faz com que 1 
$E R B=1$ dBNPS, por exemplo, a intensidade de 70dB/ERB é usada para mascarar o limiar de $70 \mathrm{~dB}$. O ruído ERB equivale à média de filtros auditivos calculados em indivíduos jovens normo-ouvintes em intensidades moderadas. O teste TEN é gravado em CD e usado para avaliar os limiares auditivos mascarados ipsilateralmente, somente por via aérea, nas frequências de 500 , 1000, 2000, 3000 e $4000 \mathrm{~Hz}$. Inicialmente, foram medidos os limiares auditivos absolutos, de 250 a $8000 \mathrm{~Hz}$, em seguida, obtivemos os limiares mascarados pelo ruído $\mathrm{ERB}$ de 500 a $4000 \mathrm{~Hz}$. O nível de apresentação do ruído foi estabelecido em $10 \mathrm{~dB}$ acima do limiar encontrado por via aérea, até o limite do equipamento que é 100 dBNA. Foi utilizado audiômetro Madsen Orbiter 922 de dois canais, para o controle independente da intensidade dos estímulos enviados ipsilateralmente com passos de 5 em 5dB (Moore et al., 2003) e fones supra aurais THD 39. Ambas as orelhas foram medidas na mesma sessão em cabine acústica. Foi considerada a presença de Zona Morta Coclear quando o limiar mascarado foi no mínimo $10 \mathrm{~dB}$ acima do limiar absoluto e $10 \mathrm{~dB}$ acima do ruído mascarante. Foi considerada ausência de Zona Morta Coclear quando a mudança do limiar mascarado foi inferior a $10 \mathrm{~dB}$ em relação ao limiar absoluto e/ou não estivesse a 10dB acima do ruído mascarante (Moore, 2004; Jacob et al., 2006; Padilha et al., 2007).

Durante a mesma sessão de avaliação, os pacientes responderam ao questionário Hearing Handicap Inventory for Adults (HHIA), anexo E, ou questionário Hearing Handicap Inventory for Elderly (HHIE), anexo $\mathrm{F}$, adaptados ao português em 1998 (Almeida, 1998), dependendo da idade do paciente. Tais questionários são compostos por 25 questões que têm por objetivo verificar as dificuldades sociais e emocionais relacionadas à perda auditiva. Foram utilizados para verificar as eventuais queixas e dificuldades com relação à audição e seu impacto na qualidade de vida de cada paciente. $\mathrm{O}$ questionário HHIA/HHIE resultou em uma pontuação final classificada em três categorias

- Não há presença de restrição auditiva, com pontuação entre 0 e $16 \%$ 
- $\quad$ Presença de restrição auditiva, leve a moderada, com pontuação entre 18 e $42 \%$;

- $\quad$ Presença de restrição auditiva, grave, com pontuação superior a $42 \%$

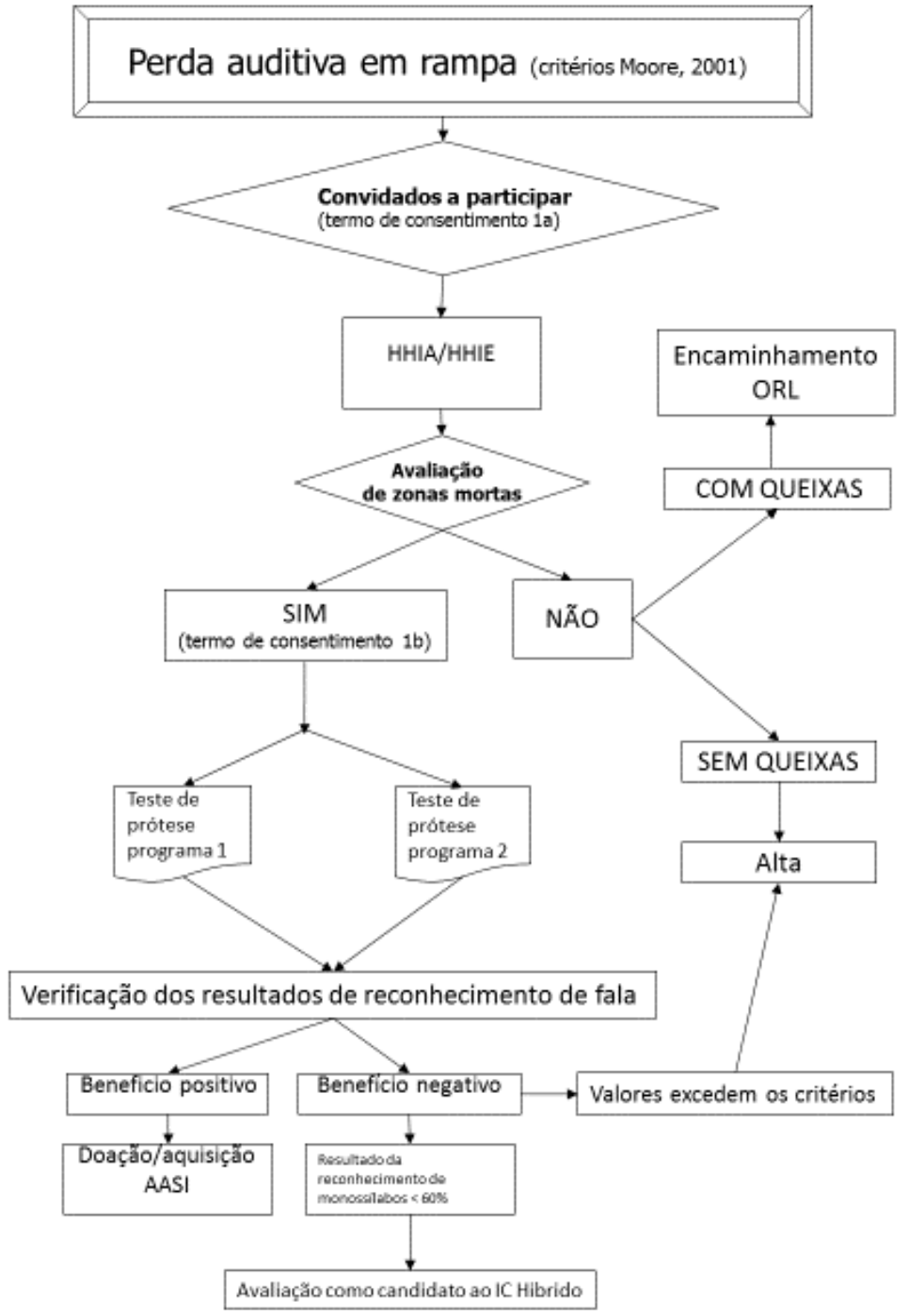

Figura 7. Fluxograma dos procedimentos envolvidos no estudo. 


\section{Reabilitação com Próteses Auditivas}

Após a identificação da perda auditiva e a presença de zonas mortas cocleares, foi apresentado o TCLE (anexo D) e o paciente foi convidado a experimentar a possibilidade de melhorar seu desempenho auditivo, com a adaptação e experiência domiciliar com próteses auditivas, considerando a prescrição do médico otorrinolaringologista. Os pacientes do sistema único de saúde (SUS) foram encaminhados ao ambulatório da Divisão de Otorrinolaringologia do Hospital das Clínicas da Faculdade de Medicina da Universidade de São Paulo e os pacientes privados foram adaptados no Hospital AC Camargo Cancer Center. Todos os pacientes receberam amplificação sonora convencional, com aparelhos retroauriculares Naída III SP da marca Phonak, que possuem saída máxima de 141 dBNPS com ganho máximo de 80 dBNPS e com faixa de frequências de 100 a $6900 \mathrm{~Hz}$, com moldes auriculares adequados à preservação auditiva em frequências baixas. Optamos por esse modelo pois ele está disponível para compra e também para doação pelo Sistema Único de Saúde.

Foram testados dois programas para experiência domiciliar com as próteses auditivas. Uma programação com amplificação estendida ás frequências com a presença de zonas mortas cocleares e outra programação com limitação de frequências com início na frequência inicial fe da zona morta coclear, em $2 \mathrm{kHz}$ conforme protocolo sugerido por Moore (2004). Os pacientes fizeram uso dos programas durante, pelo menos, 15 dias cada um. A ordem de apresentação dos programas com e sem a limitação de frequências foi randomizada (www.randomizer.org).

Após o período de experiência com cada programação foram realizados testes para avaliação do benefício das próteses auditivas, envolvendo:

- Audiometria em campo livre sem as próteses auditivas e com as próteses auditivas só na orelha direita, só na orelha esquerda e em ambas as orelhas. 
- Provas de reconhecimento de fala realizadas em campo livre em cabina acusticamente tratada, com material gravado apresentado a $60 \mathrm{dBSPL}$ (Goffi-Gomez et al., 2004):

- Frases em apresentação aberta no silêncio

- Frases em apresentação aberta no ruído com $\mathrm{SNR}=0 \mathrm{~dB}$

- Monossílabos em apresentação aberta no silêncio

- Monossílabos em apresentação aberta no ruído com SNR $=0 \mathrm{~dB}$

- Questionário HHIA/HHIE

Ao final dos testes de reconhecimento de fala, o paciente definiu sua preferência em relação aos programas com e sem limitação de frequências por meio de uma nota de zero a dez, que refletia o quanto o paciente havia gostado daquela programação. Em que 0 corresponderia a nenhuma melhora ou acréscimo de clareza e naturalidade do som e 10 corresponderia ao máximo de melhora na clareza e naturalidade do som.

Tanto a alocação da programação das próteses auditivas como os testes de percepção de fala foram realizados por um profissional diferente daquele que fez a programação das próteses auditivas, de forma que nem o paciente e nem o examinador sabiam qual programação foi testada (duplo cego).

Após o período de experiência com 0 uso de próteses auditivas convencionais, o processo de avaliação foi finalizado e o paciente pôde optar pela doação dos dispositivos pelo SUS ou a aquisição, em caso de pacientes do setor privado.

Também foram realizados testes das características eletro-acústicas das próteses auditivas que envolveram a validação do ganho em relação às curvasalvo e a verificação do mapeamento de fala através do valor de SII (Speech Inteligibility Index);

Caso o paciente fosse indiferente quanto à preferência por um programa ou outro através da nota, foi escolhido aquele com melhor desempenho nos testes de percepção fala, seguindo a ordem de maior dificuldade (primeiramente monossílabos). Caso o paciente não demonstrasse benefício 
com as próteses em nenhum dos programas, foi proposta a avaliação e explicação do procedimento do implante coclear híbrido.

Caso o paciente não demonstrasse interesse por nenhum dos procedimentos propostos, ele foi encaminhado para treinamento auditivo e acompanhamento na rede município, em unidade básica próxima a sua residência.

Foram considerados critérios de indicação à cirúrgia do implante coclear híbrido ou estimulação eletro-acústica, segundo Woodson et al. (2000): pacientes acima dos 15 anos de idade com limiares auditivos nas frequências de $500 \mathrm{~Hz}$ melhores do que 60 dBNA, e limiares a partir de $2000 \mathrm{~Hz}$ maiores ou iguais a 80, com reconhecimento de monossílabos entre 10\% e 60\% na melhor condição de amplificação para a orelha a ser implantada e não maior do que $80 \%$ na orelha contralateral.

\section{Análise Estatística}

Foram coletadas as seguintes variáveis: limiares audiométricos entre $0,5 \mathrm{kHz}$ e $4 \mathrm{kHz}$ com e sem ruído ERB. Limiares em campo livre, reconhecimento de monossílabos no silêncio e no ruído e reconhecimento de frases no silêncio e no ruído, sem prótese auditiva, com prótese auditiva, com duas programações, em cada orelha separadamente e juntas.

Foram comparados os limiares audiométricos sem e com as próteses auditivas e a compressão de frequências, utilizando um modelo de análise de variância (ANOVA) . Para as frequências entre $0,5 \mathrm{kHz}$ e $4 \mathrm{kHz}$ na orelha direita, foi aplicado o teste não paramétrico de Friedman, uma vez que a distribuição desta variável nessas duas frequências não foi considerada normal.

A pontuação do questionário HHIA/HHIE e a variável nota foram analisadas com um modelo de variância (ANOVA) com medidas repetidas no fator condição, completado pelo teste de múltiplas comparações de Bonferoni.

Para todos os testes foi estabelecido um erro alfa de $5 \%$. Os resultados foram considerados estatisticamente significantes quando $p<0,05$. 
5 RESULTADOS 


\section{RESULTADOS}

Num quadro de 800 pacientes, que fazem acompanhamento audiológico de rotina durante o tratamento oncológico, foram identificados $25 \mathrm{com}$ limiares auditivos iguais ou superiores a 70 dBNA a partir de $2 \mathrm{kHz}$ em pelo menos uma das orelhas. Destes Não foi possível o contato com três deles, dois não compareceram à convocação, e quatro pacientes vieram a óbito.

Entre os 16 pacientes convidados a participar:

Um paciente não quis testar próteses auditivas por achar o molde muito grande e desconfortável. Este paciente é portador de carcinoma de nasofaringe, tendo realizado quimioterapia concomitante à radioterapia e tem problemas de pele no conduto auditivo como sequela do tratamento.

Um paciente recusou-se a experimentar próteses auditivas por não ter queixas auditivas.

Um paciente recusou-se a realizar a avaliação audiológica por achar que ouve bem, ele refere que a dificuldade de compreensão de fala dele na verdade deve-se à má articulação dos falantes.

Uma paciente não conseguiu executar o teste TEN, confundia-se com a presença do mascaramento, não sendo possível determinar os limiares mascarados pelo ruído ERB.

Doze pacientes realizaram o teste de zonas mortas e aceitaram testar as próteses auditivas. Destes, apenas 8 completaram todas as avaliações. Dois pacientes nunca compareceram para início do período de experiência domiciliar e dois pacientes desistiram de experimentar as próteses auditivas após a primeira programação por não quererem dar continuidade aos atendimentos. 
Tabela 1. Dados demográficos

\begin{tabular}{lccccccc}
\hline Identificação & Tumor & Sexo & $\begin{array}{c}\text { Idade na } \\
\text { Avaliação } \\
\text { (anos) }\end{array}$ & $\begin{array}{c}\text { Tempo da } \\
\text { avaliação } \\
\text { após } \\
\text { tratamento } \\
\text { (meses) }\end{array}$ & $\begin{array}{c}\text { Quimoterapia } \\
\text { CDDP } \\
\left(\mathrm{mg} / \mathrm{m}^{2}\right)\end{array}$ & $\begin{array}{c}\text { Radioterapia } \\
\text { (cGy) }\end{array}$ & $\begin{array}{c}\text { AASI } \\
\text { Prévio }\end{array}$ \\
\hline ID 1 & Nasofaringe & feminino & 48 & 192 & 360 & 5040 & Sim \\
ID 2 & Palato & masculino & 62 & 12 & 300 & 5040 & Não \\
ID 3 & Estômago & feminino & 78 & 2 & $395^{*}$ & Não & Não \\
ID 4 & Retinoblastoma & masculino & 20 & 216 & 600 & 4200 & Sim \\
ID 5 & Retinoblastoma & feminino & 19 & 204 & 1020 & 5000 & Sim \\
ID 6 & Nasofaringe & masculino & 50 & 108 & 360 & 5040 & Não \\
ID 7 & Retinoblastoma & feminino & 28 & 168 & 1200 & 4200 & Não \\
ID 8 & Osteosarcoma & masculino & 40 & 288 & 1200 & Não & Não \\
\hline
\end{tabular}

legenda: * quimioterapia interrompida por toxicidade

A tabela 1 mostra que a média de idade na avaliação audiológica variou entre 19 e 78 anos, com média de 43,12 anos. Em nossa amostra encontramos três pacientes com tumores de cabeça e pescoço e três pacientes com tumores de retina que também foram submetidos a tratamento radioterápico em cabeça e pescoço. A idade na avaliação audiológica variou de 2 a 288 meses, sendo que entre os três pacientes que haviam experimentado próteses auditivas anteriormente, o tempo de perda auditiva após o tratamento era superior a 190 meses.

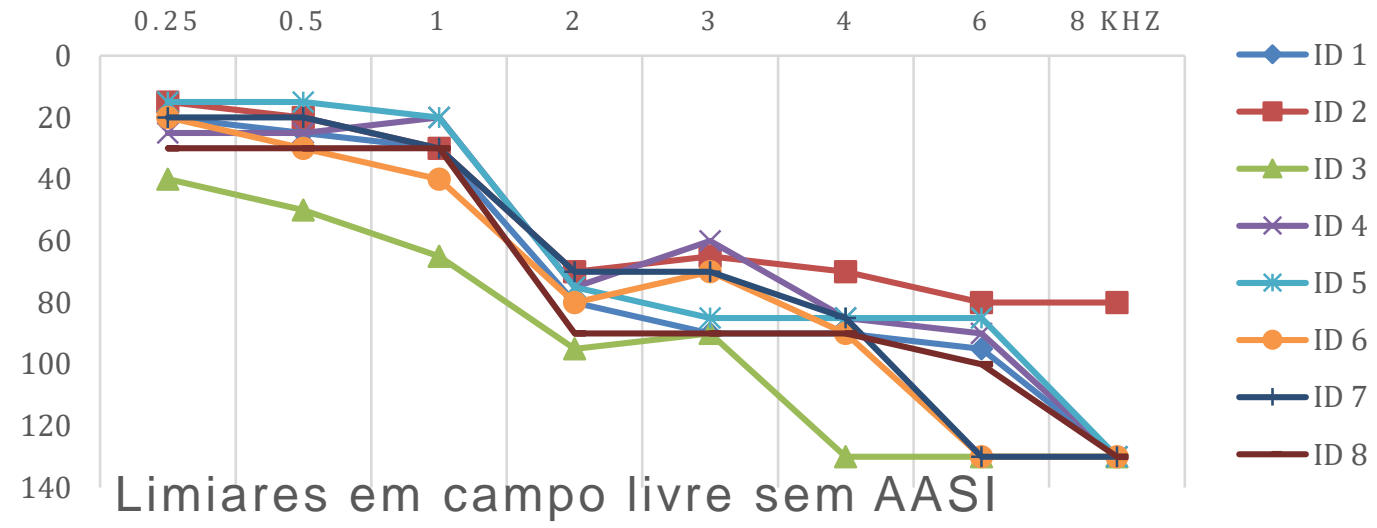

Figura 8. Limiares auditivos em campo livre sem Próteses Auditivas. 
Na figura 8 é possível observar a configuração da perda auditiva e os limiares auditivos dos pacientes participantes do estudo.

Tabela 2 - Resultado do teste TEN para cada paciente.

\begin{tabular}{cccccccccccc}
\hline & & $\mathbf{0 , 5} \mathbf{~ k H z}$ & \multicolumn{1}{c}{$\mathbf{1} \mathbf{k H z}$} & \multicolumn{2}{c}{$\mathbf{2} \mathbf{k H z}$} & \multicolumn{2}{c}{$\mathbf{3} \mathbf{k H z}$} & \multicolumn{2}{c}{$\mathbf{4} \mathbf{k H z}$} \\
\hline & & OD & OE & OD & OE & OD & OE & OD & OE & OD & OE \\
\hline ID 1 & & & & & & & & & & & \\
\hline & LA & 20 & 15 & 20 & 10 & 70 & 70 & 85 & 90 & 90 & 90 \\
\hline & LM & 35 & 45 & 35 & 45 & 80 & 90 & AUS & AUS & AUS & AUS \\
\hline
\end{tabular}

ID 2

\begin{tabular}{ccccccccccc}
\hline LA & 20 & 30 & 10 & 20 & 70 & 70 & 80 & 100 & 90 & AUS \\
\hline LM & 40 & 70 & 25 & 50 & 90 & 90 & 120 & AUS & AUS & AUS \\
\hline
\end{tabular}

ID 3

\begin{tabular}{cccccccccccc}
\hline & LA & 40 & 35 & 50 & 50 & 85 & 85 & 100 & 110 & 105 & 110 \\
\hline & LM & 70 & 60 & 70 & 85 & 120 & AUS & AUS & AUS & AUS & AUS \\
\hline ID 4 & & & & & & & & & & & \\
\hline & LA & 10 & 25 & 15 & 20 & 50 & 70 & 60 & 80 & 80 & 100 \\
\hline LM & 20 & 30 & 40 & 40 & 80 & 100 & 90 & 110 & AUS & AUS \\
\hline
\end{tabular}

ID 5

\begin{tabular}{ccccccccccc}
\hline LA & 10 & 25 & 20 & 15 & 85 & 80 & 90 & 80 & 85 & 85 \\
\hline LM & 50 & 40 & 60 & 60 & AUS & AUS & AUS & AUS & AUS & AUS \\
\hline
\end{tabular}

ID 6

\begin{tabular}{ccccccccccc}
\hline LA & 25 & 25 & 20 & 30 & 70 & 80 & 80 & 90 & 90 & 100 \\
\hline LM & 50 & 60 & 40 & 50 & 100 & 120 & 100 & AUS & AUS & AUS \\
\hline
\end{tabular}

ID 7

\begin{tabular}{ccccccccccc}
\hline LA & 10 & 10 & 20 & 20 & 65 & 70 & 80 & 75 & 85 & 80 \\
\hline LM & 30 & 35 & 40 & 70 & 75 & 80 & AUS & AUS & AUS & AUS \\
\hline
\end{tabular}

ID 8

\begin{tabular}{ccccccccccc}
\hline LA & 25 & 15 & 30 & 45 & 100 & 90 & 100 & 105 & 105 & 110 \\
\hline LM & 15 & 15 & 30 & 45 & AUS & 110 & AUS & AUS & AUS & AUS
\end{tabular}

Legenda: LA. Limiar absoluto; LM: Limiar mascarado; AUS: resposta ausente 
A tabela 2 mostra que a maioria dos pacientes apresentou variação superior a $10 \mathrm{~dB}$ entre limiar absoluto e limiar mascarado, indicando a presença de zonas mortas cocleares em todas as frequências. O paciente ID 8 não apresentou zonas mortas nas frequências de 0,5 e $1 \mathrm{kHz}$, e o paciente ID 4 não apresentou zonas mortas cocleares na frequência de $0,5 \mathrm{kHz}$ na orelha direita.

Tabela 3. Medidas descritivas dos limiares auditivos com e sem próteses auditivas (em dB NA) por frequência $(\mathrm{em} \mathrm{Hz})$ em ambas as orelhas.

\begin{tabular}{|c|c|c|c|c|c|c|c|}
\hline Frequência & Condição & Média & $\begin{array}{l}\text { Desvio } \\
\text { padrão }\end{array}$ & Mínimo & Mediana & Máximo & Valor-p \\
\hline \multirow[t]{3}{*}{$0,25 \mathrm{kHz}$} & Sem próteses auditivas & 23,1 & 8,4 & 15 & 20,0 & 40 & 0,378 \\
\hline & Com limitação de frequências & 19,4 & 6,8 & 10 & 22,5 & 25 & \\
\hline & Sem limitação de frequências & 21,9 & 7,5 & 10 & 22,5 & 35 & \\
\hline \multirow[t]{3}{*}{$0,5 \mathrm{kHz}$} & Sem próteses auditivas & 26,9 & 10,7 & 15 & 25,0 & 50 & 0,163 \\
\hline & Com limitação de frequências & 21,9 & 7,0 & 10 & 20,0 & 35 & \\
\hline & Sem limitação de frequências & 20,6 & 5,7 & 10 & 22,5 & 25 & \\
\hline \multirow[t]{3}{*}{$1 \mathrm{kHz}$} & Sem próteses auditivas & 33,1 & 14,4 & 20 & 30,0 & 65 & 0,013 \\
\hline & Com limitação de frequências & 23,8 & 8,8 & 15 & 20,0 & 40 & \\
\hline & Sem limitação de frequências & 25,6 & 7,3 & 15 & 25,0 & 40 & \\
\hline \multirow[t]{3}{*}{$2 \mathrm{kHz}$} & Sem próteses auditivas & 79,4 & 9,0 & 70 & 77,5 & 95 & $<0,001$ \\
\hline & Com limitação de frequências & 39,4 & 12,1 & 20 & 40,0 & 55 & \\
\hline & Sem limitação de frequências & 38,8 & 14,1 & 25 & 32,5 & 65 & \\
\hline \multirow[t]{3}{*}{$3 \mathrm{kHz}$} & Sem próteses auditivas & 77,5 & 12,5 & 60 & 77,5 & 90 & $<0,001$ \\
\hline & Com limitação de frequências & 44,4 & 14,3 & 25 & 45,0 & 65 & \\
\hline & Sem limitação de frequências & 38,8 & 9,2 & 30 & 35,0 & 55 & \\
\hline \multirow[t]{3}{*}{$4 \mathrm{kHz}$} & Sem próteses auditivas & 90,6 & 17,2 & 70 & 87,5 & 130 & $<0,001$ \\
\hline & Com limitação de frequências & 50,0 & 10,4 & 30 & 50,0 & 65 & \\
\hline & Sem limitação de frequências & 52,5 & 32,1 & 30 & 42,5 & 130 & \\
\hline \multirow[t]{3}{*}{$6 \mathrm{kHz}$} & Sem próteses auditivas & 105,0 & 21,6 & 80 & 97,5 & 130 & $<0,001$ \\
\hline & Com limitação de frequências & 56,3 & 31,4 & 25 & 50,0 & 130 & \\
\hline & Sem limitação de frequências & 55,0 & 30,9 & 35 & 47,5 & 130 & \\
\hline \multirow[t]{3}{*}{$8 \mathrm{kHz}$} & Sem próteses auditivas & 123,8 & 17,7 & 80 & 130,0 & 130 & 0,005 \\
\hline & Com limitação de frequências & 76,3 & 35,3 & 45 & 65,0 & 130 & \\
\hline & Sem limitação de frequências & 73,8 & 38,1 & 30 & 65,0 & 130 & \\
\hline
\end{tabular}


A Tabela 3 mostra a variação dos limiares auditivos em campo livre, com ambas as orelhas, nas condições, sem próteses auditivas, com próteses auditivas com e sem limitação de frequências. Não encontramos diferença estatísticamente significante entre as condições nas frequências de 2.5 e 0,5 kHz. Mas encontramos diferença estatísticamente significante á partir de $1 \mathrm{kHz}$.

Tabela 4. Medidas descritivas dos limiares auditivos com próteses auditivas (em dB NA) por frequência $(\mathrm{em} \mathrm{Hz})$ na orelha direita nas condições estudadas.

\begin{tabular}{|c|c|c|c|c|c|c|c|}
\hline Frequência & Condição & Média & $\begin{array}{l}\text { Desvio } \\
\text { padrão }\end{array}$ & Mínimo & Mediana & Máximo & Valor-p \\
\hline \multirow[t]{2}{*}{$0,25 \mathrm{kHz}$} & Com limitação de frequências & 23,1 & 8,4 & 10 & 22,5 & 35 & 0,685 \\
\hline & Sem limitação de frequências & 21,9 & 3,7 & 20 & 20,0 & 30 & \\
\hline \multirow[t]{2}{*}{$0,5 \mathrm{kHz}$} & Com limitação de frequências & 24,4 & 9,0 & 10 & 22,5 & 40 & $>0,999$ \\
\hline & Sem limitação de frequências & 23,1 & 4,6 & 20 & 20,0 & 30 & \\
\hline \multirow[t]{2}{*}{$1 \mathrm{kHz}$} & Com limitação de frequências & 27,5 & 10,0 & 20 & 25,0 & 50 & 0,279 \\
\hline & Sem limitação de frequências & 30,6 & 9,0 & 15 & 32,5 & 40 & \\
\hline \multirow[t]{2}{*}{$2 \mathrm{kHz}$} & Com limitação de frequências & 44,4 & 15,7 & 20 & 47,5 & 70 & $>0,999$ \\
\hline & Sem limitação de frequências & 44,4 & 14,5 & 30 & 40,0 & 70 & \\
\hline \multirow[t]{2}{*}{$3 \mathrm{kHz}$} & Com limitação de frequências & 46,3 & 12,5 & 30 & 45,0 & 70 & 0,644 \\
\hline & Sem limitação de frequências & 48,1 & 11,3 & 30 & 50,0 & 60 & \\
\hline \multirow[t]{2}{*}{$4 \mathrm{kHz}$} & Com limitação de frequências & 58,1 & 12,5 & 40 & 57,5 & 80 & 0,059 \\
\hline & Sem limitação de frequências & 58,1 & 32,6 & 30 & 47,5 & 130 & \\
\hline \multirow[t]{2}{*}{$6 \mathrm{kHz}$} & Com limitação de frequências & 65,6 & 27,1 & 50 & 55,0 & 130 & $>0,999$ \\
\hline & Sem limitação de frequências & 65,6 & 28,8 & 35 & 57,5 & 130 & \\
\hline \multirow[t]{2}{*}{$8 \mathrm{kHz}$} & Com limitação de frequências & 91,3 & 33,6 & 50 & 80,0 & 130 & 0,868 \\
\hline & Sem limitação de frequências & 88,8 & 36,8 & 40 & 80,0 & 130 & \\
\hline
\end{tabular}


Tabela 5 Medidas descritivas dos limiares auditivos com próteses auditivas (em dB NA) por frequência $(\mathrm{em} \mathrm{Hz})$ na orelha esquerda nas condições estudadas.

\begin{tabular}{|c|c|c|c|c|c|c|c|}
\hline Frequência & Condição & Média & $\begin{array}{l}\text { Desvio } \\
\text { padrão }\end{array}$ & Mínimo & Mediana & Máximo & Valor-p \\
\hline \multirow[t]{2}{*}{$0,25 \mathrm{kHz}$} & Com limitação de frequências & 20,6 & 8,2 & 10 & 22,5 & 30 & 0,626 \\
\hline & Sem limitação de frequências & 21,9 & 4,6 & 15 & 20,0 & 30 & \\
\hline \multirow[t]{2}{*}{$0,5 \mathrm{kHz}$} & Com limitação de frequências & 20,6 & 7,3 & 10 & 22,5 & 30 & 0,170 \\
\hline & Sem limitação de frequências & 24,4 & 4,2 & 20 & 25,0 & 30 & \\
\hline \multirow[t]{2}{*}{$1 \mathrm{kHz}$} & Com limitação de frequências & 33,1 & 9,6 & 25 & 30,0 & 50 & 0,286 \\
\hline & Sem limitação de frequências & 28,1 & 5,9 & 20 & 30,0 & 35 & \\
\hline \multirow[t]{2}{*}{$2 \mathrm{kHz}$} & Com limitação de frequências & 50,0 & 17,7 & 25 & 52,5 & 75 & 0,785 \\
\hline & Sem limitação de frequências & 50,6 & 15,5 & 30 & 50,0 & 70 & \\
\hline \multirow[t]{2}{*}{$3 \mathrm{kHz}$} & Com limitação de frequências & 53,8 & 18,5 & 30 & 55,0 & 90 & 0,342 \\
\hline & Sem limitação de frequências & 58,8 & 21,8 & 25 & 60,0 & 90 & \\
\hline \multirow[t]{2}{*}{$4 \mathrm{kHz}$} & Com limitação de frequências & 70,0 & 26,2 & 40 & 65,0 & 130 & 0,703 \\
\hline & Sem limitação de frequências & 68,1 & 29,1 & 40 & 62,5 & 130 & \\
\hline \multirow[t]{2}{*}{$6 \mathrm{kHz}$} & Com limitação de frequências & 75,0 & 28,0 & 40 & 70,0 & 130 & $>0,999$ \\
\hline & Sem limitação de frequências & 75,0 & 29,2 & 35 & 75,0 & 130 & \\
\hline \multirow[t]{2}{*}{$8 \mathrm{kHz}$} & Com limitação de frequências & 96,9 & 28,0 & 65 & 82,5 & 130 & 0,426 \\
\hline & Sem limitação de frequências & 107,5 & 32,4 & 50 & 130,0 & 130 & \\
\hline
\end{tabular}

As tabelas 4 e 5 mostram o limiar auditivo por frequência em cada programação na orelha direita e esquerda, repectivamente. Não encontramos diferença estatísticamente significante entre as médias dos limiares auditivos, nas duas condições com e sem limitação de frequências para ambas as orelhas (valores- $p \geq 0,059$ e 0,170 ). No entanto é possível observar melhora dos limiares auditivos com próteses auditivas, nas duas condições, com e sem limitação de frequências. 
Tabela 6. Medidas descritivas da porcentagem de acertos (\%) para os testes monossílabos no silêncio, monossílabos no ruído com relação sinal/ruído $=0 \mathrm{~dB}(\mathrm{SNR}=0 \mathrm{~dB})$, frases no silêncio e frases no ruído com relação sinal/ruído $=0 \mathrm{~dB}(\mathrm{SNR}=0 \mathrm{~dB})$, em ambas as orelhas, com e sem próteses auditivas.

\begin{tabular}{cccccccc}
\hline \multirow{2}{*}{ Teste } & Condição & Média & $\begin{array}{c}\text { Desvio } \\
\text { padrão }\end{array}$ & Mínimo & Mediana & Máximo Valor-p \\
\hline \multirow{2}{*}{ Monossílabos } & Sem próteses auditivas & 62,5 & 30,8 & 16 & 64 & 96 & 0,522 \\
& Com limitação de frequências & 66,5 & 30,0 & 12 & 72 & 96 & \\
& Sem limitação de frequências & 60,5 & 22,6 & 16 & 64 & 88 & \\
\hline \multirow{2}{*}{ Monossílabos SNR=0 } & Sem próteses auditivas & 41,0 & 35,6 & 0 & 34 & 96 & 0,627 \\
& Com limitação de frequências & 49,0 & 18,7 & 8 & 56 & 64 & \\
& Sem limitação de frequências & 46,5 & 23,0 & 12 & 52 & 76 & \\
\hline \multirow{2}{*}{ Frases } & Sem próteses auditivas & 97,5 & 7,1 & 80 & 100 & 100 & 0,368 \\
& Com limitação de frequências & 100,0 & 0,0 & 100 & 100 & 100 & \\
& Sem limitação de frequências & 97,5 & 7,1 & 80 & 100 & 100 & \\
\hline \multirow{2}{*}{ Frases SNR=0 0} & Sem próteses auditivas & 90,0 & 9,3 & 70 & 90 & 100 & 0,210 \\
& Com limitação de frequências & 73,8 & 22,6 & 40 & 75 & 100 & \\
& Sem limitação de frequências & 67,5 & 38,1 & 10 & 85 & 100 & \\
\hline
\end{tabular}

A tabela 6 mostra a melhora na porcentagem no reconhecimento de monossílabos no ruído, na condição com próteses auditivas, sem diferença estatísticamente significante. Pode-se observar que o reconhecimento de frases, tanto no silêncio como no ruído apresenta bons resultados, mesmo sem próteses auditivas. 
Tabela 7. Medidas descritivas porcentagem de acertos (\%) para os testes monossílabos no silêncio, monossílabos no ruído com relação sinal/ruído $=0 \mathrm{~dB}(S N R=0)$ frases no silêncio e frases no ruído com relação sinal/ruído $=0 \mathrm{~dB} S N R=0$ ) na orelha direita nas duas condições de amplificação estudadas.

\begin{tabular}{clcccccc}
\hline \multirow{2}{*}{ Teste } & \multicolumn{1}{c}{ Condição } & Média & $\begin{array}{c}\text { Desvio } \\
\text { padrão }\end{array}$ & Mínimo & Mediana & Máximo & Valor-p \\
\hline \multirow{2}{*}{ Monossílabos } & Com limitação de frequências & 63,0 & 28,0 & 16 & 70 & 96 & 0,219 \\
& Sem limitação de frequências & 58,5 & 27,4 & 16 & 66 & 88 & \\
\hline \multirow{2}{*}{ Monossílabos SNR=0 } & Com limitação de frequências & 49,0 & 25,8 & 8 & 56 & 76 & 0,235 \\
& Sem limitação de frequências & 41,5 & 24,3 & 4 & 44 & 68 & \\
\hline \multirow{2}{*}{ Frases } & Com limitação de frequências & 95,0 & 14,1 & 60 & 100 & 100 & $>0,999$ \\
& Sem limitação de frequências & 95,0 & 9,3 & 80 & 100 & 100 & \\
\hline \multirow{2}{*}{ Frases SNR=0 } & Com limitação de frequências & 60,0 & 18,5 & 40 & 55 & 90 & 0,708 \\
& Sem limitação de frequências & 55,0 & 27,3 & 0 & 55 & 80 & \\
\hline
\end{tabular}

Tabela 8. Medidas descritivas da porcentagem de acertos (\%) para os testes monossílabos no silêncio, monossílabos no ruído com relação sinal/ruído $=0 \mathrm{~dB}(\mathrm{SNR}=0 \mathrm{~dB})$, Frases no silêncio e Frases no ruído com relação sinal/ruído $=0 \mathrm{~dB}(\mathrm{SNR}=0 \mathrm{~dB})$, na orelha esquerda nas duas condições de amplificação estudadas.

\begin{tabular}{clcccccc}
\hline \multirow{2}{*}{ Teste } & \multicolumn{1}{c}{ Condição } & Média & $\begin{array}{c}\text { Desvio } \\
\text { padrão }\end{array}$ & Mínimo & Mediana & Máximo & Valor-p \\
\hline \multirow{2}{*}{ Monossílabos } & Com limitação de frequências & 58,0 & 30,2 & 12 & 58 & 92 & 0,152 \\
& Sem limitação de frequências & 63,8 & 31,6 & 4 & 74 & 90 & \\
\hline \multirow{2}{*}{ Monossílabos SNR=0 } & Com limitação de frequências & 44,5 & 23,8 & 8 & 52 & 64 & 0,304 \\
& Sem limitação de frequências & 39,0 & 27,0 & 0 & 44 & 68 & \\
\hline \multirow{2}{*}{ Frases } & Com limitação de frequências & 96,3 & 7,4 & 80 & 100 & 100 & 0,451 \\
& Sem limitação de frequências & 98,8 & 3,5 & 90 & 100 & 100 & \\
\hline \multirow{2}{*}{ Frases SNR=0 } & Com limitação de frequências & 66,3 & 25,6 & 30 & 65 & 100 & 0,680 \\
& Sem limitação de frequências & 60,0 & 28,3 & 20 & 70 & 100 & \\
\hline
\end{tabular}

As Tabelas 7 e 8 descrevem os acertos nos testes de percepção de fala em cada orelha nas diferentes programações. Não encontramos diferença estatisticamente significante entre as duas condições com e sem limitação de 
frequências. (valores- $p \geq 0,219$ e 0,152 , respectivamente) tanto para a orelha direita quanto para a orelha esquerda. Foi possível observar que a média de reconhecimento de monossílabos no silêncio varia entre $58 \%$ e $63 \%$ e no ruído entre $39 \%$ e $49 \%$.

Tabela 9. Medidas descritivas da variável escore HHIA por condição

\begin{tabular}{cccccccc}
\hline Condição & Média & $\begin{array}{c}\text { Desvio } \\
\text { padrão }\end{array}$ & Mínimo & Mediana & Máximo & Valor-p \\
\hline Sem próteses auditivas & 69,8 & 14,3 & 48 & 66 & 88 & 0,301 \\
Com limitação de frequências & 65,3 & 22,4 & 42 & 60 & 98 & \\
Sem limitação de frequências & 66,0 & 21,5 & 42 & 60 & 98 & \\
\hline
\end{tabular}

Legenda. HHIA. Hearing handicap Inventory for the Elderly.

A Tabela 9 mostra também que não houve diferença estatisticamente significante entre as três situações testadas, com escore no questionário HHIA semelhante. Nota-se melhora do escore com próteses auditivas mas ainda os pacientes apresentaram valores em média superiores a $42 \%$.

Tabela 10. Medidas descritivas da variável nota por condição

\begin{tabular}{cccccccc}
\hline Condição & Média & $\begin{array}{c}\text { Desvio } \\
\text { padrão }\end{array}$ & Mínimo & Mediana & Máximo Valor-p \\
\hline Com limitação de frequências & 7,9 & 1,6 & 6 & 7,5 & 10 & 0,244 \\
Sem limitação de frequências & 7,1 & 1,8 & 4 & 7,5 & 10 & \\
\hline
\end{tabular}

A Tabela 10 mostra que não houve diferença na nota atribuída subjetivamente pelo paciente ao final de cada programação. A nota atribuída à ambas as programações é muito semelhante, ligeiramente superior na condição com limitação de frequências. Todos os pacientes da amostra preferiram usar esta programação. 
Tabela 11 - Valor do Speech Inteligibility Index (em \%) para sons de entrada de 55, 65 e 75 dBNA, respectivamente, nas condições sem e com limitação de frequências por orelha e valor do datallogin com média de uso em horas por dia.

\begin{tabular}{|c|c|c|c|c|c|}
\hline $\begin{array}{c}\text { Paciente/ } \\
\text { Condição testada }\end{array}$ & Orelha & 55dBNA & $\begin{array}{c}65 \mathrm{dBNA} \\
\% \text { SII } \\
\end{array}$ & $75 \mathrm{dBNA}$ & $\begin{array}{c}\text { Datalogging } \\
\text { Horas/dia }\end{array}$ \\
\hline \multicolumn{6}{|l|}{ ID 5} \\
\hline \multirow[t]{2}{*}{ Sem Limitação de Frequências } & OD & - & - & - & \\
\hline & OE & - & - & - & \\
\hline \multirow[t]{2}{*}{ Com Limitação de Frequências } & OD & - & - & - & \\
\hline & OE & 50 & 48 & 59 & 1 \\
\hline \multicolumn{6}{|l|}{ ID 7} \\
\hline \multirow[t]{2}{*}{ Sem Limitação de Frequências } & OD & 56 & 55 & 71 & \\
\hline & OE & 57 & - & - & \\
\hline \multirow[t]{2}{*}{ Com Limitação de Frequências } & OD & 34 & 34 & 42 & 1 \\
\hline & OE & 26 & 37 & 52 & 1 \\
\hline \multicolumn{6}{|l|}{ ID 8} \\
\hline \multirow[t]{2}{*}{ Sem Limitação de Frequências } & OD & 25 & 33 & 42 & \\
\hline & OE & 38 & 38 & 52 & \\
\hline \multirow[t]{2}{*}{ Com Limitação de Frequências } & OD & 34 & 34 & 42 & 0,1 \\
\hline & OE & 26 & 37 & 52 & 1 \\
\hline
\end{tabular}

Legenda: SII. Speech Inteligibility Index

A Tabela 11 evidencia a baixa quantidade de horas de uso dos dispositivos, com pouca variação entre os pacientes. Também foi possível observar o valor de SSI inferior a 60\% para sons de entrada de $65 \mathrm{~dB}$, mesmo valor utilizado nos testes de reconhecimento de fala. Confirmando a pouca compreeensão de fala, em ambas as orelhas com ambas as programações.

Tabela 12. Número de pacientes que optaram pela programação com e sem limitação de frequências acionada

\begin{tabular}{lc}
\hline & $\mathrm{N}(\%)$ \\
\cline { 2 - 2 } OPÇÃO POR AASI & $8(100)$ \\
Com limitação de frequências & $8(100)$ \\
Sem limitação de frequências & $0(0)$ \\
\hline
\end{tabular}


A tabela 12 mostrou que todos os pacientes preferiram usar a programação com limitação de frequências acionada.

Tabela 13. Valor da porcentagem de acertos do reconhecimento de frases e monossílabos (em \%) no silêncio sem AASI apresentados a 60 dBNA em campo livre, em condição binaural.

\begin{tabular}{ccc}
\hline Pacientes & $\begin{array}{c}\text { Reconhecimento } \\
\text { de } \\
\text { frases } \\
(\%)\end{array}$ & $\begin{array}{c}\text { Reconhecimento } \\
\text { de } \\
\text { monossílabos } \\
(\%)\end{array}$ \\
\hline ID 1 & 100 & 92 \\
\hline ID 2 & 100 & 68 \\
\hline ID 3 & 80 & 20 \\
\hline ID 4 & 100 & 96 \\
\hline ID 5 & 100 & 60 \\
\hline ID 6 & 100 & 60 \\
\hline ID 7 & 100 & 60 \\
\hline ID 8 & 90 & 84 \\
\hline
\end{tabular}

A Tabela 13 mostra o bom reconhecimento de fala no silêncio sem o uso de próteses auditivas, sobretudo para a variável frases, indicando que pussuem boa audição residual. 
Tabela 14. Valor da porcentagem de acertos do reconhecimento de monossílabos (em \%) com AASI apresentados a 60 dBNA, nas duas condições estudadas, para a identificação da indicação do implante coclear híbrido ou estimulação eletro-acústica em cada uma das orelhas.

\begin{tabular}{|c|c|c|c|c|}
\hline \multirow[t]{2}{*}{ ID } & & \multicolumn{2}{|c|}{$\begin{array}{c}\text { Reconhecimento } \\
\text { de monossílabos } \\
(\%)\end{array}$} & \multirow[t]{2}{*}{$\begin{array}{c}\text { Uso } \\
\text { prévio } \\
\text { de } \\
\text { AASI }\end{array}$} \\
\hline & & OD & $\mathrm{OE}$ & \\
\hline \multirow[t]{2}{*}{1} & Com limitação de frequências & 96 & 88 & \\
\hline & Sem limitação de frequências & 88 & 88 & Sim \\
\hline \multirow[t]{2}{*}{2} & Com limitação de frequências & 76 & 52 & \\
\hline & Sem limitação de frequências & 76 & 68 & Não \\
\hline \multirow[t]{2}{*}{3} & Com limitação de frequências & 16 & 12 & \\
\hline & Sem limitação de frequências & 16 & 4 & Não \\
\hline \multirow[t]{2}{*}{4} & Com limitação de frequênci56as & 88 & 92 & \\
\hline & Sem limitação de frequências & 84 & 88 & Sim \\
\hline \multirow[t]{2}{*}{5} & Com limitação de frequências & 64 & 60 & \\
\hline & Sem limitação de frequências & 76 & 80 & Sim \\
\hline \multirow[t]{2}{*}{6} & Com limitação de frequências & 76 & 80 & \\
\hline & Sem limitação de frequências & 56 & 90 & Não \\
\hline \multirow[t]{2}{*}{7} & Com limitação de frequências & 60 & 56 & \\
\hline & Sem limitação de frequências & 48 & 64 & Não \\
\hline \multirow[t]{2}{*}{8} & Com limitação de frequências & 28 & 20 & \\
\hline & Sem limitação de frequências & 24 & 28 & Não \\
\hline
\end{tabular}

A Tabela 14 mostra que dois pacientes apresentaram reconhecimento de monossílabos entre $20 \%$ e $60 \%$, atingindo a indicação para realização da cirurgia do implante coclear híbrido em ambas as orelhas, e outros 2 pacientes apresentaram critério de indicação para realização da cirurgia do implante coclear híbrido em uma das orelhas. Uma paciente atingiu valores de reconhecimento de monossílabos entre $4 \%$ e $16 \%$, sendo candidata á realização de cirurgia com implante coclear convencional.Também é possível notar que os pacientes que fizeram uso prévio de AASI apresentaram valores melhores no reconhecimento de monossílabos, sugerindo que quando há benefício, o uso é efetivo. 
6 DISCUSSÃO 


\section{DISCUSSÃO}

A qualidade de vida, o acolhimento e a possibilidade de oferecer diversas opções de reabilitação devem ser nossa preocupação constante diante do paciente oncológico, tanto durante o tratamento como no acompanhamento posterior.

Em nosso trabalho buscamos embasar a conduta para a reabilitação auditiva nos casos com perda auditiva em rampa ao final do tratamento oncológico. Para isso estudamos a frequência de ocorrência de zonas mortas cocleares, apresentamos as opções de uso de próteses auditvas com e sem o recurso da limitação de frequências, bem como buscamos a frequência de ocorrência de candidatos à estimulação eletro-acústica como mais uma proposta de reabilitação auditiva.

Nossa casuística foi composta por 3 pacientes com tumores de cabeça e pescoço e 3 pacientes com tumores oculares submetidos a quimio e radioterapia e 2 pacientes com tumores em outros sítios, submetidos apenas à quimioterapia (Tabela 1). A dose de quimioterapia foi variável, sendo que a perda auditiva foi semelhante entre os pacientes (figura 8 ).

A literatura reporta de presença de zonas mortas cocleares nas perdas auditivas em rampa em ambas as orelhas variando entre 1,8\% (Vinay e Moore, 2007) até 92\% (Jacob et al., 2006). Nós encontramos presença de zonas mortas cocleares em todos os pacientes, inclusive nas frequências de $500 \mathrm{e}$ $1000 \mathrm{~Hz}$ (Tabela 2), cujos limiares absolutos encontravam-se melhores do que $70 \mathrm{~dB}$, referência indicativa de presença de zonas mortas cocleares critério proposto por Moore (2004). Esse fato nos induziu a preferir o termo zonas irresponsivas para as zonas mortas cocleares, pois acreditamos que, sobretudo nestas frequências, as células ciliadas estejam presentes, mas não funcionantes. Markesis et al. (2009) descreveram a ocorrência rara da presença de zonas mortas cocleares quando o limiar absoluto é inferior a 70dBNA. Acreditamos numa desorganização geral da tonotopia coclear, que pode ter sido causada pela impregnação da cisplatina. 
Nossos pacientes com a presença de zonas irresponsivas cocleares tem menor seletividade de frequências, como descrito por Moore (2001) com o termo off place ou off frequency listening. Quando a vibração da membrana basilar for forte o suficiente para promover a dispersão da onda sonora, de modo que um tom puro que produza um pico de vibração na região irresponsiva, poderá ser detectado em outro lugar na cóclea, onde as células ciliadas internas e/ou os neurônios adjacentes estejam saudáveis e funcionando com mais eficiência, gerando distorção, pois não é o local correto da detecção do som. Na presença de positividade do teste TEN, a diferença entre o limiar auditivo absoluto e o limiar auditivo mascarado foi superior a 10 $\mathrm{dB}$. Em algumas frequências, os limiares mascarados tornaram-se ausentes (Tabela 2). A presença das emissões otoacústicas tanto transientes evocadas quanto produto de distorção em dois pacientes distintos, cada qual em uma orelha corrobora a idéia das células ciliadas externas estarem presentes.

A ototoxicidade pela cisplatina afeta o órgão de Corti como um todo (Mukherjea \& Rybak, 2011, Breglio et al., 2017) podendo causar mau funcionamento da resposta tonotópica coclear de uma forma generalizada. De qualquer forma foi possível constatar que apesar das células ciliadas estarem presentes, não estão cumprindo o seu papel de transformar o estímulo mecânico em pulso elétrico na região correta.

Outro motivo pelo qual tenhamos encontrado grande número de zonas irresponsivas cocleares seja a aplicação do teste TEN em passos de $5 \mathrm{~dB}$. Moore (2003), sugere a aplicação em passos de 2 em 2 dB, por tornar o teste mais sensível, Cairns et al. (2007) também concluíram que esta técnica é mais precisa. Nós aplicamos o teste em passos de $5 \mathrm{~dB}$, por acreditarmos que seja mais factível, menos cansativo e mais rápido. A Associação Britânica de Audiologia também sugere passos de $5 \mathrm{~dB}$ como descrito em Moore et al. (2006). Nossos resultados estão em acordo com Hornsby et al. (2009), que aplicaram também o teste em passos de $5 \mathrm{~dB}$ por acreditarem que a especificidade seria maior, na medida em que encontrariam menor número de falsos positivos. Eles encontraram $84 \%$ de orelhas com teste TEN positivo, 
sendo $39 \%$ em limiares absolutos inferiores a $60 \mathrm{~dB}$ e descreveram a ocorrência de positividade no teste em limiares entre 20 e $30 \mathrm{~dB}$.

Diferentemente da literatura que descreve a presença de zonas mortas cocleares somente a partir de limiares superirores a $70 \mathrm{dNBA}$, nós encontramos sua presença independentemente do limiar. Acreditamos que o critério de diferença de $10 \mathrm{~dB}$ entre o limiar absoluto e o limiar mascarado deva ser utilizado e interpretado como presença de zonas com células irresponsivas, sobretudo em limiares absolutos inferiores a 70dBNA.

Também é possível que a positividade no teste TEN tenha ocorrido por uma desorganização da tonotopia cortical. Quando há uma perda ou uma alteração importante dos receptores periféricos (células ciliadas) também ocorrem mudanças nos mapas sensoriais corticais (Chen \& Yuan, 2015). Os neurônios que inervam estas regiões se tornam responsivos a estímulos em regiões que estão preservadas vizinhas à região lesionada (Phillibert et al., 2005). Thai-Van et al. (2003) descreveram que a perda auditiva em rampa acentuada com a presença de zonas mortas cocleares é condição para a ocorrência da plasticidade e da reorganização auditiva central. Toda nossa casuística foi composta por inidvíduos com perda auditiva em rampa.

Chen \& Yuan (2015) relataram que a privação aural pode distorcer mapas tonotópicos, quebrar a integração binaural, reorganizar a rede neural e mudar a transmissão no córtex auditivo primário. Thai-Van et al. (2010) observaram alteração significante nos mapas corticais em pacientes com perda auditiva em rampa descendente após 1 mês do uso das próteses auditivas, sugerindo que a amplificação pode reverter a privação sensorial fazendo com que neurônios voltem a sua função normal e permitindo que o mapa tonotópico cortical recupere o mesmo padrão de representação de pacientes normo ouvintes.

Syka (2002), descreveu que esta desorganização pode ocorrer em curto espaço de tempo após ototoxicidade, cerca de 60 dias. Eggermont (2017) referiu um tempo de 35 a 81 dias após lesão periférica em estudo experimental. Mukherjea \& Rybak (2011) descreveram que a ototoxicidade pela cisplatina 
pode ocorrer em até 72 horas após sua administração, indicando que a reorganização ocorre rapidamente. É possível que a cisplatina tenha causado desorganização na tonotopia coclear. Para analisar o efeito da privação sensorial sobre a reorganização cortical coletamos o tempo entre o fim do tratamento e a avaliação audiológica que variou de 2 a 228 meses (Tabela 1).

Acreditamos que a desorganização da tonotopia coclear, a presença de zonas cocleares irresponsivas, ou seja a falta do aporte sensorial, associado a um mapeamento tonotópico cortical falho, prejudicaram a compreensão de fala. O longo tempo de privação sensorial ao qual a maioria dos nossos pacientes foram expostos pode também ter contribuido. Alguns pacientes passaram 16 anos convivendo com a perda auditiva antes de iniciar o processo de adaptação com próteses auditivas.

Com relação aos limiares auditivos, foi possível observar melhora com o uso das próteses auditivas com diferença estatísticamente significante nas frequências a partir de $1 \mathrm{kHz}$, (Tabela 3) sem diferença estatística entre a programação com e sem limitação de frequências (Tabelas 4 e 5). Foi possível observar que na frequência de $8 \mathrm{kHz}$, apesar da melhora com próteses auditivas, ainda assim o limiar não permite o acesso aos sons de fala (Tabela 3). Ching et al. (1998) relataram que a necessidade de fornecer maior nível de pressão sonora em pacientes com maior grau de perda auditiva, pode causar distorção na amplificação e deste modo a contribuição da audibilidade para a melhora da inteligibilidade de fala pode ser negativa. Simpson et al., (2005) relataram que a não melhora na compreensão de fala em 10 pacientes com e sem zonas mortas pode ser pela falta de amplificação adequada em frequências altas. Hornsby et al. (2006) descreveram a dificuldade em fornecer amplificação necessária em frequências acima de $3 \mathrm{kHz}$ para tornar sons audíveis em pacientes com perda auditiva em rampa acentuada.

Em nosso estudo conseguimos melhora da audibilidade, permitindo acesso aos sons de fala na maior parte das frequências do audiograma (Tabelas 4 e 5). Salorio-Corbetto et al. (2017) relataram que o uso de próteses auditivas com limitação de frequências aumentou a quantidade de frequências 
audíveis. No entanto, em nosso estudo, isto não contribuiu para a melhora da compreensão de fala. A tabela 6 mostra que não houve melhora da porcentagem de acertos nas condições com e sem próteses auditivas no reconhecimento de frases no silêncio e no ruído. Também foi possível observar que mesmo com o uso de próteses auditivas, a variação da porcentagem do reconhecimento de mossílabos no ruído variou entre 0\% e 68\% (Tabelas 7 e 8) independente da programação. De fato, Einarsson et al. (2010) descreveram as dificuldades impostas por perdas auditivas por ototoxicidade após uso de derivados da platina, inclusive após longo prazo, pois a perda das células ciliadas leva à inabilidade coclear de diferenciar fala no ruído.

Gifford et al. (2007) avaliando 10 pacientes, encontraram $48 \%$ de reconhecimento de monossílabos no silêncio em pacientes com perda auditiva em rampa com o uso de próteses auditivas com limitação de frequências, no entanto os testes de reconhecimento de fala foram realizados a 70dBNA, em nosso estudo os testes foram realizados a 60dBNA. Einarsson et al. (2010) descreveram valores de reconhecimento de monossílabos, na melhor orelha de $91,7 \%$ no silêncio e $32,8 \%$ no ruído em seis adolescentes após tratamento oncológico. Zhang et al., 2014 encontraram 32 \% de reconhecimento de monossílabos no silêncio em pacientes com zona morta coclear fazendo uso de prótese auditiva com limitação de frequências. Em nossa casuística encontramos valores de reconhecimento de monossílabos no silêncio de $72 \%$ com o uso da limitação de frequências e de $64 \%$ sem o uso. No ruído encontramos valores de 56\% com limitação de frequências e 52\% sem limitação de frequências (Tabela 6), mostrando a dificuldade que estes pacientes apresentam em compreender a fala na presença de ruído. Acreditamos que nossos pacientes tenham apresentado valores piores no silêncio pela presença das zonas mortas ou irresponsivas cocleares e pelo tempo de privação sensorial.

Todos os pacientes preferiram a programação com limitação de frequências acionado (Tabela 12) de fato, apesar de não termos encontrado valores estatisticamente significantes, foi possível observar valores no reconhecimento de fala ligeiramente melhores com o uso deste recurso. As 
tabelas 7 e 8 mostram valores de reconhecimento de monossílabos, para a orelha direita de 56\% com limitação de frequências acionada e 44\% sem, e para a orelha esquerda valores de $52 \%$ com limitação de frequências e $44 \%$ sem. Alexander et al. (2014) observaram melhora na percepção de fonemas fricativos com o uso limitação de frequências acionado em pacientes com perda auditiva em frequências altas. Marchesin e lório (2015) descreveram melhores escores na detecção de consoantes.

Outros autores são favoráveis à amplificação estendida a todas as frequências. Simpson et al. (2005) descreveram melhor reconhecimento de fonemas fricativos com aumento da largura da banda de amplificação. Hornsby et al. (2006) sugeriram que a configuração da perda auditiva não deve limitar o uso da amplificação nas frequências altas. Cox et al. (2011) relataram que fornecer ganho extra de $32 \mathrm{~dB}$ na frequência de $4 \mathrm{kHz}$ provou ser favorável na melhora do reconhecimento de fala. Cox et al. (2012) concluíram que deve-se fornecer amplificação estendida mesmo a pacientes com zona morta coclear pois eles se beneficiaram de pistas acústicas fornecidas por esta amplificação. Hornsby et al. (2011) sugeriram oferecer amplificação em maior quantidade de bandas e frequências possível, independentemente do grau e da configuração das perdas. Brennan et al. (2014) relatam que os pacientes preferiram ter maior acesso às informações vindas das frequências altas. Pepler et al. (2016) encontraram média dos benefícios de 6\% nos pacientes com zona morta coclear e 13\% em pacientes sem zona morta coclear $(p=0,003)$ e não encontraram evidências que suportem a limitação da amplificação de frequências altas.

Em nosso estudo não encontramos diferença estatísticamente significante nos testes de reconhecimento de fala tanto no silêncio como no ruído em ambas as programações das próteses auditivas (Tabelas 6, 7 e 8). É possível que isso tenha acontecido pois todos os nossos pacientes tinham presença de zonas irresponsivas ou mortas cocleares em todas as frequências. Observamos melhora na audibilidade com próteses quando comparados a sem próteses auditivas, mas ainda assim, sua dificuldade de compreender a fala no ruido permaneceu. O funcionamento do sistema eferente olivococlear medial 
também pode ter sido afetado, de modo que a inibição da contração rápida das células ciliadas externas não esteja sendo efetivamente realizado, prejudicando a captação do sinal auditivo na presença de ruído de fundo, dificultando a discriminação da mensagem e prejudicando o desempenho dos pacientes na presença de ruído. Cox et al. (2011) descreveram que pacientes com zona morta coclear têm menor habilidade em explorar pistas acústicas da fala em frequências altas e este também é um possível motivo pelo qual não tenhamos encontrado melhora na comprensão de fala.

Foi possível notar, através dos dados do datalogging (Tabela 11), o baixo número de horas de uso, sugerindo um uso não efetivo das próteses auditivas. É possível que a presença do molde, apesar das adequações individuais quanto à ventilação, provoque algum grau oclusão nas baixas frequências, que estão preservadas, causando alguma dificuldade na detecção e compreensão destes sons. Além disso, a falta de contribuição das próteses auditivas na compreensão de fala em qualquer das programações, em nossos pacientes, justifica a baixa adesão ao uso do dispositivo. É possivel compreender o uso não efetivo pois apesar de reestabelecermos audibilidade sem desconforto, não conseguimos atingir melhora na compreensão de fala, melhora na comunicação, o que pode ter gerado frustração ou desânimo. Sabe-se que altos índices percentuais de reconhecimento de fala estão relacionados com maior aceitação do uso de prótese auditiva. Eguti (2002) demonstrou que tal aceitação ocorreu em 94,1\% dos pacientes sem zonas mortas em comparação com apenas $21,4 \%$ em pacientes diagnosticados com presença de zonas mortas cocleares.

Soma-se o fato de que nossos pacientes também possuem outras limitações e dificuldades, por vezes fazendo uso de outras próteses como ocular ou de fêmur. Acreditamos que eles tenham outros desafios e dificuldades, inclusive a estética, além de estarem sempre preocupados com uma recaída ou o aparecimento de metástase. De fato, Ciesla et al. (2016) afirmaram que pacientes com surdez parcial são uma população muito específica que enfrenta desafios psicológicos, sociais e emocionais 
relacionados a sua dificuldade auditiva. Acreditamos que esses fatores possam ser ainda mais evidentes no paciente oncológico.

Infelizmente pouquíssimos pacientes voltaram para a verificação das características eletroacústicas das próteses auditivas. Uma das grandes falhas no acompanhamento destes pacientes ocorreu pela dificuldade no deslocamento dos mesmos de uma instituição à outra. A maioria de nossa amostra era composta por pacientes SUS, seis dos oito pacientes. Um deles portador de osteossarcoma de fêmur e morador do interior de São Paulo, apresentava grande dificuldade em comparecer às consultas. Os dois pacientes mais idosos faleceram durante a realização do trabalho. Os demais pacientes, estavavam inseridos no mercado de trabalho e não podiam faltar ao trabalho para comparecer ao atendimento, dando preferência ao acompanhamento oncológico.

Não encontramos diferença estatísticamente significante no escore do questionário HHIA/HHIE entre as condições sem prótese auditva, com prótese auditva com limitação de frequência e com prótese auditiva sem limitação de frequência (Tabela 9). Foi possível observar que a média dos escores mostrouse elevada em todas as condições, revelando uma restrição auditiva grave mesmo após a adaptação das próteses. Sem prótese auditiva, a média do escore foi de 69,75 pontos. Este valor melhora para 66 pontos com prótese auditiva mas sem limitação por frequência e melhora ainda mais para 65,25 pontos na condição com prótese auditiva e com limitação de frequências, mas ainda os pacientes permanecem auto reportando uma restrição auditiva grave, com escores acima de $42 \%$. É interessante notar que mesmo percebendo melhora na audibilidade os pacientes continuam auto reportando grande restrição auditiva no escore do questionário. Acreditamos que este resultado seja reflexo da não melhora no reconhecimento de fala, que acaba dificultando ou até mesmo restringindo as atividades diárias e a re-inserção social. Marchesin e lório (2015) também observaram que após protetização, a pontuação no questionário APHAB não refletiu a melhora observada clinicamente. Einarsson et al. (2011), observou melhora com média de 61,7\% menos dificuldades após o uso das próteses auditivas. Ciesla et al.,(2015) 
observaram um escore maior em todos os questionários aplicado no grupo de pacientes com perda auditiva com surdez parcial, indicando que apesar de todos terem audibilidade preservada nas frequências baixas, encontram desafios sociais e emocionais e precisam de atenção profissional. Acreditamos que o uso de questionários seja uma ferramenta importante que ajuda na tomada de decisões na prática clínica.

Da mesma forma não encontramos diferença estatisticamente significante entre a nota atribuída subjetivamente pelos pacientes entre as condições com e sem limitação de frequências. A tabela 10 mostra que a média da nota com limitação de frequência foi de 7,9 e de 7,1 sem limitação, sugerindo que os pacientes estavam satisfeitos com ambas as programações das próteses auditivas, ligeiramente mais satisfeitos com a programação com limitação de frequências. O que nos chama a atenção é que apesar de relatar grande dificuldade auditiva pelo resultado da pontução do questionário HHIA eles mostraram-se satisfeitos com as próteses auditivas, apesar também do uso não efetivo das mesmas. Por isso a alta nota atribuída a cada programação possa ser justificada pela melhora na audibilidade, embora não refletida no reconhecimento de fala.

Pelo fato de que pacientes com perda auditiva em rampa, e sobretudo com presença de zonas mortas cocleares apresentarem grande dificuldade de compreender a fala na presença de ruído, buscamos novas alternativas de reabilitação. Em nossa casuística, o reconhecimento de monossílabos no silêncio, mesmo com próteses auditivas, apresentou valores na orelha direita de $63 \%$ com limitação de frequências e 58,5\% sem limitação de frequências e na orelha esquerda apresentou valores de 58\% com limitação de frequências e $63,8 \%$ sem limitação de frequências, muito próximos aos valores sugeridos como critério para a candidatura ao implante coclear híbrido ou estimulação eletro-acústica (Tabela 14) proposto por Woodson et al., 2010.

Encontramos dois pacientes que seriam candidatos à realização da cirurgia para colocação do implante coclear híbrido ou estimulação eletroacústica em ambas as orelhas. Pois mesmo com ambas as programações, seu 
índice de reconhecimento de monossílabos foi inferior a 60\% em ambas as orelhas. Encontramos um paciente cujo resultado de reconhecimento de monossílabos foi inferior a $60 \%$ com o uso de limitação de frequências na orelha esquerda e sem o uso de limitação de frequências na orelha direita. Outro paciente que com limitação de frequências na orelha esquerda obteve índice de reconhecimento de monossílabos de 60\% e sem limitação de frequências de $80 \%$, sugerindo a importância do uso e do teste de todos os recursos disponíveis, pois isto pode mudar o desempenho do paciente e consequentemente a indicação à cirurgia (Tabela 14). É digno de nota que no ruído, todos os pacientes com esta configuração de perda auditiva e com a presença de zonas cocleares mortas ou irresponsivas têm maior dificuldade e seu desempenho piora consideravelmente. Encontramos alguns pacientes com $0 \%$ de reconhecimento de frases no ruído, assim como nos monossílabos. Como a literatura descreve a melhora no desempenho e a satisfação do uso com os implantes cocleares híbridos ou estimulação eletro-acústica, acreditamos que os critérios de indicação à cirurgia também devessem levar em consideração os resultados dos testes de reconhecimento de fala no ruído.

De acordo com a tabela 11, o maior valor de SSI (Speech Inteligibility Index, encontrado para sons com entrada de $65 \mathrm{~dB}$, foi de $55 \%$, confirmando os valores de reconhecimento de monossílabos inferior a 60\% que obtivemos em cabine. A literatura aponta melhora nos testes de percepção de fala após a cirugia. Erixon et al. (2015) descreveram que todos os pacientes submetidos a cirurgia estavam satisfeitos com sua performance após a cirurgia e que esta opção deve ser oferecida a pacientes com surdez parcial. Ryu et al., (2015) relataram melhora no reconhecimento de monossílabos de $22,6 \%$ para $78,6 \%$ e em dissílabos de 45,3\% para 86,6\%. Roland et al. (2016) consideraram o tratamento com o implante híbrido ou estimulação elétro-acústica como essencial para a melhora na compreensão de fala e com contribuição efetiva para a melhora na qualidade de vida. No entanto Guimarães et al. (2015) descreveram uma taxa de aproximadamente $25 \%$ de perda da audição residual após a cirurgia para colocação do implante coclear híbrido. Acreditamos que a opção pela não realização da cirurgia se deva por medo desta complicação. A 
tabela 13 mostra a boa audição residual que Ihes permite compreender bem a fala no silêncio, sobretudo quando recebem mais pistas acústicas, mesmo sem o uso de próteses auditivas. O valor do reconhecimento de frases no silêncio variou entre $80 \%$ a $100 \%$. Um paciente apresentou reconhecimento de monossílabos de 96\%. Acreditamos que o fato destes pacientes apresentarem limiares auditivos preservados até $1 \mathrm{kHz}$, que permite o acesso a pistas e entrada natural dos sons de baixa frequência, tenha contribuído para o bom desempenho sem próteses auditivas. Moerel et al. (2012) descreveram que a fala e a voz contem mais energia em frequências relativamente baixas, até 1 kHz. A possibilidade da perda total da audição lhes pareceu um fator impeditivo para realização da cirurgia.

Considerando-se o direcionamento da reabilitação auditiva nossos resultados sugerem uma desorganização generalizada da responsividade tonotópica do sistema auditivo após tratamento oncológico com cisplatina. As opções e dispositivos disponíveis devem ser estudados segundo a motivação e demanda do paciente, podendo abranger as próteses auditivas convencionais ou o implante coclear híbrido/estimulação eletro-acústica. 
7 CONCLUSÃO 


\section{Conclusão}

Os dados do presente trabalho permitiram-nos concluir que:

- Zonas irresponsivas ou mortas cocleares foram encontradas em todas as frequências avaliadas após o tratamento oncológico em perdas auditivas em rampa.

- A amplificação oferecida pelas próteses auditivas permitiu melhora da audibilidade que não se traduziu em melhora do reconhecimento de fala no silêncio e no ruído em pacientes oncológicos com perdas auditivas em rampa,

- Identificamos critério de indicação para a cirurgia com o implante híbrido ou estimulação eletro-acústica em 3 de 8 pacientes da amostra.

- Todos os pacientes preferiram a amplificação com o uso do recurso de limitação de frequências acionado. 
8 ANEXOS 


\section{Anexo A. Aprovação do CEP-FMUSP}

\section{FACULDADE DE MEDICINA DA UNIVERSIDADE DE SÃO PAULO - FMUSP

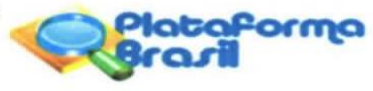

\section{PARECER CONSUBSTANCIADO DO CEP}

\section{DADOS DO PROJETO DE PESQUISA}

Título da Pesquisa: Condições da cóclea em pacientes oncológicos: o uso de recursos tecnológicos para definir a reabilitação auditiva de forma criteriosa e personalizada

Pesquisador: Maria Valéria Schmidt Goffi-Gomez

Area Temática:

Versão: 3

CAAE: 45553215.6 .0000 .0065

Instituição Proponente: Faculdade de Medicina da Universidade de São Paulo

Patrocinador Principal: Financiamento Próprio

\section{DADOS DO PARECER}

Número do Parecer: 1.222.109

Apresentação do Projeto:

Trata-se de pendência relativa à correção do endereço do CEP, no TCLE.

Não houve reparos à versão anteriormente apresentada do projeto.

Objetivo da Pesquisa:

O objetivo geral da pesquisa é identificar se o algoritmo de compressão de frequências beneficia as pessoas com perdas auditivas com zonas mortas cocleares.

Avaliação dos Riscos e Benefícios:

Conforme apresentação anterior, os pesquisadores assumem que os procedimentos não trazem desconforto ou dano.Avaliação finalizada.

Comentários e Consideraçōes sobre a Pesquisa:

Os pesquisadores realizaram todas correções indicadas.

Considerações sobre os Termos de apresentação obrigatória:

Conforme solicitação, o endereço do CEP foi corrigido.

Recomendações:

Não há.

Endereço: DOUTOR ARNALDO $25121^{\circ}$ andar sala 36 Bairro: PACAEMBU

UF: SP Município: SAO PAULO

Telefone: (11)3893-4401

CEP: $\quad 01.246-903$

E-mail: cep.fm@usp.br 


\section{FACULDADE DE MEDICINA DA UNIVERSIDADE DE SÃO PAULO - FMUSP}

Continuaçāo do Parecer: 1.222.109

Conclusões ou Pendências e Lista de Inadequações:

A pendência foi corrigida.

Considerações Finais a critério do CEP:

Este parecer foi elaborado baseado nos documentos abaixo relacionados:

\begin{tabular}{|c|c|c|c|c|}
\hline Tipo Documento & Arquivo & Postagem & Autor & Situação \\
\hline $\begin{array}{l}\text { TCLE / Termos de } \\
\text { Assentimento / } \\
\text { Justificativa de } \\
\text { Ausência }\end{array}$ & TCLEAgo2015.docx & $\begin{array}{c}25 / 08 / 2015 \\
12: 07: 20\end{array}$ & \begin{tabular}{|l|} 
Maria Valéria \\
Schmidt Goffi-Gomez
\end{tabular} & Aceito \\
\hline $\begin{array}{l}\text { Projeto Detalhado / } \\
\text { Brochura } \\
\text { Investigador }\end{array}$ & Projetodout.docx & $\begin{array}{c}25 / 08 / 2015 \\
12: 14: 04\end{array}$ & $\begin{array}{l}\text { Maria Valéria } \\
\text { Schmidt Goffi-Gomez }\end{array}$ & Aceito \\
\hline Folha de Rosto & FOLHA_DE_ROSTO.pdf & $\begin{array}{c}25 / 08 / 2015 \\
12: 12: 51\end{array}$ & $\begin{array}{l}\text { Maria Valéria } \\
\text { Schmidt Goffi-Gomez }\end{array}$ & Aceito \\
\hline $\begin{array}{l}\text { Informações Básicas } \\
\text { do Projeto }\end{array}$ & $\begin{array}{l}\text { PB_INFORMAÇŐES_BASICAS_DO_P } \\
\text { ROJETO 438088.pdf }\end{array}$ & $\begin{array}{c}25 / 08 / 2015 \\
12: 15: 28\end{array}$ & & Aceito \\
\hline
\end{tabular}

Situação do Parecer:

Aprovado

Necessita Apreciação da CONEP:

Não

SAO PAULO, 10 de Setembro de 2015

Assinado por:

Maria Aparecida Azevedo Kolke Folgueira

(Coordenador)

Endereço: DOUTOR ARNALDO $25121^{\circ}$ andar sala 36

Bairro: PACAEMBU

UF: SP Município: SAOPAULO

CEP: $\quad 01.246-903$

Telefone: (11)3893-4401

E-mail: cep.fm@usp.br 


\section{FACULDADE DE MEDICINA DA UNIVERSIDADE DE SÃO PAULO - FMUSP}

\section{PARECER CONSUBSTANCIADO DO CEP}

\section{DADOS DO PROJETO DE PESQUISA}

Título da Pesquisa: Condições da cóclea em pacientes oncológicos: o uso de recursos tecnológicos para definir a reabilitação auditiva de forma criteriosa e personalizada

Pesquisador: Maria Valéria Schmidt Goffi-Gomez

Área Temática:

Versão: 3

CAAE: 45553215.6 .0000 .0065

Instituiçăo Proponente: Faculdade de Medicina da Universidade de Săo Paulo

Patrocinador Principal: Financiamento Próprio

\section{DADOS DO PARECER}

Número do Parecer: 1.222 .109

Apresentação do Projeto:

Trata-se de pendência relativa à correção do endereço do CEP, no TCLE. Não houve reparos à versão anteriormente apresentada do projeto.

Objetivo da Pesquisa:

O objetivo geral da pesquisa é identificar se o algoritmo de compressão de frequências beneficia as pessoas com perdas auditivas com zonas mortas cocleares.

Avaliação dos Riscos e Benefícios:

Conforme apresentação anterior, os pesquisadores assumem que os procedimentos năo trazem desconforto ou dano.Avaliação finalizada.

Comentários e Consideraçōes sobre a Pesquisa:

Os pesquisadores realizaram todas correçöes indicadas.

Consideraçöes sobre os Termos de apresentação obrigatória:

Conforme solicitação, o endereço do CEP foi corrigido.

Recomendações:

Não há.

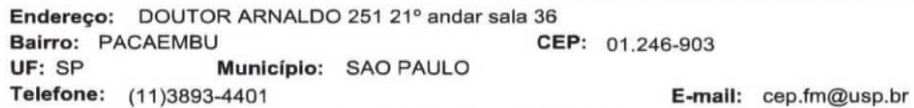




\section{Anexo B. Aprovação do CEP - A C Camargo Cancer Center}

A.C.Camargo

Cancer Center

\section{HOSPITAL A.C. CAMARGO CANCER CENTER}

\section{Peprofoforma}

\section{PARECER CONSUBSTANCIADO DO CEP}

Elaborado pela Instituição Coparticipante

\section{DADOS DO PROJETO DE PESQUISA}

Título da Pesquisa: Condições da cóclea em pacientes oncológicos: o uso de recursos tecnológicos para a reabilitação auditiva.

Pesquisador: Maria Valéria Schmidt Goffi Gomez

Área Temática:

Versão: 1

CAAE: 65086017.9 .3001 .5432

Instituição Proponente:Faculdade de Medicina da Universidade de Săo Paulo

Patrocinador Principal: Financiamento Próprio

\section{DADOS DO PARECER}

Número do Parecer: 2.018.576

\section{Apresentação do Projeto:}

Os pacientes que fazem uso de derivados da platina apresentam, como principal sintoma da ototoxicidade a diminuição da acuidade auditiva principalmente em em freqüências altas. A principal queixa é a dificuldade de compreender a fala em ambiente ruidoso. O conceito de "zonas mortas cocleares", proposto por Moore e Glasber em 1997, define que existem regiōes na cóclea nas quais as células ciliadas internas estão lesadas, inativas ou ausentes, e os neurônios que inervam essas regiões estariam inativos ou degenerados. Nessa situação, a amplificação dada pelas próteses auditivas convencionais não beneficiaria o paciente, considerando a falta do aporte sensorial coclear para a transdução do som. Este

estudo tem por objetivo identificar a frequência de ocorrência de perdas auditivas neurossensoriais com configuração descendente em rampa com presença de zonas mortas após o tratamento oncológico; a frequência de ocorrência de pacientes que se beneficiam com o uso de aparelhos auditivos convencionais prescritos para perdas em rampa; a frequência de ocorrência de pacientes que sejam candidatos à cirurgia para estimulação elétrica ou eletro-acústica com o implante coclear hibrido.Serão convidados a participar do estudo todos os pacientes acompanhados no Departamento de Audiologia do A.C. Camargo Cancer Center, ao final do tratamento oncológico com perda auditiva descendente em rampa, ou

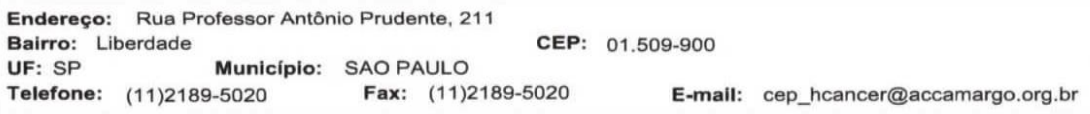


A.C.Camargo Cancer Center

\section{HOSPITAL A.C. CAMARGO CANCER CENTER}

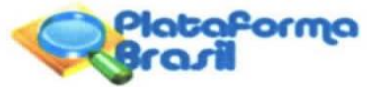

Continuaçăo do Parecer: 2.018.576

seja, limiares audiométricos iguais ou superiores a 70 dBNA a partir de $2000 \mathrm{~Hz}$. Serăo excluídos pacientes com mal formação de orelha externa,

orelha média ou orelha interna; tumores envolvendo o sistema auditivo, periférico ou central, cirurgia otológica prévia e pacientes incapazes de compreender ou realizar a avaliação proposta.Os procedimentos propostos envolvem o teste TEN (TEN - Threshold Equalizing Noise) para identificação de zonas mortas cocleares e o questionário Hearing Handicap Inventory for Adults HHIA, ou questionário Hearing Handicap Inventory

for Elderly HHIE, dependendo da idade do paciente, ambos adaptados ao português. Com a identificação da perda auditiva e a presença das zonas mortas cocleares, o paciente será convidado à adaptação e experiência domiciliar com próteses auditivas convencionais, considerando a prescrição do médico otorrinolaringologista. Serão testados dois programas, com e sem compressão de frequências, para experiência domiciliar durante pelo menos 15 dias cada um. Após o período de experiência com cada programação/dispositivo serão realizados testes que avaliem o benefício de cada programa incluindo audiometria em campo livre e provas de percepção de fala no silêncio e no ruído com $\mathrm{SNR}=0 \mathrm{~dB}$. Ao final dos testes de percepção de fala, o paciente definirá sua preferência através de uma escala análoga visual (VAS). A ordem de apresentaçăo dos programas com

esem a compressăo de frequências será randomizada (www.randomizer.org). Assim que o paciente seja capaz de perceber o benefício com o uso de próteses auditivas convencionais, ele poderá finalizar o processo de teste das próteses e a doação pelo Sistema Único de Saude. Caso o paciente não demonstre benefício com as próteses em nenhum dos programas, será proposta a avaliação e explicação do procedimento do implante coclear híbrido. Além da preferência do paciente, seräo analisados os limiares e o desempenho de reconhecimento de fala no silêncio e no ruído com os programas/dispositivos utilizados.

\section{Objetivo da Pesquisa:}

Identificar se o algoritmo de compressão de frequências beneficia as pessoas com perdas auditivas com zonas mortas cocleares.

Além disso, identificar:

a. A frequência de ocorrência de perdas auditivas neurossensoriais com configuração descendente em rampa com presença de zonas mortas após o tratamento oncológico;

b. A frequência de ocorrência de pacientes que se beneficiam com o uso de aparelhos auditivos convencionais prescritos para perdas em rampa;

c. A frequência de ocorrência de pacientes que tenham indicação à cirurgia para estimulação

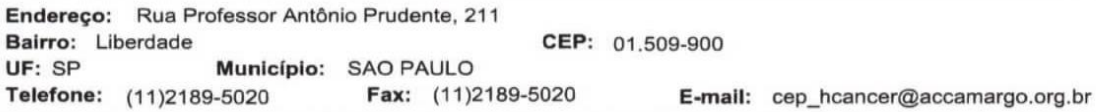

E-mail: cep_hcancer@accamargo.org.br 

A.C.Camargo
Cancer Center

\section{HOSPITAL A.C. CAMARGO CANCER CENTER}

Continuaçăo đo Parecer: 2.018.576

elétrica ou eletro-acústica com o implante hibrido.

Avaliação dos Riscos e Benefícios:

Consideramos que os benefícios da pesquisa proposta superam os riscos potenciais da mesma. Na avaliação de riscos e benefícios os pesquisadores reconhecerem o risco mínimo de quebra de confidencialidade relacionada a pesquisa, garantindo adotar medidas pertinentes que minimizem tal risco e protejam os participantes da pesquisa.

Comentários e Considerações sobre a Pesquisa:

Trata-se de pesquisa com relevância científica que contribuirá para a construção do conhecimento.

Considerações sobre os Termos de apresentação obrigatória:

Os termos de apresentação obrigatória estão apresentados de forma clara, respeitando a legislação em pesquisa vigente no país. O TCLE está apresentado de forma adequada.

Recomendações:

Não se aplica.

Conclusões ou Pendências e Lista de Inadequações:

Trata-se de pesquisa pertinente a área de conhecimento em questão. Não identificamos discrepância ética na metodologia e desenho da pesquisa que desabonem o desenvolvimento do estudo.

\section{Consideraçōes Finais a critério do CEP:}

Nota: Informações a respeito do andamento do referido projeto deverão ser encaminhadas ao CEP dentro de 06 meses a partir desta data em relatório (modelo CEP).

Este parecer foi elaborado baseado nos documentos abaixo relacionados:

\begin{tabular}{|l|l|c|c|c|}
\hline \multicolumn{1}{|c|}{ Tipo Documento } & \multicolumn{1}{|c|}{ Arquivo } & Postagem & Autor & Situação \\
\hline $\begin{array}{l}\text { Informações Básicas } \\
\text { do Projeto }\end{array}$ & PB_INFORMAÇŌES_BÁSICAS_DO_P & $22 / 02 / 2017$ & & Aceito \\
& ROJETO 859735.pdf & $10: 02: 32$ & \\
\hline
\end{tabular}

Endereço: Rua Professor Antônio Prudente, 211

Uairro: Liberdade $\quad$ Município: SAO PAULO

Telefone: (11)2189-5020 Fax: (11)2189-5020 E-mail: cep_hcancer@accamargo.org.br 
A.C.Camargo

Cancer Center
HOSPITAL A.C. CAMARGO CANCER CENTER

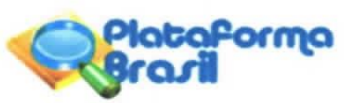

Continuaçẩo do Parecer: 2.018 .576

\begin{tabular}{|c|c|c|c|c|}
\hline Outros & Registro_Online0001.pdf & $\begin{array}{c}22 / 02 / 2017 \\
09: 55: 57\end{array}$ & $\begin{array}{l}\text { Maria Valéria } \\
\text { Schmidt Goffi Gomez }\end{array}$ & Aceito \\
\hline Orçamento & orcamento_2017.doc & $\begin{array}{c}22 / 02 / 2017 \\
09: 55: 13\end{array}$ & $\begin{array}{l}\text { Maria Valéria } \\
\text { Schmidt Goffi Gomez }\end{array}$ & Aceito \\
\hline Outros & Carta_CEP0001.pdf & $\begin{array}{c}22 / 02 / 2017 \\
09: 53: 12\end{array}$ & $\begin{array}{l}\text { Maria Valéria } \\
\text { Schmidt Goffi Gomez }\end{array}$ & Aceito \\
\hline $\begin{array}{l}\text { Projeto Detalhado / } \\
\text { Brochura } \\
\text { Investigador }\end{array}$ & Projeto.docx & $\begin{array}{c}22 / 02 / 2017 \\
09: 50: 24\end{array}$ & $\begin{array}{l}\text { Maria Valéria } \\
\text { Schmidt Goffi Gomez }\end{array}$ & Aceito \\
\hline $\begin{array}{l}\text { TCLE / Termos de } \\
\text { Assentimento / } \\
\text { Justificativa de } \\
\text { Ausência } \\
\end{array}$ & TCLE2_Jan2017.docx & $\begin{array}{c}22 / 02 / 2017 \\
09: 49: 37\end{array}$ & $\begin{array}{l}\text { Maria Valéria } \\
\text { Schmidt Goffi Gomez }\end{array}$ & Aceito \\
\hline $\begin{array}{l}\text { TCLE / Termos de } \\
\text { Assentimento / } \\
\text { Justificativa de } \\
\text { Ausência } \\
\end{array}$ & TCLE1_Jan2017.docx & $\begin{array}{c}22 / 02 / 2017 \\
09: 49: 04\end{array}$ & $\begin{array}{l}\text { Maria Valéria } \\
\text { Schmidt Goffi Gomez }\end{array}$ & Aceito \\
\hline Folha de Rosto & Folha_Rosto0001.pdf & $\begin{array}{c}22 / 02 / 2017 \\
09: 47: 30\end{array}$ & $\begin{array}{l}\text { Maria Valéria } \\
\text { Schmidt Goffi Gomez }\end{array}$ & Aceito \\
\hline
\end{tabular}

Situação do Parecer:

Aprovado

Necessita Apreciação da CONEP:

Não

SAO PAULO, 17 de Abril de 2017

\section{Assinado por:}

Sandra Caires Serrano

(Coordenador)

Endereço: Rua Professor Antônio Prudente, 211

Bairro: Liberdade

UF: SP

Telefone: (11)2189-5020

Fax: (11)2189-5020

CEP: $\quad 01.509-900$

E-mail: cep_hcancer@accamargo.org.br 


\title{
Anexo C - Termo de Consentimento Livre e Esclarecido \\ hOSPITAL DAS CLÍNICAS DA FACULDADE DE MEDICINA DA UNIVERSIDADE DE SÃO PAULO-HCFMUSP
}

\author{
A.C. CAMARGO CANCER CENTER \\ TERMO DE CONSENTIMENTO LIVRE E ESCLARECIDO \\ DADOS DA \\ PESQUISA
}

Título da pesquisa: Condições da cóclea em pacientes oncológicos: o uso de recursos tecnológicos para a reabilitação auditiva

Pesquisador principal: Dra M. Valéria Schmidt Goffi Gomez

Departamento/Instituto - Divisão de Clínica Otorrinolaringológica do HCFMUSP

\begin{abstract}
Essas informações estão sendo fornecidas para convidá-lo a participar, de forma voluntária, neste estudo, que pretende estudar quantos pacientes que utilizaram tratamento com derivados da platina têm perda de audição, com lesão das células sensoriais da cóclea (órgão da audição). Se você aceitar participar, isso poderá auxiliar o melhor conhecimento do envolvimento do sistema auditivo nas pessoas que fizeram esse tratamento.
\end{abstract}

Justificativa e objetivos do estudo

Os pacientes, que fazem tratamento do câncer com cisplatina ou similares, podem apresentar perda auditiva após o tratamento. Se sua perda é acentuada e o incomoda, gostaríamos de convidá-lo a participar deste estudo que vai identificar as condições de funcionamento da cóclea, onde estão as células sensoriais da audição. Quando as células sensoriais estão muito afetadas nos permite entender as dificuldades que você apresenta em compreender a fala, sobretudo em ambientes ruidosos.

Procedimentos que serão realizados e métodos que serão empregados

Os procedimentos a serem aplicados com você serão:

- Responder a um questionário chamado HHIE/HHIA (Hearing Handicap Inventory for Adults/Hearing Handicap Inventory for Elderly), para verificar o impacto da perda auditiva na sua vida, e leva, em média, 10 minutos.

- Avaliação Audiométrica, para verificar quanto você ouve. 
- Avaliação das emissões otoacústicas, para identificar se existem células sensoriais externas na cóclea. Será colocada uma espuma dentro do seu conduto auditivo externo. Durante dois minutos você escutará sons, mas você não precisa avisar nada, só ficar bem quieto.

- Teste TEN (Thresold Equalizing Noise) para verificar quanto você ouve na presença de ruído e se há a presença de zonas na cóclea onde as células sensoriais internas estejam ausentes ou funcionando mal. Você escutará os apitos ao mesmo tempo que o ruído, e deverá avisar quando perceber o apito.

Relação dos procedimentos rotineiros e como são realizados

Todos os exames são realizados na cabine de audiometria, e você escutará apitos. Deve avisar quando escutá-los.

A avaliação audiológica é constituída por exames com duração, em média, de 40 minutos. São simples, não invasivos, não causam dor, desconforto ou efeitos colaterais. O mínimo risco envolve eventual cansaço e sensação de ouvido tapado após a estimulação e regridem espontaneamente com o repouso acústico.

Benefícios esperados para o participante

Não há benefícios diretos aos participantes. Caso você aceite realizar os testes, somente no final do estudo poderemos concluir se as lesões que afetam de maneira mais importante as células sensoriais da cóclea se manifestam de forma diferente das demais.

Em qualquer etapa do estudo, você terá acesso aos profissionais responsáveis pela pesquisa para esclarecimento de eventuais dúvidas. O principal investigador é a Fga. Dr ${ }^{\mathrm{a}}$ Maria Valéria Schmidt Goffi Gomez, que pode ser encontrada no endereço Av. Dr. Enéas de Carvalho Aguiar, 155, 6ㅇandar, telefone (11) 26619491. Se você tiver alguma consideração ou dúvida sobre a ética da pesquisa, entre em contato com o Comitê de Ética em Pesquisa (CEP), Av. Dr. Arnaldo, 251, 21ํaㅁ andar, sala 36, Pacaembu, tel: 3893-4401, e-mail: cep.fm@usp.br

É garantida a liberdade de retirada de consentimento a qualquer momento e deixar de participar do estudo, sem qualquer prejuízo à continuidade de seu tratamento na Instituição. Seus dados serão sigilosos.

As informações obtidas serão analisadas em conjunto com as informações e os dados de outros pacientes, não sendo divulgada a identificação de nenhum paciente.

À medida que forem sendo gerados relatórios parciais dos resultados da pesquisa, você pode solicitar ser atualizado sobre eles.

Tanto seus dados pessoais, como os resultados dos testes desta pesquisa, somente serão divulgados para fins didáticos e científicos. O seu nome e qualquer característica sua que o identifique serão mantidos em sigilo.

Não há despesas pessoais para o participante em qualquer fase do estudo, incluindo exames e consultas. Também não há compensação financeira relacionada à sua participação. Você não abre mão de seus direitos de cidadão ao participar desta pesquisa.

\section{HOSPITAL DAS CLÍNICAS DA FACULDADE DE MEDICINA DA UNIVERSIDADE DE SÃO PAULO-HCFMUSP}

Acredito ter sido suficientemente informado a respeito das informações que li ou que foram lidas para mim, descrevendo o estudo "Condições da cóclea em pacientes oncológicos: o uso de recursos tecnológicos para a reabilitação auditiva", e receberei uma cópia deste documento assinado por mim e pelo pesquisador.

Eu discuti com a Dra ${ }^{\mathrm{a}}$ M. Valéria Schmidt Goffi Gomez e/ou com a Fga. Christiane Schultz sobre minha decisão em participar nesse estudo. Ficaram claros para mim quais são os propósitos do estudo, os procedimentos a serem realizados, seus desconfortos e riscos, as garantias de confidencialidade e de esclarecimentos permanentes. Ficou claro também que minha participação é isenta de despesas e que tenho garantia do acesso a tratamento hospitalar quando necessário. 
Concordo voluntariamente em participar deste estudo e poderei retirar o meu consentimento a qualquer momento, antes ou durante o mesmo, sem penalidades ou prejuízo ou perda de qualquer benefício que eu possa ter adquirido, ou no meu atendimento neste Serviço.

Este documento será assinado em duas vias, e você receberá uma das vias.

Assinatura do paciente/representante legal. Data:

Assinatura da testemunha. Data:

(Somente para o responsável do projeto)

Declaro que obtive, de forma apropriada e voluntária, o Consentimento Livre e Esclarecido deste paciente, ou representante legal, para a participação neste estudo.

Assinatura do responsável pelo estudo

Data: 
DADOS DE IDENTIFICAÇÃO (OU ETIQUETA INSTITUCIONAL DE IDENTIFICAÇÃO) DO PARTICIPANTE DA PESQUISA (OU RESPONSÁVEL LEGAL)

1.NOME:

DOCUMENTO DE IDENTIDADE №.

SEXO: $M \square F \square$

DATA NASCIMENTO:.........................

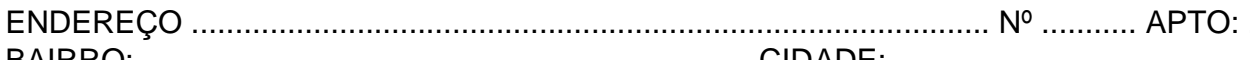

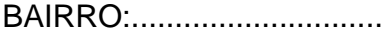

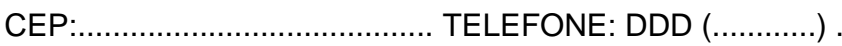

2.RESPONSÁVEL LEGAL:

NATUREZA (grau de parentesco, tutor, curador, etc.)

DOCUMENTO DE IDENTIDADE:

SEXO: $\mathrm{M} \square \mathrm{F} \square$

DATA NASCIMENTO.: .....................

ENDEREÇO:

№

APTO:

BAIRRO:

CIDADE:

CEP

TELEFONE: DDD

(..................

).


Anexo D - Termo de Consentimento Livre e Escalrecido HOSPITAL DAS CLÍNICAS DA FACULDADE DE MEDICINA DA UNIVERSIDADE DE SÃO PAULO-HCFMUSP

\author{
A.C. CAMARGO CANCER CENTER
}

TERMO DE CONSENTIMENTO LIVRE E ESCLARECIDO

Título da pesquisa: Condições da cóclea em pacientes oncológicos: 0 uso de recursos tecnológicos para a reabilitação auditiva Pesquisador principal: Drª M. Valéria Schmidt Goffi Gomez

Departamento/Instituto: Divisão de Clinica Otorrinolaringológica do HCFMUSP

Essas informações estão sendo fornecidas para convidá-lo a participar, de forma voluntária, neste estudo, que pretende avaliar as próteses auditivas convencionais, com novos recursos de transferência de ganho de frequências onde não existem células sensoriais funcionantes, e desta maneira proporcionar uma reabilitação auditiva individual e mais específica.

Seu benefício direto virá com o uso de próteses auditivas específicas para o seu caso, doadas pelo sistema único de saúde (SUS).

As pessoas que fazem tratamento do câncer com cisplatina ou similares podem apresentar perda auditiva após o tratamento. Se a perda é acentuada e incômoda, gostaríamos de convidá-lo a participar deste estudo que vai identificar as condições de funcionamento da audição, e das células sensoriais da audição. Quando as células sensoriais estão muito afetadas, podemos entender as dificuldades que você apresenta em compreender a fala, sobretudo em ambientes ruidosos. Para saber se as células sensoriais estão afetadas, aplicaremos um teste no qual você irá escutar apitos enquanto escuta um ruído.

Se identificar que as células sensoriais da sua audição estão muito afetadas, e você tiver interesse, nós o convidamos também a experimentar próteses auditivas no setor de próteses auditivas do Hospital das Clínicas da FMUSP, por um mês, e se lhe beneficiar, poderá receber a doação pelo sistema único de saúde (SUS).

Os procedimentos a serem aplicados com você serão:

1.1, Você deverá comparecer ao ambulatório do grupo de Implante Coclear do Hospital das Clínicas da FMUSP, na Av. Dr. Enéas de Carvalho Aguiar, 155, 6ํandar, sala 6, em três visitas separadas por 15 dias.

- Na primeira visita, para a adaptação e programação de próteses auditivas em ambas as orelhas.

- Na segunda visita, após 15 dias, serão realizados testes para a avaliação dos benefícios dessa programação e será programado outro ganho nas mesmas próteses.

- Na terceira visita, após novos 15 dias de experiência com a segunda programação, você deverá comparecer novamente ao HCFMUSP (Hospital das Clínicas da Faculdade de Medicina da Universidade de São Paulo) para a 
avaliação do desempenho com o novo programa e escolher aquele que mais o beneficiou.

A avaliação dos benefícios será realizada na cabine de audiometria, e você escutará apitos e deve avisar quando escutá-los. Depois você escutará frases e palavras apresentadas no silêncio e no ruído e deverá repeti-las. Primeiro, com o aparelho auditivo somente na orelha direita, e depois com o aparelho auditivo somente na orelha esquerda.

Descrição dos desconfortos e riscos esperados nos procedimentos

A avaliação audiológica é constituída por exames com duração, em média, de 30 a 40 minutos, simples, não invasivos, não causam dor, desconforto ou efeitos colaterais. O mínimo risco envolve eventual cansaço e sensação de ouvido tapado após a estimulação que regridem espontaneamente com o repouso acústico.

\section{Benefícios esperados para o participante}

Se você considerar que as próteses auditivas, com qualquer das programações pode Ihe beneficiar, poderá receber a doação pelo sistema único de saúde (SUS), no dia da última visita ao HCFMUSP (Hospital das Clínicas da Faculdade de Medicina da Universidade de São Paulo). Caso você não se beneficie das próteses auditivas convencionais, você receberá informações sobre as outras formas de reabilitação auditiva e poderá, se desejar, iniciar o processo de avaliação como candidato. Mas esse procedimento não fará parte desta pesquisa. Mesmo que você não aceite participar, seu tratamento no Hospital não será afetado.

Em qualquer etapa do estudo, você terá acesso aos profissionais responsáveis pela pesquisa para esclarecimento de eventuais dúvidas. O principal investigador é a Fga. Dra Maria Valéria Schmidt Goffi Gomez, que pode ser encontrada no endereço Av. Dr. Enéas de Carvalho Aguiar, 155, 6ํandar, telefone (11) 26619491. Se você tiver alguma consideração ou dúvida sobre a ética da pesquisa, entre em contato com o Comitê de Ética em Pesquisa (CEP), Av. Dr. Arnaldo, 251, 21ํandar, sala 36, Pacaembu, tel: 3893-4401, e-mail: cep.fm@usp.br

É garantida a liberdade da retirada de consentimento a qualquer momento e deixar de participar do estudo, sem qualquer prejuízo à continuidade de seu tratamento na Instituição. Seus dados serão sigilosos.

As informações obtidas serão analisadas em conjunto com as informações e os dados de outros pacientes, não sendo divulgada a identificação de nenhum paciente;

À medida que forem sendo gerados relatórios parciais dos resultados da pesquisa, você pode solicitar ser atualizado sobre eles.

Tanto seus dados pessoais, como os resultados dos testes desta pesquisa somente serão divulgados para fins didáticos e científicos. O seu nome e qualquer característica sua que o identifique serão mantidos em sigilo.

Não há despesas pessoais para o participante em qualquer fase do estudo, incluindo exames e consultas. Também não há compensação financeira relacionada à sua participação. Você não abre mão de seus direitos como cidadão ao participar desta pesquisa. 


\section{HOSPITAL DAS CLÍNICAS DA FACULDADE DE MEDICINA DA UNIVERSIDADE DE SÃO PAULO-HCFMUSP}

Acredito ter sido suficientemente informado a respeito das informações que li ou que foram lidas para mim, descrevendo o estudo "Condições da cóclea em pacientes oncológicos: o uso de recursos tecnológicos para a reabilitação auditiva", e receberei uma cópia deste documento assinado por mim e pelo pesquisador.

Eu discuti com a Dra ${ }^{\text {M }}$ M. Valéria Schmidt Goffi Gomez e/ou com a Fga. Christiane Schultz sobre minha decisão em participar nesse estudo. Ficaram claros para mim quais são os propósitos do estudo, os procedimentos a serem realizados, seus desconfortos e riscos, as garantias de confidencialidade e de esclarecimentos permanentes. Ficou claro também que minha participação é isenta de despesas e que tenho garantia do acesso a tratamento hospitalar quando necessário.

Concordo voluntariamente em participar deste estudo e poderei retirar o meu consentimento a qualquer momento, antes ou durante o mesmo, sem penalidades ou prejuízo ou perda de qualquer benefício que eu possa ter adquirido, ou no meu atendimento neste Serviço.

Este documento será assinado em duas vias, e você receberá uma das vias.

\begin{tabular}{l}
\hline Assinatura do paciente/representante legal \\
Data: \\
\hline Data: $\quad$ Assinatura da testemunha
\end{tabular}

(Somente para o responsável do projeto)

Declaro que obtive, de forma apropriada e voluntária, o Consentimento Livre e Esclarecido deste paciente, ou representante legal, para a participação neste estudo.

Assinatura do responsável pelo estudo

Data: 
DADOS DE IDENTIFICAÇÃO (OU ETIQUETA INSTITUCIONAL DE IDENTIFICAÇÃO) DO PARTICIPANTE DA PESQUISA (OU RESPONSÁVEL LEGAL)

1.NOME:

DOCUMENTO DE IDENTIDADE №.

SEXO: $\mathrm{M} \square \mathrm{F} \square$

DATA NASCIMENTO:........................

ENDEREÇO

№ ........... APTO:

BAIRRO

CEP:.

TELEFONE: DDD

CIDADE:

2.RESPONSÁVEL LEGAL:

NATUREZA (grau de parentesco, tutor, curador, etc.)

DOCUMENTO DE IDENTIDADE:

SEXO: $M \square F \square$

DATA NASCIMENTO.: ....................

ENDEREÇO:

№

APTO:

BAIRRO:

CIDADE:

CEP

TELEFONE: DDD

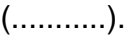

..........


Anexo E - HHIA

Nome:

Data de nascimento: Idade: Sexo:

Escolaridade:

\section{HEARING HANDICAP INVENTORY FOR ADULTS}

(Ventry \& Weinstein, 1982) (adaptação Almeida, 1998)

O questionário a seguir contém 25 perguntas. Você deverá escolher apenas uma resposta para cada pergunta, colocando um "(X)" naquela que julgar adequada. Algumas perguntas são parecidas, mas na realidade têm pequenas diferenças que permitem uma melhor avaliação das respostas. Não há resposta certa ou errada. Você deverá marcar aquela que julgar ser a mais adequada ao seu caso ou situação. Obrigada por sua participação!!

\begin{tabular}{|c|c|c|c|}
\hline & SIM & $\begin{array}{c}\text { ȦS } \\
\text { VEZZS }\end{array}$ & NÃO \\
\hline Você acha que ouve bem? & & & \\
\hline S1 - A dificuldade em ouvir faz você usar menos vezes o telefone do que gostaria? & & & \\
\hline $\begin{array}{l}\text { E2- A dificuldade em ouvir faz você se sentir constrangido ou sem jeito quando é apresentado a } \\
\text { pessoas desconhecidas? }\end{array}$ & & & \\
\hline S3- A dificuldade em ouvir faz você evitar grupos de pessoas? & & & \\
\hline E4- A dificuldade em ouvir deixa você irritado? & & & \\
\hline $\begin{array}{l}\text { E5- A dificuldade em ouvir faz você se sentir frustrado ou insatisfeito quando conversa com } \\
\text { pessoas da sua família? }\end{array}$ & & & \\
\hline S6- A diminuiçãp da audição causa dificuldades quando você vai a uma festa ou reunião social? & & & \\
\hline E7- A dificuldade em ouvir faz você se sentir frustrado aoo conversar com os colegas de trabalho? & & & \\
\hline S8- Você sente dificuldade em ouvir quando vai ao cinema ou teatro? & & & \\
\hline E9- Você se sente prejudicado ou diminuído devido a sua dificuldade em ouvir? & & & \\
\hline S10- A diminuição da audição Ihe causa dificuldades quando visita amigos, parentes ou vizinhos? & & & \\
\hline $\begin{array}{l}\text { S11- A dificuldade em ouvir faz com que você tenha problemas para ouvir/entender os colegas de } \\
\text { trabalho? }\end{array}$ & & & \\
\hline E12- A dificuldade em ouvir faz você ficar nervoso? & & & \\
\hline $\begin{array}{l}\text { S13- A dificuldade em ouvir faz você visitar amigos, parentes ou vizinhos menos vezes do que } \\
\text { gostaria? }\end{array}$ & & & \\
\hline E14- A dificuldade em ouvir faz você ter discussões ou brigas com a sua família? & & & \\
\hline S15- A diminuição da audição Ihe causa dificuldades para assistir TV ou ouvir rádio? & & & \\
\hline $\begin{array}{l}\text { S16- A dificuldade em ouvir faz com que você saia para fazer compras menos vezes do que } \\
\text { gostaria? }\end{array}$ & & & \\
\hline E17- A dificuldade em ouvir deixa você de alguma maneira chateado ou aborrecido? & & & \\
\hline E18- A dificuldade em ouvir faz você preferir ficar sozinho? & & & \\
\hline S19- A dificuldade em ouvir fez você querer conversar menos com as pessoas da família? & & & \\
\hline $\begin{array}{l}\text { S20- Você acha que a dificuldade em ouvir diminui ou limita de alguma forma sua vida pessoal ou } \\
\text { social? }\end{array}$ & & & \\
\hline $\begin{array}{l}\text { S21- A diminuição da audição Ihe causa dificuldades quando você está num restaurante com } \\
\text { familiares ou amigos? }\end{array}$ & & & \\
\hline E22- A dificuldade em ouvir faz você se sentir triste ou deprimido? & & & \\
\hline S23- A dificuldade em ouvir faz você assistir TV ou ouvir rádio menos vezes do que gostaria? & & & \\
\hline $\begin{array}{l}\text { E24- A dificuldade em ouvir faz você se sentir constrangido ou menos á vontade quando conversa } \\
\text { com amigos? }\end{array}$ & & & \\
\hline $\begin{array}{l}\text { E25- A dificuldade em ouvir faz você se sentir isolado ou "deixado de lado" num grupo de } \\
\text { pessoas? }\end{array}$ & & & \\
\hline
\end{tabular}




\section{Anexo F - HHIE}

Nome:

Data de nascimento: Idade: Sexo:

Escolaridade:

\section{HEARING HANDICAP INVENTORY FOR THE ELDERLY}

(Ventry \& Weinstein, 1982) (adaptação Wieselberg, 1997)

O questionário a seguir contém 25 perguntas. Você deverá escolher apenas uma resposta para cada pergunta, colocando um "(X)" naquela que julgar adequada. Algumas perguntas são parecidas, mas na realidade têm pequenas diferenças que permitem uma melhor avaliação das respostas. Não há resposta certa ou errada. Você deverá marcar aquela que julgar ser a mais adequada ao seu caso ou situação. Obrigada por sua participação!!

\begin{tabular}{|c|c|c|c|}
\hline & SIM & $\begin{array}{c}\text { ÀS } \\
\text { VEZES }\end{array}$ & NÃO \\
\hline \multicolumn{4}{|l|}{ Você acha que ouve bem? } \\
\hline \multicolumn{4}{|l|}{ S1 - A dificuldade em ouvir faz você usar menos vezes o telefone do que gostaria? } \\
\hline \multicolumn{4}{|l|}{$\begin{array}{l}\text { E2- A dificuldade em ouvir faz você se sentir constrangido ou sem jeito quando é apresentado } \\
\text { a pessoas desconhecidas? }\end{array}$} \\
\hline \multicolumn{4}{|l|}{ S3- A dificuldade em ouvir faz você evitar grupos de pessoas? } \\
\hline \multicolumn{4}{|l|}{ E4- A dificuldade em ouvir deixa você irritado? } \\
\hline \multicolumn{4}{|l|}{$\begin{array}{l}\text { E5- A dificuldade em ouvir faz você se sentir frustrado ou insatisfeito quando conversa com } \\
\text { pessoas da sua família? }\end{array}$} \\
\hline \multicolumn{4}{|l|}{$\begin{array}{l}\text { S6- A diminuição da audição causa dificuldades quando você vai a uma festa ou reunião } \\
\text { social? }\end{array}$} \\
\hline & & & \\
\hline \multicolumn{4}{|l|}{ S8- Você sente dificuldade em ouvir quando alguém fala cochichando? } \\
\hline \multicolumn{4}{|l|}{ E9- Você se sente prejudicado ou diminuído devido a sua dificuldade em ouvir? } \\
\hline \multicolumn{4}{|l|}{$\begin{array}{l}\text { S10- A diminuição da audição Ihe causa dificuldades quando visita amigos, parentes ou } \\
\text { vizinhos? }\end{array}$} \\
\hline \multicolumn{4}{|l|}{$\begin{array}{l}\text { S11- A dificuldade em ouvir faz com que você vá a serviços religiosos menos vezes que } \\
\text { gostaria? }\end{array}$} \\
\hline \multicolumn{4}{|l|}{ E12- A dificuldade em ouvir faz você ficar nervoso? } \\
\hline \multicolumn{4}{|l|}{$\begin{array}{l}\text { S13- A dificuldade em ouvir faz você visitar amigos, parentes ou vizinhos menos vezes do que } \\
\text { gostaria? }\end{array}$} \\
\hline \multicolumn{4}{|l|}{ E14- A dificuldade em ouvir faz você ter discussões ou brigas com a sua família? } \\
\hline \multicolumn{4}{|l|}{ S15- A diminuição da audição Ihe causa dificuldades para assistir TV ou ouvir rádio? } \\
\hline \multicolumn{4}{|l|}{$\begin{array}{l}\text { S16- A dificuldade em ouvir faz com que você saia para fazer compras menos vezes do que } \\
\text { gostaria? }\end{array}$} \\
\hline \multicolumn{4}{|l|}{ E17- A dificuldade em ouvir deixa você de alguma maneira chateado ou aborrecido? } \\
\hline \multicolumn{4}{|l|}{ E18- A dificuldade em ouvir faz você preferir ficar sozinho? } \\
\hline \multicolumn{4}{|l|}{ S19- A dificuldade em ouvir fez você querer conversar menos com as pessoas da família? } \\
\hline \multicolumn{4}{|l|}{$\begin{array}{l}\text { S20- Você acha que a dificuldade em ouvir diminui ou limita de alguma forma sua vida } \\
\text { pessoal ou social? }\end{array}$} \\
\hline \multicolumn{4}{|l|}{$\begin{array}{l}\text { S21- A diminuição da audição Ihe causa dificuldades quando você está num restaurante com } \\
\text { familiares ou amigos? }\end{array}$} \\
\hline \multicolumn{4}{|l|}{ E22- A dificuldade em ouvir faz você se sentir triste ou deprimido? } \\
\hline \multicolumn{4}{|l|}{ S23- A dificuldade em ouvir faz você assistir TV ou ouvir rádio menos vezes do que gostaria? } \\
\hline \multicolumn{4}{|l|}{$\begin{array}{l}\text { E24- A dificuldade em ouvir faz você se sentir constrangido ou menos á vontade quando } \\
\text { conversa com amigos? }\end{array}$} \\
\hline $\begin{array}{l}\text { E25- A dificuldade em ouvir faz você se sentir isolado ou "deixado de lado" num grupo de } \\
\text { pessoas? }\end{array}$ & & & \\
\hline
\end{tabular}


Anexo G - Lista de Frases

\begin{tabular}{|l|l|}
\hline É perigoso andar nesta rua & Meu filho está ouvindo música \\
\hline Não encontrei meu filho & Não paguei a conta do bar \\
\hline A chuva foi muito forte & A chuva inundou a rua \\
\hline Ela acabou de bater o carro & O aluno quer assistir ao filme \\
\hline Não posso dizer nada & Amanhã não posso almoçar \\
\hline Esqueci de levar a bolsa & Ela viaja em dezembro \\
\hline Os pães estavam quentes & Você teve muita sorte \\
\hline Os preços subiram na segunda & Sua mãe pôs o carro na garagem \\
\hline Elas já alugaram uma casa na praia & Ainda não pensei no que fazer \\
\hline Meu irmão viajou de manhã & Essa estrada é perigosa \\
\hline O avião já está atrasado & Encontrei seu irmão na rua \\
\hline O jantar da sua mãe estava bom & Parece que agora vai chover \\
\hline Esqueci de ir ao banco & Hoje é meu dia de folga \\
\hline O preço da roupa não subiu & Elas viajaram de avião \\
\hline Avisei o seu filho agora & Seu trabalho estará pronto amanhã \\
\hline Tem que esperar na fila & Esqueci de comprar os pães \\
\hline Elas foram almoçar mais tarde & Ouvi uma música linda \\
\hline Ganhei um carro azul lindo & Acabei de passar um cafezinho \\
\hline Ele não está com muita pressa & A bolsa está dentro do carro \\
\hline Não pude chegar na hora & Ainda não está bom \\
\hline
\end{tabular}


Anexo H - Lista de monossílabos

\begin{tabular}{|c|c|c|c|}
\hline D1 & D2 & D3 & D4 \\
& & & \\
\hline TIL & CHÁ & TIL & GAZ \\
\hline GAZ & DOR & GAZ & CÃO \\
\hline ROL & MIL & ROL & CAL \\
\hline PUS & TOM & PUS & BOI \\
\hline FAZ & ZUM & FAZ & NU \\
\hline GIM & MEL & GIM & FAZ \\
\hline RIR & TIL & RIR & GIM \\
\hline BOI & GIM & BOI & PUS \\
\hline VAI & DIL & VAI & SEIS \\
\hline MEL & NU & MEL & NHÁ \\
\hline NU & PUS & NU & MIL \\
\hline LHE & NHÁ & LHE & TEM \\
\hline CAL & SUL & CAL & ZUM \\
\hline MIL & GAZ & MIL & TIL \\
\hline TEM & ROL & TEM & LHE \\
\hline DIL & TEM & DIL & SUL \\
\hline DOR & FAZ & DOR & CHÁ \\
\hline CHÁ & LHE & CHÁ & ROL \\
\hline ZUM & BOI & ZUM & MEL \\
\hline NHA & CAL & NHÁ & DOR \\
\hline CÃO & RIR & CÃO & VAI \\
\hline TOM & CÃ̃ & TOM & DIL \\
\hline SEIS & LER & SEIS & TOM \\
\hline LER & VAI & LER & RIR \\
\hline SUL & SEIS & SUL & SEIS \\
\hline
\end{tabular}


Anexo I - Ficha técnica da prótese auditiva Naída III SP

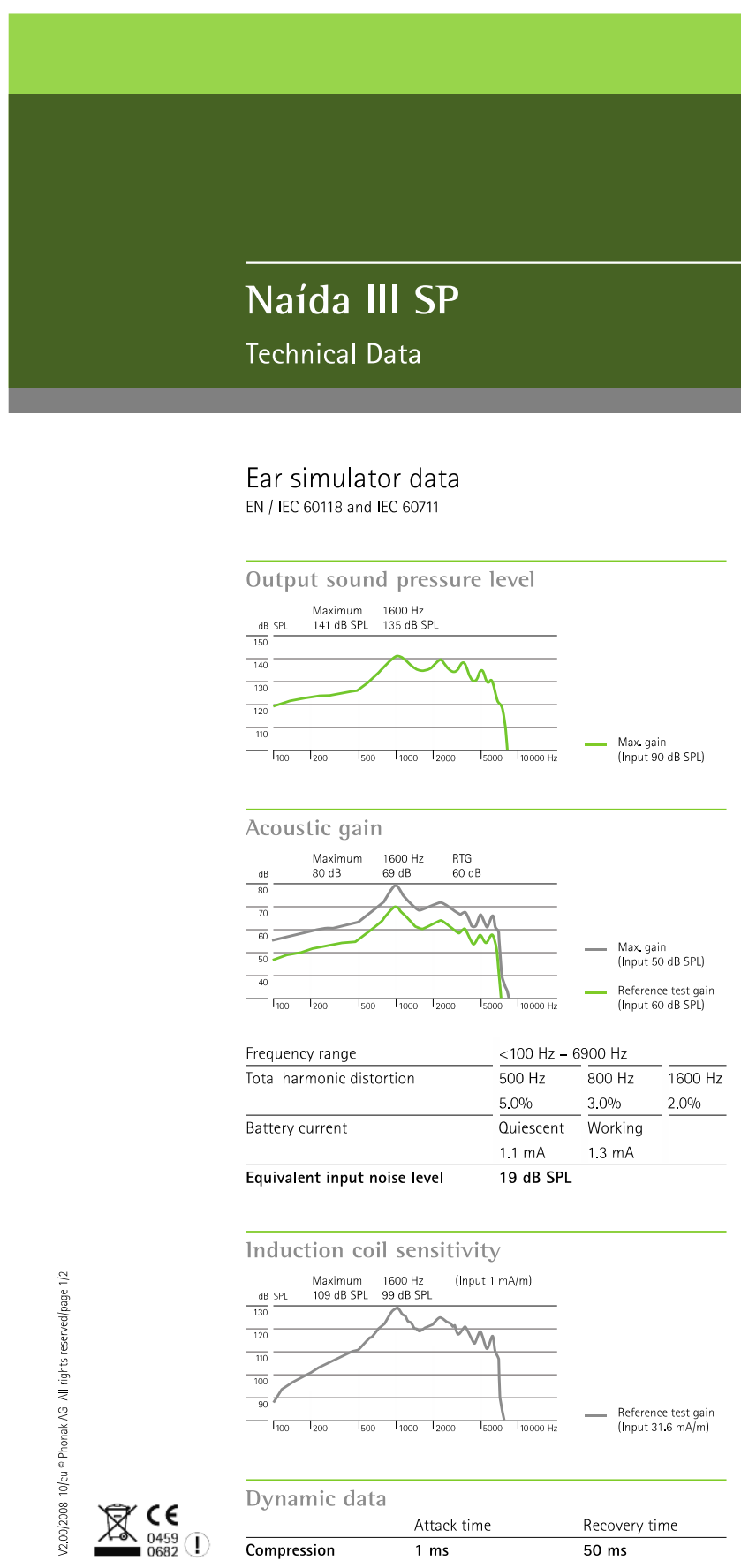

\section{Naída}

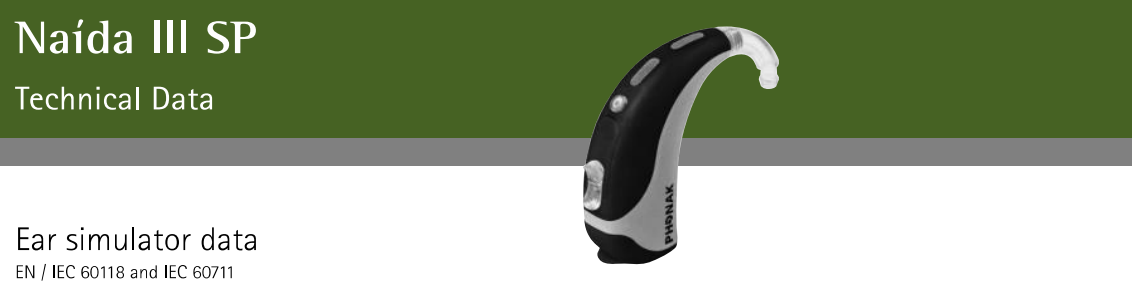

Water resistant SuperPower BTE with battery size 13 and omnidirectional microphone (for fitting range, product details, and available options, please see "Naída Product Information" or visit www.naida.phonak.com).

Warning to hearing care professionals:

This hearing instrument has an output sound pressure level that can exceed $132 \mathrm{~dB}$ SPL. Special care should be taken when fitting this instrument as there is a risk of impairing the residual hearing of the user.

Unless otherwise specified, all data obtained are measured with the hook type HE7 and PFG measurement settings.

Note: Measurements with pure tones of a digital hearing instrument can result in a wavy frequency response. This is an artifact resulting from the use of a narrowband input signal and does not reflect the actual performance with

naturally occuring broadband input signals.

\begin{tabular}{|c|c|c|c|}
\hline \multirow{2}{*}{$\begin{array}{l}\text { Frequency range } \\
\text { Total harmonic distortion }\end{array}$} & \multicolumn{2}{|c|}{$<100 \mathrm{~Hz}-6900 \mathrm{~Hz}$} & \multirow{3}{*}{$\begin{array}{l}1600 \mathrm{~Hz} \\
2.0 \%\end{array}$} \\
\hline & $500 \mathrm{~Hz}$ & $800 \mathrm{~Hz}$ & \\
\hline & $5.0 \%$ & $3.0 \%$ & \\
\hline \multirow[t]{2}{*}{ Battery current } & Quiescent & Working & \\
\hline & $1.1 \mathrm{~mA}$ & $1.3 \mathrm{~mA}$ & \\
\hline
\end{tabular}


Naída III SP

\section{$2 \mathrm{~cm}^{3}$ coupler data}

ANSI S3.22-1996

Output sound pressure level

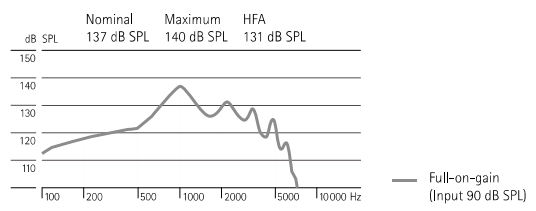

Acoustic gain

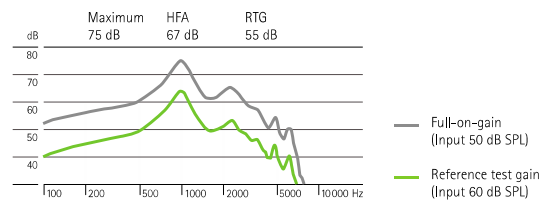

Frequency range

$\frac{<100 \mathrm{~Hz}-6400 \mathrm{~Hz}}{500 \mathrm{~Hz}} \frac{}{800 \mathrm{~Hz}} \frac{}{1600 \mathrm{~Hz}}$

\begin{tabular}{llll} 
& $4 \%$ & $2 \%$ & $1 \%$ \\
\hline Equivalent input noise level & $19 \mathrm{~dB} \mathrm{SPL}$
\end{tabular}

\section{Induction coil sensitivity}

\begin{tabular}{ccc} 
& HFA-SPLIV & TLS \\
$\mathrm{dB} S \mathrm{SPL}$ & $114 \mathrm{~dB} S \mathrm{SPL}$ & $-1 \mathrm{~dB}$ \\
\hline
\end{tabular}

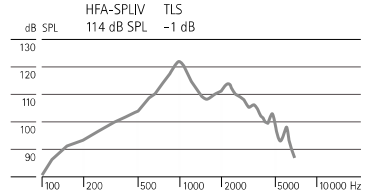

Dynamic data

Compression Attack tim $1 \mathrm{~ms}$

- Reference test gain

\begin{tabular}{ll}
$1 \mathrm{~ms}$ & Recovery time \\
\hline
\end{tabular}

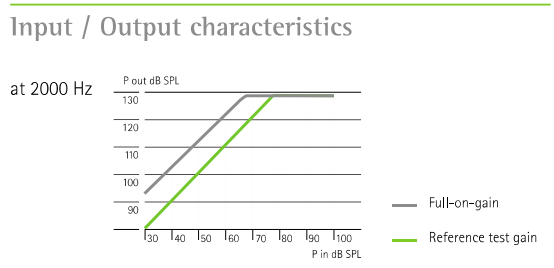


Anexo J- Exemplo de verificação das próteses auditivas
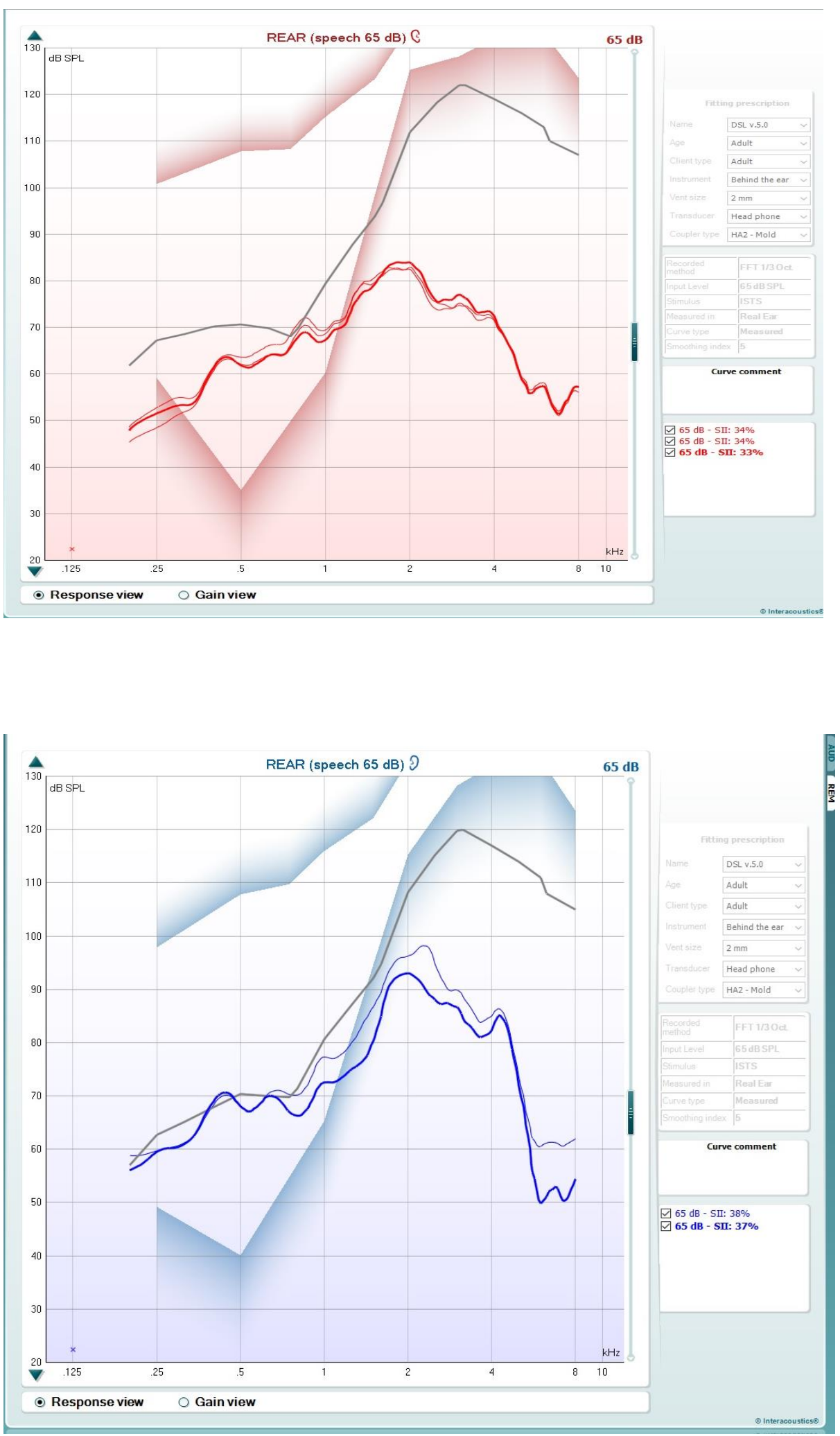
9 REFERÊNCIAS 


\section{REFERÊNCIAS}

Aazh H, Moore BC. Dead regions in the cochlea at $4 \mathrm{kHz}$ in elderly adults:

relation to absolute threshold, steepness of audiogram, and pure-tone average.

J Am Acad Audiol. 2007 Feb;18(2):97-106

Ahadi M, Milani M, Malayeri S. Prevalence of cochlear dead regions in moderate to severe sensorineural hearing impaired children. Int $\mathbf{J}$ Pediatr Otorhinolaryngol. 2015; 79(8):1362-5.

Alexander JM, Kopun JG, Stelmachowicz PG. Effects of frequency compression and frequency transposition on fricative and affricate perception in listeners with normal hearing and mild to moderate hearing loss. Ear Hear. 2014 Sep-Oct; 35(5):519-32.

Almeida K. Avaliação objetiva e subjetiva do benefício de próteses auditivas em adultos (Dissertação). São Paulo: Universidade Federal de São Paulo/Escola Paulista de Medicina; 1998.

Baer T, Moore BCJ, Kluk K. Effects of low pass filtering on the intelligibility of speech in noise for people with and without dead regions at high frequencies. $\mathbf{J}$ Acous Soc Am 2002; 112 (3): 1133-44.

Bertolini P, Lassalle M, Mercier G, Raquin MA, Izzi G, Corradini N, et al. Platinum compound-related ototoxicityin children: long- term follow-up reveals continuous worsening of hearing loss. J Pediatr Hematol Oncol. 2004;26:649--55. 
Breglio AM, Rusheen AE, Shide ED, Fernandez KA, Spielbauer KK, McLachlin $\mathrm{KM}$, Hall MD, Amable L, Cunningham LL. Cisplatin is retained in the cochlea indefinitely followingchemotherapy. Nat Commun, 2017 Nov 21;8(1):1654. doi: 10.1038/s41467-017-01837-1.

Brennan MA, McCreery R, Kopun J, Hoover B, Alexander J, Lewis $D$, Stelmachowicz PG. Paired comparisons of nonlinear frequency compression, extended bandwidth, and restricted bandwidth hearing-aid processing for children and adults with hearing loss. J Am Acad Audiol. 2014. Nov-Dec;25(10):983-98.

Breuel MLF, TG Sanchez, RF Bento. Vias auditivas eferentes e seu papel no sistema auditivo. Arq Int Otorrinolaringol, 2001; 5 (2): 62-67.

Cairns S, Frith R, Munro KJ, Moore BC. Repeteability of the TEN (HL) test for detecting cochlear dead regions. Int J Audiol. 2007; 46(10): 575-84.

Cieśla K, Lewandowska M, Skarzynski $\mathrm{H}$. Health-related quality of life and mental distress in patients with partial deafness: preliminary findings.

Eur Arch Otorhinolaryngol. 2016 Mar; 273(3): 767-76.

Chen Z, Yuan W.Central plasticity and dysfunction elicited by aural deprivation in the critical period. Front Neural Circuits. 2015 Jun 2;9:26.

Ching $T$, Dillon $H$, Byrne D. Speech recognition of hearing-impaired listeners. Predictions from audibility and the limited role of high-frequency amplification. $\mathbf{J}$ Acoust Soc Am 1998; 103: 1128-1140.

Choi JE, Chung WH, Cho YS, Hong SH, Moon IJ. Clinical Implication of the Threshold Equalizing Noise Test in Patients With Sudden Sensorineural Hearing Loss. Otol Neurotol. 2016 Dec; 37(10):1503-1509. 
Cox RM, Alexander GC, Johnson J, Rivera I. Cochlear dead regions in typical hearing aids candidates. Prevalence and implications for use of high frequency speech cues. Ear Hear. 2011; (32): 339-348.

Cox RM, Johnson JA, Alexander GC. Implications of high-frequency cochlear dead regions for fitting hearing aids to adults with mild to moderately severe hearing loss. Ear Hear. 2012 Sep-Oct; 33(5):573-87.

De Andrade AN, lório CM, Gil D. Speech recognition in individuals with sensorineural hearing loss. Braz J Otorhinolaryngol. 2016; 82(3): 334-340.

Eggermont JJ. Acquired hearing loss and brain plasticity. Hear Res. 2017 Jan;343:176-190. doi: 10.1016/j.heares.2016.05.008.

Eguti KY. Identificação das zonas mortas na cóclea utilizando a técnica de mascaramento com ruído branco [tese]. São Paulo: Universidade Federal de São Paulo; 2002.

Einarsson EJ, Petersen H, Wiebe T, Fransson PA, Grenner J. Long term hearing degeneration after platinum-based chematherapy in childhood. Int $\mathbf{J}$ Audiol 2010; 49, 765-771.

Einarsson EJ, Petersen H, Wiebe T, Fransson PA, Magnusson M, Möel C. Severe difficulties with word recognition in noise after platinum chemotherapy in childhood, and improvements with opeb-fitting hearing aids.. Int J Audiol 2011; $50,642-651$.

Erixon E, Rask-Andersen H. Hearing and Patient Satisfaction Among 19 Patients Who Received Implants Intended for Hybrid Hearing: A Two-Year Follow-Up. Ear Hear. 2015 Sep-Oct;36(5):e271-8.

Esfahani Monfared Z, Khosravi A, Safavi Naini A, Radmand G, Khodadad K. Analysis of Cisplatin-Induced Ototoxicity Risk Factors in Iranian Patients with 
Solid Tumors: a Cohort, Prospective and Single Institute Study. Asian Pac J

Cancer Prev. 2017 Mar 1;18(3):753-758.

Fraga F; Prates, LP; Marotta AM; Martinelli lorio MC. Frequency Lowering Algorithms for the Hearing Impaired. Intechopen. Speech Technologies. 2011; Cap 18. p. 361 - 384. doi: 10.5772/16331

Gifford RH, Dorman MF, Spahr AJ, McKarns SA. Effect of Digital Frequency Compression (DFC) on Speech Recognition in Candidates for Combined Electric and Acoustic Stimulation (EAS). J Speech Lang Hear Res. 2007 October ; 50(5): 1194-1202.

Glista D, Scollie M, Bagatto, Seewald L, Parsa V, Johnson A. Evaluation of nonlinear frequency compression: clinical outcomes. Int J Audiol. 2009; 48(9): 632-44.

Guimarães AC, Carvalho GM, Duarte AS, Bianchini WA, Sarasty AB, Gregorio MF, Zernotti ME, Sartorato EL, Castilho AM. Hearing preservation and cochlear implants according to inner ear approach: multicentric evaluation. Braz $\mathbf{J}$ Otorhinolaryngol. 2015 Mar-Apr;81(2):190-6.

Goffi-Gomez MVS, Guedes MC, Sant'Anna SBG, Peralta CGO, Tsuji RK, Castilho AM, Brito RV, Bento RF. Critérios de seleção e avaliação médica e audiológica dos candidatos ao implante coclear: Protocolo HCFMUSP. Arq Otorrinolaringol 2004; 7(3): 197-204.

Guiraud J, Besle J, Arnold L, Boyle P, Giard MH, Bertrand O, Norena A, Truy E, Collet $\mathrm{L}$. Evidence of a tonotopic organization of the auditory cortex in cochlear implant users. J Neurosci. 2007 Jul 18;27(29):7838-46. 
Gordo A, lório MCM. Zonas mortas na cóclea em frequências altas: implicações no processo de adaptação de prótese auditivas Rev. Bras. Otorrinolaringol, 2007; 73(3): 299-307.

Hall III JW, Chandler D. Tympanometry in clinical audiology. In: Katz J, editor. Handbook of clinical audiology. $4^{\text {th }}$ ed. Baltimore: William \& Wilkins; 1994. p. 283-99.

Hornsby BW, Ricketts TA. The effects of hearing loss on the contribution of high- and low-frequency speech information to speech understanding. II. Sloping hearing loss. J Acoust Soc Am. 2006 Mar; 119(3): 1752-63.

Hornsby BW, Benjamin WY, Dundas JA. Factors affecting outcomes on the TEN (SPL) test in adults with hearing loss. J Am Acad Audiol. 2009 Apr; 20(4): 251-63.

Hornsby BW, Johnson EE, Picou E. Effects of degree and configuration of hearing loss on the contribution of high and low frequency speech information to bilateral speech understanding Ear Hear. 2011 Sep-Oct; 32(5): 543-55.

Hyppolito MA, de Oliveira AA, Lessa RM, Rossato M. Amifostine otoprotection to cisplatin ototoxicity: a guinea pig study using otoacoustic emission distortion products (DPOEA) and scanning electron microscopy. Braz J Otorhinolaryngol. 2005 May-Jun; 71(3): 268-73.

Hyppolito MA, de Oliveira JA, Rossato M. Cisplatin ototoxicity and otoprotection with sodium salicylate. Eur Arch Otorhinolaryngol. 2006 Sep; 263(9): 798-803.

Izquierdo MA, Oliver DL, Malmierca MS. [Functional and activitydependent plasticity mechanisms in the adultand developing auditory brain]. Rev Neurol. 2009 Apr 16-30;48(8):421-9. 
Jacob RTS, Fernandes JC. lório MCM. Identificação de zonas mortas da cóclea por meio do Teste TEN. Rev. Bras. Otorrinolaringol 2006; 72 (5): 673-682.

Jereczek-Fossa BA, Zarowski A, Milani F, Orecchia R. Radiotherapy-induced ear toxicity. Cancer Treat Rev, 2003;29:417-30.

Jerger J. Clinical experience with impedance audiometry. Arch Otolaryngol, Oct; 92(4):311-24, 1970.

Katzenstein HM, Chang KW, Krailo M, et al. Amifostine does not prevent platinum-induced hearing loss associated with the treatment of children with hepatoblastoma: a report of the Intergroup Hepatoblastoma Study P9645 as a part of the Children's Oncology Group. Cancer 2009; 115:5828-35.

Kopelovich JC, Reiss LA, Oleson JJ, Lundt ES, Gantz BJ, Hansen MR. Risk factors for loss of ipsilateral residual hearing after Hybrid cochlear implantation. Otol Neurotol. 2014 Sep;35(8): 1403-8.

Kós Ml; Almeida K; Frota S; Hoshino ACH. Emissões otoacústicas produto de distorção em normo-ouvintes e em perdas auditivas neurossensoriais leve e moderada com os protocolos 65/55 dB NPS E 70/70 dB NPS. Rev. CEFAC 2009; 11 (3): São Paulo jul./set.

Kuk K.; Keenan D.; Auriemmo J; Korhonen P. Re-evaluating the efficacy of frequency transposition. The Asha Leader, 2009; 14 (1): 14-17. http://www.asha.org/Publications/leader/2009/090120/f090120b.htm, acessado em 25 de janeiro de 2015.

Landegger LD, Psaltis D, Stankovic KM. Human audiometric thresholds do not predict specifc celular damage in the inner ear. Hear Res 2016; 335: 83-93. 
Lee HY, Seo YM, Kim KA, Kang YS, Cho CS. Clinical application of the threshold equalizing noise test in patients with hearing loss of various etiologies: A preliminary study. J Audiol Otol. 2015 Apr; 19(1): 20-5.

Liberman PH, Schultz C, Goffi MV, et al. Auditory effects after organ preservation protocol for laryngeal/hypopharyngeal carcinomas. Arch Otolaryngol Head Neck Surg 2004; 130: 1265-8.

Liberman $\mathrm{PH}$. Avaliação auditiva em pacientes tratados de câncer na infância. São Paulo; 2005. [Dissertação de Mestrado-Fundação Antônio Prudente].

Linksey ME, Johnstone PA. Radiation tolerance of normal temporal bone structures: implication for gamma knife stereotactic surgery. Int J Rariat Oncol Biol Phys 2003:57:196-200.

Magalhaes ATM, Goffi-Gomez MVS. Speech Discrimination Index in Presbycusis. Intl. Arch. Otorhinolaryngol. 2007; 11: 169-174.

Marchesin VC, lório MC. Study of the long-term effects of frequency compression by behavioral verbal tests in adults. Codas. 2015 Jan-Feb; 27(1): 37-43.

Markessis E, Nasr-Addine H, Colin C, Hoonhorst I, Collet G, Deltenre P, Munro $\mathrm{KJ}$, Moore BC. Effect of presentation level on diagnosis of dead regions using the threshold equalizing noise test. Int J Audiol. 2009 Feb;48(2):55-62

McDonald ME, Mattson J, Hill E. Profound sensorineural hearing loss after one cycle of intraperitoneal cisplatin in treatment of advanced ovarian cancer. Gynecol Oncol Rep. 2017 Mar 21;20:103-104. 
Moerel M, De Martino F, Formisano E. Processing of natural sounds in human auditory cortex: tonotopy, spectral tuning, and relation to voice sensitivity. J Neurosci. 2012 Oct 10;32(41):14205-16.

Moore, B.C.J. \& Glasberg, B.R. A model of loudness perception applied to cochlear hearing loss. Br J Audiol. 1998; 32:317-335.

Moore BC, Huss M, Vickers DA, Glasberg BR, Alcántara JI. A test for the diagnosis of dead regions in the cochlea. Br J Audiol 2000 Aug; 34(4): 205-24.

Moore BC. Dead regions in the cochlea: Diagnosis, perceptual consequences, and implications for the fitting of hearing aids. Trends Amplif 2001; 5(1): 1-34.

Moore BC, Killen T, Munro KJ. Application of the TEN test to impaired teenagers with severe-to-profound hearing loss. Int J Audiol. 2003 Dec; 42(8): 465-74.

Moore BC. Dead regions in the cochlea: conceptual foundations, diagnosis and clinical applications. Ear Hear 2004; 25(2): 98-116.

Moore BC, Glasberg BR, Stone MA. New version of the TEN test with calibrations in dB HL. Ear Hear 2004 Oct; 25(5): 478-87.

Moore BC, Vinay SN. Prevalence of dead regions in subjects with sensorineural hearing loss. Ear Hear. 2007 Apr; 28(2): 231-41.

Moore BC,Vinay SN. Enhanced discrimination of low-frequency sounds for subjects with high-frequency dead regions Brain. 2009 Feb; 132(Pt 2): 524-36. 
Mukherjea D, Rybak LP. Pharmacogenomics of cisplatin-induced ototoxicity. Pharmacogenomics 2011; 12: 1039-50.

Nitz A, Kontopantelis E, Bielack S, Koscielniak E, Klingebiel T, Langer T, Paulides M. Prospective evaluation of cisplatin- and carboplatin mediated ototoxicity in paediatric and adult soft tissue and osteosarcomapatients. Oncol Lett. 2013 Jan; 5(1): 311-315. Epub 2012 Oct 25.

Padilha C, Garcia MV, Costa MJ. O diagnóstico das zonas mortas cocleares e sua importância no processo de reabilitação auditiva. Rev. Bras Otorrinolaringol 2007; 73(4): 556-61.

Pepler A, Lewis K, Munro KJ. Adult hearing - aid users with cochlear dead reagions restricted to highfrequencies: Implications for amplification. Int $\mathbf{J}$ Audiol. 2016 6; 55(1): 20-9.

Philibert B, Collet L, Vesson JF, Veuillet E. The auditory acclimatization effect in sensorineural hearing-impaired listeners: evidence for functional plasticity.Hear Res. 2005 Jul;205(1-2):131-42.

Rademaker-Lakhai JM, Crul M, Zuur L, Baas P, Beijnen JH, Simis YJ, van Zandwijk N, Schellens JH. Relationship between cisplatin administration and the development of ototoxicity. J Clin Oncol. 2006 Feb 20;24(6):918-24.

Reiss LA, Turner CW, Karsten SA, Gantz BJ. Plasticity in human pitch perception induced by tonotopically mismatched electro-acoustic stimulation. Neuroscience. 2014 Jan 3;256:43-52.

Roland JT Jr, Gantz BJ, Waltzman SB, Parkinson AJ; Multicenter Clinical Trial Group. United States multicenter clinical trial of the cochlear nucleus hybrid implant system. Laryngoscope. 2016 Jan; 126(1): 175-81 
Ruggero MA, Rich NC, Recio A, Narayan SS, Robles L. Basilar-membrane responses to tones at the base of the chinchilla coclhea. J Acoust Soc Am 1997; 101(4): 2151-63.

Rybak LP. Ototoxicity and antineoplastic drugs. Otolaryngol Head Neck Surg 1999; 7: 239-43.

Rybak LP, Mukherjea D, Jajoo S, Ramkumar V. Cisplatin ototoxicity and protection: clinical and experimental studies. Tohoku J Exp Med 2009 Nov; 219(3): 177-86.

Ryu NG, Moon IJ, Chang YS, Kim BK, Chung WH, Cho YS, Hong SH. Cochlear Implantation for Profound Hearing Loss After Multimodal Treatment for Neuroblastoma in Children. Clin Exp Otorhinolaryngol. 2015 Dec; 8(4): 32934.

Salorio-Corbetto $M$, Baer $T$, Moore BC. Quality ratings of frequencycompressed speech by participants with extensive high-frequency dead regions in the cochlea. Int J Audiol. 2017 Feb; 56(2): 106-120.

Schreiner CE, Winer JA. Auditory cortex mapmaking: principles, projections, and plasticity. Neuron. 2007 Oct 25;56(2):356-65. Review

Schochat E. Percepção da fala em perdas auditivas neurossensoriais. In: Lichtig I, Carvallo RMM, editores. Audição: abordagens atuais. São Paulo: PróFono, 1997. p. 223-35.

Schuknecht HF. Presbycusis. Laryngoscope.1955; 65:402-419 APUD Moore BC. Dead regions in the cochlea: conceptual foundations, diagnosis and clinical applications. Ear Hear 2004; 25(2): 98-116.

Schuknecht HF \& Gacek MR. Cochlear pathology in presbycusis. The Annals 
of otology, Rhinology and Laryngology. 1993; 102; 1-16. APUD Moore BC. Dead regions in the cochlea: conceptual foundations, diagnosis and clinical applications. Ear Hear 2004; 25(2): 98-116.

Schultz C. Avaliação Auditiva em pacientes portadores de tumores de cabeça e pescoço submetidos a radioterapia. Dissertação de mestrado pela Fundação Antonio Prudente, 2007.

Schultz C, Goffi-Gomez, MV, Liberman PH, Carvalho AL. Report on hearing loss in oncology. Braz J Otorhinolaryngol. 2009;75(5):634-41

Schultz, C; Goffi-Gomez, MVS, Liberman, PHP; Pellizzon, AC; Carvalho AL. Hearing loss and complaint in patients with head and neck cancer treated with radiotherapy. Arch Otolaryngol Head Neck Surg 2010; 136(1): 1065-9.

Simpson A, McDermott HJ, Dowell RC. Benefits of audibility for listeners with severe high frequency hearing loss. Hear Res 2005; 210(1-2): 42-52.

Skarzynski H and Lorens A. Partial deafness treatment. Cochlear Implants Int. 2010 Jun;11 Suppl 1:29-41.

Skinner R. Best practice in assessing ototoxicity in children with cancer. Eur $\mathbf{J}$ Cancer 2004; 40: 2352-4.

Syka J. Plastic changes in the central auditory system after hearing loss, restoration of function, and during learning. Physiol Rev. 2002 Jul;82(3):601-36. Review.

Thai-Van H, Micheyl C, Moore BC, Collet L. Enhanced frquency discrimination near the hearing loss cut-off: a consequence of central auditory plasticity induced by cochlear damage? Brain 2003 Oct;126(Pt 10):2235-45. Epub 2003 Jul 7. 
Thai-Van H, Veuillet E, Norena A, Guiraud J, Collet L. Plasticity of tonotopic maps in humans: influence of hearing loss, hearingaids and cochlear implants. Acta Otolaryngol. 2010 Mar;130(3):333-7.

Troland LT. The psychophysiology of auditory qualities and attributes. Journal of General Psychology 1929; 2:28-58 APUD Moore BC. Dead regions in the cochlea: conceptual foundations, diagnosis and clinical applications. Ear Hear 2004; 25 (2): 98-116.

Tzanakakis M, Chimona T, Apazidou E., Giannakopoulou C, Velegrakis GA, Papadakis CE. Transitory evoked otoacoustic emission (TEOAE) and distortion product otoacoustic emission (DPOAE) outcomes from a three-stage newborn hearing screening protocol. Hippokratia. 2016; 20(2): 104-9.

Ventry IM, Weinstein BE. The hearing handicap inventory for the elderly: a new tool. Ear and Hearing. 1982; 3(3): 231-41

Vinay SN; Moore BC. Prevalence of dead regions in subjects with sensorineural hearing loss. Ear Hear 2007; 28(2):231-41.

Woodson EA, Reiss LA, Turner CW, Gfeller K, Gantz BJ. The Hybrid cochlear implant: a review. Adv Otorhinolaryngol. 2010;67:125-34.Epub 2009 Nov 25. Review.

Yantis PA. Pure air-conduction threshold testing. In: Katz J, editor. Handbook of clinical audiology. $4^{\text {th }}$ ed. Baltimore: William \& Wilkins; 1994. p. 97-108. 
Zhang T, Dorman MF, Gifford R, Moore BC. Cochlear dead regions constrain the benefit of combining acoustic stimulation with electric stimulation. Ear Hear. 2014 Jul-Aug; 35(4): 410-7.

Zuur CL,Simis YJ, Lansdaal PE, Hart AA, Schornagel JH, Dreschler WA, Rasch CR, Balm AJ. Ototoxicity in a randomized phase III trial of intra-arterial compared with intravenous cisplatin chemoradiation in patients with locally advanced head and neck cancer. J Clin Oncol. 2007 Aug 20; 25(24): 3759-65. 
APENNDICES 


\section{APÊNDICES}

Apêndice A. Limiares auditivos em campo livre, nas três situações avaliadas, sem próteses auditivas, com próteses auditivas com limitação de frequências e sem limitação de frequências.

\begin{tabular}{|c|c|c|c|c|c|c|c|c|c|c|c|c|c|c|c|c|}
\hline Pacientes & $\begin{array}{c}2,5 \mathrm{~Hz} \\
\mathrm{OD} \\
\end{array}$ & $\begin{array}{c}0,5 \mathrm{~Hz} \\
\mathrm{OD} \\
\end{array}$ & $\begin{array}{l}1 \mathrm{~Hz} \\
\mathrm{OD}\end{array}$ & $\begin{array}{l}2 \mathrm{~Hz} \\
\mathrm{OD}\end{array}$ & $\begin{array}{c}3 \mathrm{kHz} \\
\mathrm{OD}\end{array}$ & $\begin{array}{l}4 \mathrm{~Hz} \\
\mathrm{OD}\end{array}$ & $\begin{array}{c}6 \mathrm{kHz} \\
\mathrm{OD}\end{array}$ & $\begin{array}{c}8 \mathrm{kHz} \\
\mathrm{OD}\end{array}$ & $\begin{array}{c}2,5 \mathrm{~Hz} \\
\mathrm{OE}\end{array}$ & $\begin{array}{c}0,5 \mathrm{~Hz} \\
\mathrm{OE}\end{array}$ & $\begin{array}{l}1 \mathrm{~Hz} \\
\mathrm{OE}\end{array}$ & $\begin{array}{l}2 \mathrm{~Hz} \\
\mathrm{OE}\end{array}$ & $\begin{array}{c}3 \mathrm{~Hz} \\
\mathrm{OE}\end{array}$ & $\begin{array}{c}4 \mathrm{~Hz} \\
\mathrm{OE}\end{array}$ & $\begin{array}{c}6 \mathrm{~Hz} \\
\mathrm{OE}\end{array}$ & $\begin{array}{c}8 \mathrm{~Hz} \\
\mathrm{OE}\end{array}$ \\
\hline ID 1 & 20 & 20 & 20 & 70 & 85 & 90 & 95 & 95 & 15 & 15 & 10 & 70 & 90 & 90 & 105 & 100 \\
\hline Com LF & 30 & 30 & 30 & 45 & 45 & 60 & 55 & 80 & 20 & 25 & 35 & 60 & 60 & 60 & 65 & 65 \\
\hline Sem LF & 20 & 30 & 40 & 40 & 30 & 30 & 50 & 50 & 20 & 20 & 35 & 60 & 50 & 40 & 50 & 50 \\
\hline ID 2 & 20 & 20 & 20 & 70 & 85 & 90 & 90 & 85 & 30 & 30 & 20 & 70 & 100 & 120 & 110 & 100 \\
\hline Com LF & 30 & 30 & 20 & 50 & 40 & 80 & 70 & 70 & 25 & 25 & 25 & 45 & 50 & 70 & 75 & 75 \\
\hline Sem LF & 30 & 30 & 30 & 60 & 60 & 80 & 80 & 80 & 25 & 30 & 30 & 45 & 70 & 70 & 80 & 80 \\
\hline ID 3 & 35 & 40 & 50 & 85 & 100 & 105 & 110 & 100 & 35 & 35 & 50 & 85 & 110 & 110 & 110 & AUS \\
\hline Com LF & 35 & 40 & 50 & 70 & 70 & 70 & AUS & AUS & 30 & 30 & 45 & 75 & 90 & AUS & AUS & AUS \\
\hline Sem LF & 20 & 20 & 40 & 40 & 60 & AUS & AUS & AUS & 30 & 30 & 30 & 70 & 90 & AUS & AUS & AUS \\
\hline ID 4 & 10 & 10 & 15 & 50 & 60 & 80 & 100 & 100 & 15 & 25 & 20 & 70 & 80 & 100 & 110 & 105 \\
\hline Com LF & 20 & 25 & 20 & 20 & 30 & 40 & 50 & AUS & 15 & 20 & 25 & 25 & 40 & 60 & 95 & AUS \\
\hline Sem LF & 25 & 25 & 15 & 30 & 35 & 35 & 35 & 40 & 25 & 25 & 20 & 30 & 25 & 45 & 35 & 80 \\
\hline ID 5 & 15 & 10 & 20 & 85 & 90 & 85 & 100 & 95 & 25 & 25 & 15 & 80 & 80 & 85 & 105 & 105 \\
\hline Com LF & 10 & 20 & 20 & 50 & 50 & 55 & 65 & 80 & 10 & 10 & 50 & 65 & 60 & 70 & 65 & 80 \\
\hline Sem LF & 20 & 20 & 20 & 70 & 55 & 50 & 60 & 70 & 15 & 20 & 20 & 55 & 60 & 55 & 80 & AUS \\
\hline ID 6 & 25 & 25 & 20 & 70 & 80 & 90 & 100 & AUS & 20 & 25 & 30 & 80 & 90 & 100 & 100 & AUS \\
\hline Com LF & 20 & 20 & 30 & 55 & 55 & 60 & 50 & 50 & 25 & 25 & 25 & 60 & 60 & 70 & 80 & 85 \\
\hline Sem LF & 20 & 20 & 35 & 50 & 55 & 50 & 60 & 80 & 20 & 20 & 30 & 70 & 80 & 85 & 95 & AUS \\
\hline ID 7 & 10 & 10 & 20 & 65 & 80 & 85 & 90 & 95 & 10 & 10 & 30 & 70 & 75 & 80 & 100 & 100 \\
\hline Com LF & 15 & 10 & 25 & 35 & 45 & 50 & 50 & 80 & 10 & 10 & 30 & 30 & 30 & 40 & 40 & 80 \\
\hline Sem LF & 20 & 20 & 35 & 35 & 45 & 45 & 55 & AUS & 20 & 25 & 25 & 35 & 35 & 50 & 60 & AUS \\
\hline ID 8 & 25 & 15 & 30 & 100 & 100 & 105 & 110 & 110 & 30 & 15 & 45 & 90 & 105 & 110 & 110 & 100 \\
\hline Com LF & 25 & 20 & 25 & 30 & 35 & 50 & 55 & AUS & 30 & 20 & 30 & 40 & 40 & 60 & 50 & AUS \\
\hline Sem LF & 20 & 20 & 30 & 30 & 45 & 45 & 55 & AUS & 20 & 25 & 35 & 40 & 60 & 70 & 70 & AUS \\
\hline
\end{tabular}

Legenda: LF. Limitação de frequências. AUS. Ausentes 
APÊNDICES 